\title{
Improved Accuracy of S-Value Based Dosimetry: Transitioning from Cristy-Eckerman to ICRP Adult Phantoms
}

Shalini Subramanian ( $\sim$ ssubramanian@rapiddosimetry.com )

Radiopharmaceutical Imaging and Dosimetry, LLC https://orcid.org/0000-0001-7687-4853

Bin He

Radiopharmaceutical Imaging and Dosimetry, LLC

Eric Frey

Radiopharmaceutical Imaging and Dosimetry, LLC

Derek Jokisch

Francis Marion University

Wesley Bolch

University of Florida

Thorsten Poethko

Bayer AG

Hartwig Hennekes

Bayer AG

Adriaan Cleton

Bayer AG

Sandra Johanssen

Bayer AG

George Sgouros

Johns Hopkins University

Original research

Keywords: ICRP phantom, radiopharmaceutical dosimetry, Cristy-Eckerman phantom

Posted Date: March 22nd, 2021

DOI: https://doi.org/10.21203/rs.3.rs-320927/v1

License: (c) (i) This work is licensed under a Creative Commons Attribution 4.0 International License.

Read Full License 
1 Improved Accuracy of S-value based dosimetry: Transitioning from Cristy-Eckerman to ICRP adult phantoms

"Be not the first by whom the new are tried Nor yet the last to lay the old aside"

(Alexander Pope)

6 Shalini Subramanian ${ }^{1}$, Bin $\mathrm{He}^{1}$, Eric Frey ${ }^{1,2}$, Derek W. Jokisch ${ }^{3,4}$, Wesley Bolch ${ }^{5}$, Thorsten Poethko ${ }^{6}$, Hartwig Hennekes ${ }^{7}$, Adriaan Cleton $^{8}$, Sandra Johanssen ${ }^{6}$, George Sgouros ${ }^{1,2}$

$8{ }^{1}$ Radiopharmaceutical Imaging and Dosimetry, LLC (Rapid), Baltimore MD, USA, ${ }^{2}$ The Russell H.

9 Morgan Department of Radiology and Radiological Science, Johns Hopkins University, School of 10 Medicine, Baltimore MD, USA, ${ }^{3}$ Department of Physics and Engineering, Francis Marion University, 11 Florence SC, ${ }^{4}$ Center for Radiation Protection Knowledge, Oak Ridge National Laboratory, Oak Ridge TN, $12{ }^{5}$ J. Crayton Pruitt Family Department of Biomedical Engineering, University of Florida, Gainesville FL, 13 USA, ${ }^{6}$ Research and Development, Bayer AG, Wuppertal, Germany, ${ }^{7}$ Strategic Business Unit Oncology, 14 Bayer AG, Berlin, Germany, ${ }^{8}$ Translational Sciences Asia, Bayer, Beijing, China

15 Corresponding author: Shalini Subramanian (ssubramanian@rapiddosimetry.com)

16 Running Title: CE vs ICRP phantom dosimetry 
ABSTRACT

\section{Background}

3 In 2016, the International Commission on Radiological Protection and Measurements (ICRP), published

4 the results of Monte Carlo simulations performed using updated and anatomically realistic voxelized

5 phantoms. The resulting absorbed fractions are substantially more accurate than calculations based on the

6 Cristy-Eckerman (CE) stylized (or mathematical) phantoms. Despite this development, the ICRP absorbed

7 fractions have not been widely adopted for radiopharmaceutical dosimetry. To help make the transition, we

8 have established a correspondence between tissues defined in the CE phantom and those defined in the

9 ICRP phantoms. Using pre-clinical data from biodistribution studies performed, we have calculated

10 absorbed doses for Th-227 labeled HER2 targeted antibody. We compare the CE phantom-based

11 calculations as implemented in the OLINDA v1 software with those obtained using ICRP absorbed

12 fractions as implemented in 3D-RD-S, a newly developed software package that implements the MIRD S-

13 value methodology. We also compare ICRP values with a hybrid set of calculations in which alpha-particle

14 energy was assumed completely absorbed in activity containing tissues.

\section{Results}

16 We observed a non-negligible difference in the absorbed dose calculated using each of the methods for each

17 radiation type. This can be attributed to a combination of greater accuracy in absorbed fraction calculations

18 and differences in the time integrated activity coefficient values due to difference in representation of

19 anatomy by the phantoms. The total absorbed dose for Thorium-227 was dominated by alpha particles,

20 hence the differences in beta and photon absorbed doses were inconsequential in terms of total dose.

\section{Conclusion}

22 The results obtained by comparing these different implementations of the MIRD S value methodology

23 provide the data needed to help the field transition to the more anatomically accurate ICRP phantom-based

24 dosimetry.

25 Key words: ICRP phantom, radiopharmaceutical dosimetry, Cristy-Eckerman phantom 


\section{INTRODUCTION}

2 The Medical Internal Radiation Dose Committee published MIRD Pamphlet No. 1 in 1968. This Pamphlet,

3 along with Pamphlet Numbers 5 [1] and 11 [2] introduced the dosimetry formalism for biologically

4 distributed radionuclides [3]. The most recent update to this formalism [4], maintains the fundamental

5 innovation of the first series of pamphlets. The absorbed dose to a target region from a given source region

6 is the product of the total number of nuclear transformations that have occurred in the source region over a

7 specified time-period, multiplied by the radionuclide- and target-source region-specific radionuclide $\mathrm{S}$

8 value. The $\mathrm{S}$ value embodies the key innovation of the MIRD formalism over previous methods [5]. It

9 defines the absorbed dose to a target tissue per unit transformation of the radionuclide in a source tissue.

10 As such, it depends upon the emission properties of the radionuclide and the source-target tissue anatomy

11 (i.e., their shape, relative distance and their elemental composition as well as the composition of all tissues

12 in between). Consistent with the computational capabilities of the time, the source-target tissue anatomy

13 (or reference phantom) of the Cristy and Eckerman (CE) phantom set [6, 7] was used to calculate $\mathrm{S}$ values

14 that are still in widespread use today. The CE phantom series represents organs as simple geometrical

15 shapes or combinations thereof. Eighteen distinct tissues are represented, along with the general category,

16 "other tissues." The calculations were performed by Monte Carlo simulation of photon transport and energy

17 deposition. Due to its greater computational demands at the time, electron transport was not performed, and

18 the energy associated with all electron emissions was assumed either completely absorbed in the source

19 tissue or, in the case of walled organs, the dose present at the wall-content interface was taken to be one-

20 half of the self-dose to the organ contents. Alpha-particles were not initially considered in the CE phantom

21 calculations since radionuclides used for medical imaging did not emit alpha-particles. Absorbed fractions

22 for alpha-particle emitters were subsequently introduced into the CE phantom framework and implemented

23 into the software package OLINDA/EXM v1 [8].

24 In 2016, the International Commission on Radiological Protection and Measurements (ICRP), published

25 the results of Monte Carlo simulations performed using updated and much more realistic voxelized 
1 phantoms [9]. In these phantoms, source and target regions are defined by segmentation in Computed

2 Tomography (CT) data collected across patients and voxel-based scaling. Seventy-nine distinct source

3 regions along with 43 target regions were defined in these new phantoms. Of greater significance to more

4 accurately calculating tissue absorbed dose, both electron and alpha-particle transport (using stylized

5 models for selected tissue) were simulated along with the more accurate photon simulations. The greater

6 accuracy resulting from use of these new phantoms is essential for emerging Radiopharmaceutical Therapy

7 (RPT) applications of dosimetry.

8 Using data from a preclinical biodistribution study of a thorium-227 labeled HER2 targeted antibody, we

9 compare in this study calculations performed using S-value data from the CE phantom and those using S-

10 values from the more recent ICRP phantoms. We begin by establishing the anatomical correspondence

11 between CE vs ICRP source and target tissues to identify differences resulting from mass and geometry

12 updates vs those resulting from more accurate methods of assigning absorbed fractions by radiation type.

\section{CE vs ICRP Source and Target Region Geometries and their Correspondence}

14 In 2008, the ICRP established for the first time its own voxelized reference phantoms for the adult male 15 and adult female [18]. These phantoms were based upon CT imaging of height-weight matched patients, 16 and subsequently altered to specifically match reference values of organ mass given in ICRP Publication

17 89. The Publication 110 reference phantoms provide a detailed description of the human anatomy for a 18 total of 79 source regions and 43 target regions [10][18].

19 The updated ICRP phantom regions reflect the ICRP's focus on radiation protection in that a number of the

20 included more detailed anatomical regions support organ dosimetry associated with inhaled or ingested

21 radionuclides. Although some of these regions may also be relevant source or target regions for

22 radiopharmaceutical therapy in certain circumstances, a number of them are not. The respiratory tract and

23 alimentary tract models illustrate this difference in dosimetric purpose. The expanded versions of these two

24 anatomical systems constitute more than half of the source regions listed in ICRP revised publications. 


\section{$1 \quad$ ICRP Respiratory Tract Model}

2 To study the effects of inhaled radioactivity, the morphological model of respiratory tract is divided into

3 five tissue regions associated with deposited radioactive aerosols along the wall of the respiratory tract.

4 These include ET1 (Anterior Nasal Cavity), ET2 (Posterior Nasal Cavity), BB (Bronchial region), bb

5 (Bronchiolar region), and AI (Alveolar Interstitial) which collectively define the respiratory airways.

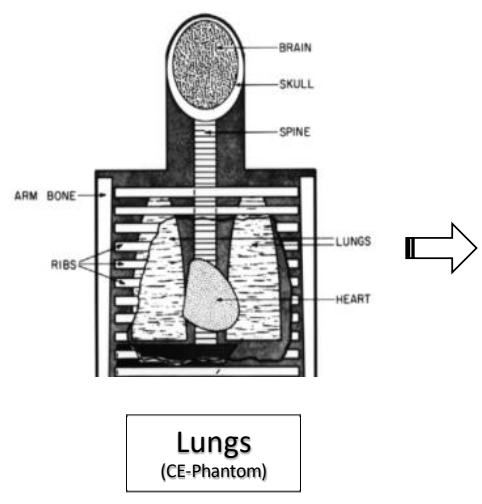

Figure 1. CE to ICRP transition for respiratory tract phantom geometry of source organs (figure adapted from

$$
\text { ICRP publication } 66 \text { and [6]) }
$$

9 The updated respiratory tract phantom geometry divides the respiratory tract into several individual source

10 tissue regions into which inhaled radionuclides may deposit. Figure 1 shows the transition from source

11 regions defined in the $\mathrm{CE}$ phantom to the morphological phantom developed by the ICRP. The regions of

12 interest for nuclear medicine can be narrowed down to a subset of the regions constituting each section

13 mentioned above. Figure 2 depicts the CE phantom lung regions and the corresponding regions in the ICRP

14 phantom that are relevant to nuclear medicine. As seen by comparing the information on the models in

15 Figure 1 and Figure 2, these are a subset of the comprehensive list of all source regions provided in the

16 ICRP phantom (Appendix, Table 2). 
1 There are three regions in the ICRP phantom that are coincident with "lungs" as described in the CE 2 phantom. These ICRP phantom regions are listed as: "lungs," "alveolar-interstitial (AI)," and "lung tissue".

Source Regions - Respiratory Tract

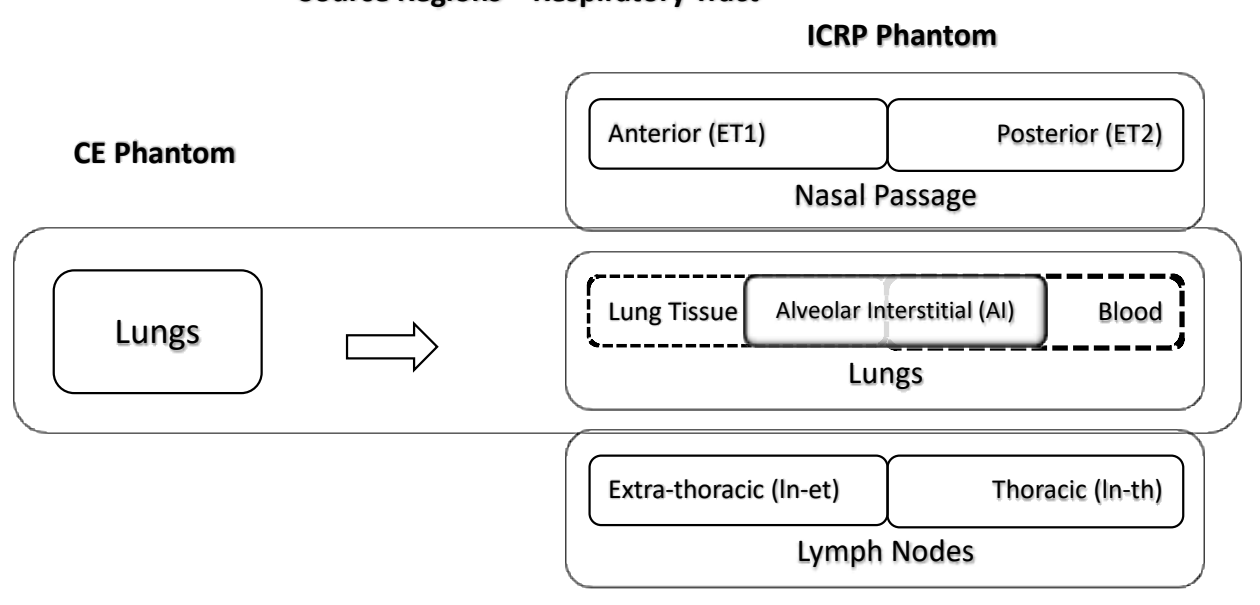

4 Figure 2. Simplified ICRP Respiratory tract phantom mapping CE source region for applications in diagnosis 5 and therapy

6 The region listed as "lung tissue" corresponds to all soft tissues within the lungs (e.g., lung parenchyma)

7 but exclusive of all blood within the lungs (pulmonary arteries, capillaries, and veins). In contrast, the

8 ICRP region listed as "lungs" includes both the lung tissue and its blood content. This distinction is relevant

9 only for biokinetic modeling, in terms of S values, as these two source regions are identical. Studies cited

10 in ICRP Publication 66 suggest that blood represents about $58 \%$ of the mass of the lungs. The "AI" region

11 is defined as the tissue region supporting the terminal bronchioles. It corresponds to the sub-region of the

12 lungs where oxygen and carbon dioxide exchange between air in the lungs and the blood gases take place.

13 This region is particularly relevant to dosimetry associated with inhaled radioactive particles or potentially

14 to radioactive gas released from the circulation and thus a potential critical target region for emissions

15 originating in adjacent source regions. Figure 3 represents the most appropriate target tissue mapping from

16 the CE Phantom to the ICRP phantom. The secretory and basal cells are the relevant targets for radiogenic

17 lung cancer, and thus they are used by the ICRP in their computation of "lung dose" for radioprotection.

18 For RPT, however, a lung target most representative of the risk of lung fibrosis (or other deterministic

19 effect) is more appropriate. The best ICRP target here would be AI. 
Target Regions - Respiratory Tract

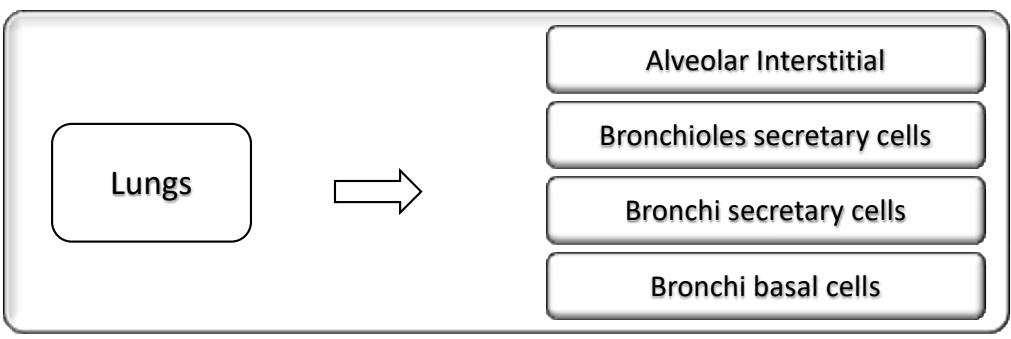

Figure 3: Target Tissue Mapping CE to ICRP

\section{$3 \quad$ Alimentary Tract}

4 The source regions in the alimentary tract are also differentiated to more explicitly identify tissues that

5 encounter ingested activity (or activity that was inhaled and transferred to the alimentary tract via

6 mucociliary clearance mechanisms). Numerous additional source regions have been defined as a result of

7 alimentary tract phantom development; several of these tissues are not easily sampled either directly or by

8 nuclear medicine imaging, but were included by the ICRP because they are part of their series of

9 radionuclide biokinetic models [11]. This includes tissues in contact with activity due to subsequent

10 transport from the GI tract to blood and organ secretions. Error! Reference source not found. shows the

11 evolution of the alimentary tract model from the eight source regions in the CE model to the current ICRP

12 model. In the $\mathrm{CE}$ phantom, the $\mathrm{S}$ values were calculated using Monte Carlo simulation for radionuclide

13 disintegrations occurring only within organ contents. For the small intestine, however, there is no geometric

14 separation between SI wall and SI content in the CE phantoms. By contrast, the ICRP Monte Carlo

15 simulations were performed for disintegrations occurring within both the GI tract walls (specifically their

16 mucosal layer) as well as the contents of the GI tract lumen. Furthermore, the regions are redefined in the

17 ICRP phantom so that the Large intestine (LI) is no longer divided into Upper Large Intestine (ULI) and

18 Lower Large Intestine (LLI). Instead, these regions are now redefined as Left Colon (LC), Right Colon

19 (RC) and Rectosigmoid Colon (RS) (Error! Reference source not found.); a division that better matches

20 experimental data on content transit times. 


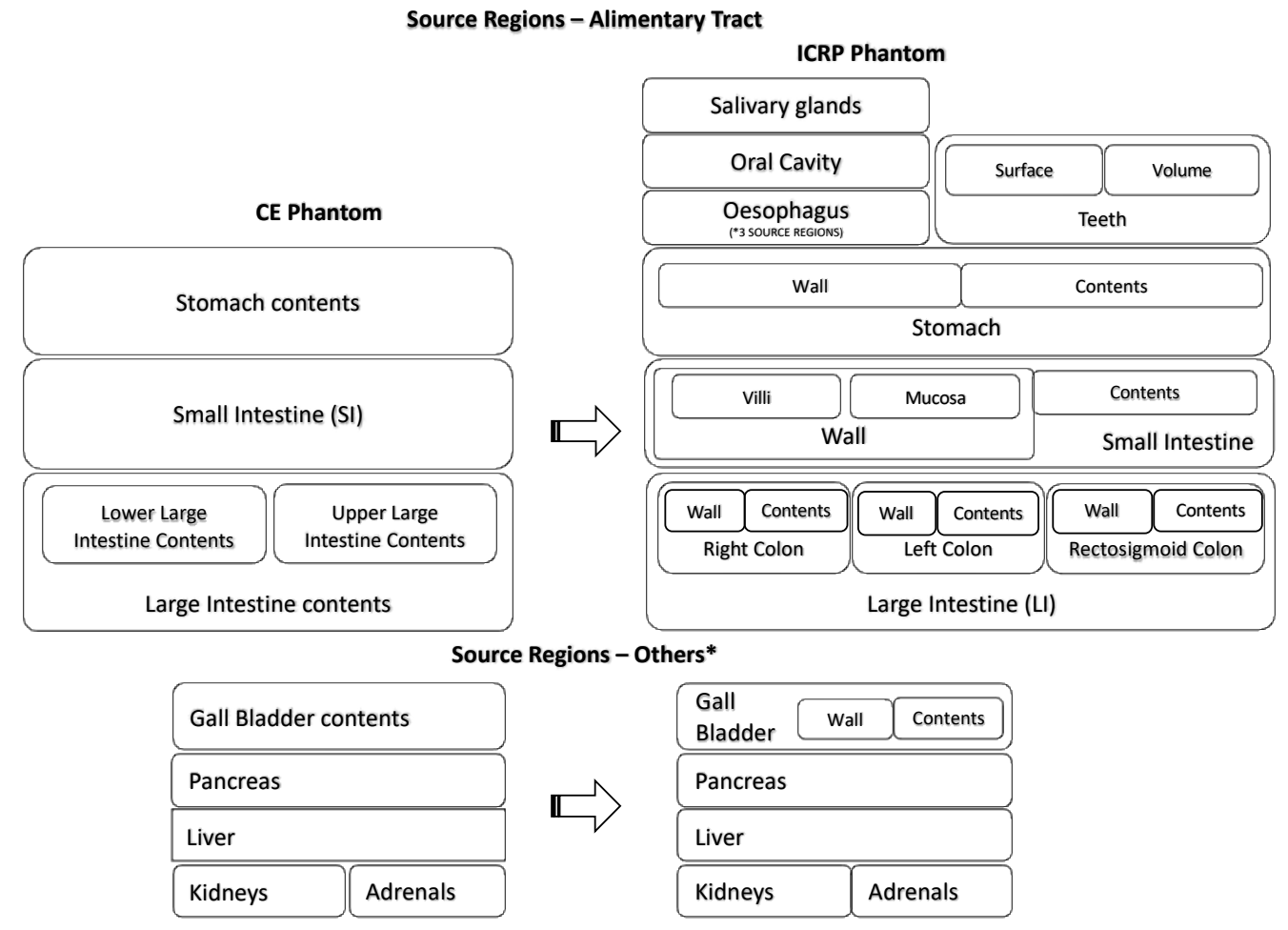

2 Figure 4: CE to ICRP transition in source regions for the alimentary tract. Regions that have not been

3 redefined are included on both the CE and ICRP sides of the figure in separate boxes. *Organs which

4 indirectly contribute to the functioning of the alimentary tract

5 The ICRP's alimentary tract model of Publication 100 [12], and which is implemented in the Publication

6110 adult phantoms, has additional source regions including the oesophagus, teeth, oral cavity, and salivary

7 glands. A portion of the activity in the oral cavity may also be apportioned to oral mucosa. The "salivary

8 glands" source region includes six regions - the left and right parotid, submandibular, and sublingual

9 glands.

10 The oesophageal wall, oral cavity mucosal lining, teeth surface, and salivary glands are relevant source or

11 target tissues for absorbed dose calculations in nuclear medicine therapy and diagnosis.

12 The colon (or large intestines in the CE nomenclature) regions that are defined in the ICRP phantom differ

13 from those in the CE phantom. To transition from the CE to the ICRP phantom, the total activity (ULI +

14 LLI) obtained from the CE phantom is apportioned to the three coincident regions based on their relative

15 masses in the ICRP model. 
1 Table 1 lists the mass and mapping factor required for an equivalent mapping. Assuming uniform

2 distribution of activity throughout the colon, the mapping factor times the total activity in the large intestines

3 gives the activity in the corresponding ICRP source regions.

4 Table 1: Mapping factor to transition from CE to ICRP model

\begin{tabular}{|l|l|l|l|l|}
\hline CE Source Regions & ICRP Source region & Acronym & Mass (g) & Mapping factor \\
\hline \multirow{2}{*}{$\begin{array}{l}\text { ULI (contents)+ } \\
\text { LLI (contents) }\end{array}$} & Right colon (contents) & RC-cont & 150 & 0.5 \\
\cline { 2 - 5 } & Left colon (contents) & LC-cont & 75 & 0.25 \\
\cline { 2 - 5 } & Rectosigmoid (contents) & RS-cont & 75 & 0.25 \\
\hline \multirow{2}{*}{$\begin{array}{l}\text { ULI (wall)+ (wall) } \\
\text { Right colon (wall) }\end{array}$} & RC-wall & 150 & 0.41 \\
\cline { 2 - 5 } & Left colon (wall) & LC-wall & 150 & 0.41 \\
\cline { 2 - 5 } & Rectosigmoid (wall) & RS-wall & 70 & 0.18 \\
\hline
\end{tabular}

5 The ICRP phantom alimentary tract includes target regions deemed important in their impact on overall

6 tissue response to radiation. These include the oral mucosa, and the stem cell layers within the mucosal

7 layers of the stomach, small intestine and large intestine walls. Figure 4 illustrates the corresponding target

8 regions for the CE and ICRP phantoms.

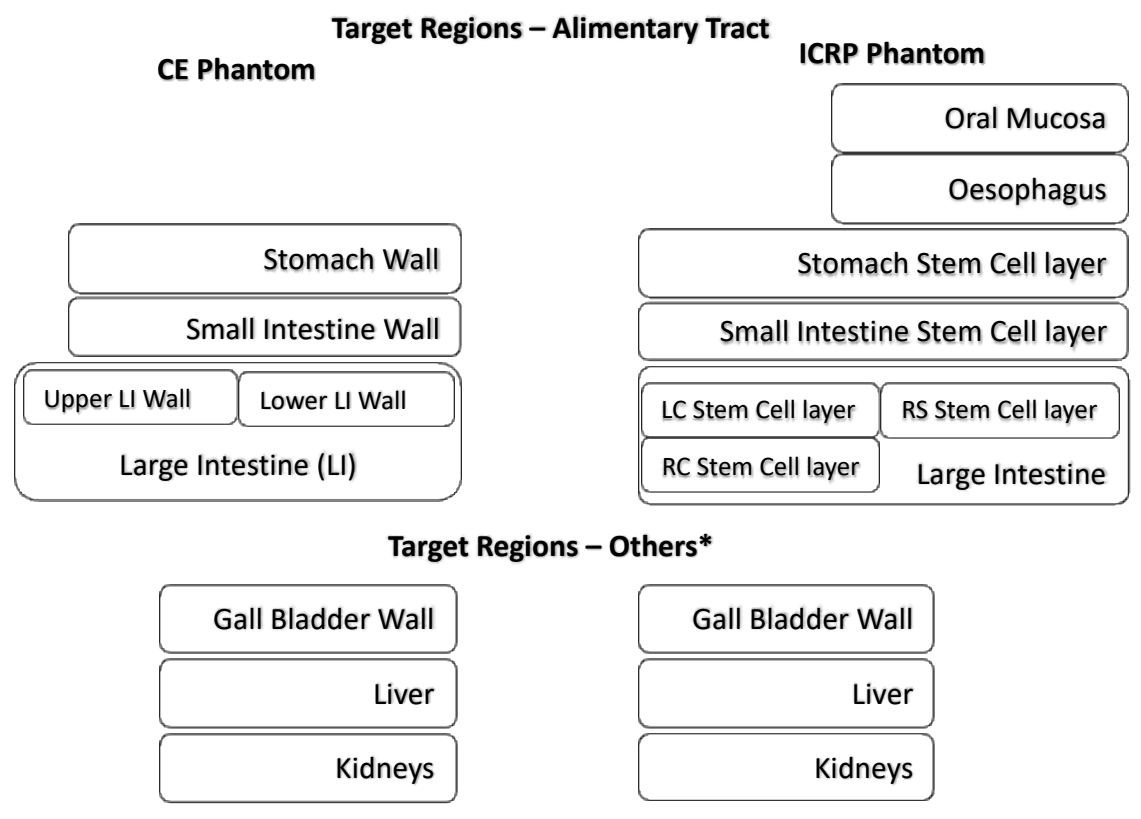

10 Figure 4: CEP to ICRP correspondence (target regions) for the alimentary tract. * Organs which indirectly contribute to the functioning of the alimentary tract 


\section{$1 \quad$ Skeletal tissues}

2 The active marrow, inactive marrow, trabecular and cortical bone are included as source regions in the

3 ICRP phantom's skeletal system representation. The active marrow is the only marrow source region

4 considered in the original CE phantom. Trabecular bone marrow and cortical bone marrow regions were

5 subsequently added into the CE phantom formulation.

6 The definition of bone endosteum has evolved over time. In the ICRP 30 model, bone endosteum was

7 defined as a single cell layer (10 microns in thickness) along all surfaces of bone trabeculae in trabecular

8 bone, and along the surfaces of the Haversian canals of cortical bone.

9 With the development of the ICRP 110 adult phantoms, the ICRP changed this target tissue (for radiogenic

10 bone cancer risk) to include a 50-micron region of bone marrow along the surfaces of the bone trabeculae,

11 and a 50-micron layer of marrow along the inner bone shafts of the long bones. Cortical bone is no longer

12 considered to house "endosteum" and thus is only a radiation source region and no longer a component of

13 the endosteum target region.

14 To summarize, the endosteum layer in the ICRP phantom and the osteogenic layer in the CE phantom are

15 the corresponding target regions for the skeletal system. The active marrow is another target region common

16 to both the CE and ICRP phantoms. Both phantoms have endosteum as a target - but this target is

17 anatomically/ histological different in the two phantoms (Figure 5). 
Source Regions - Skeletal System

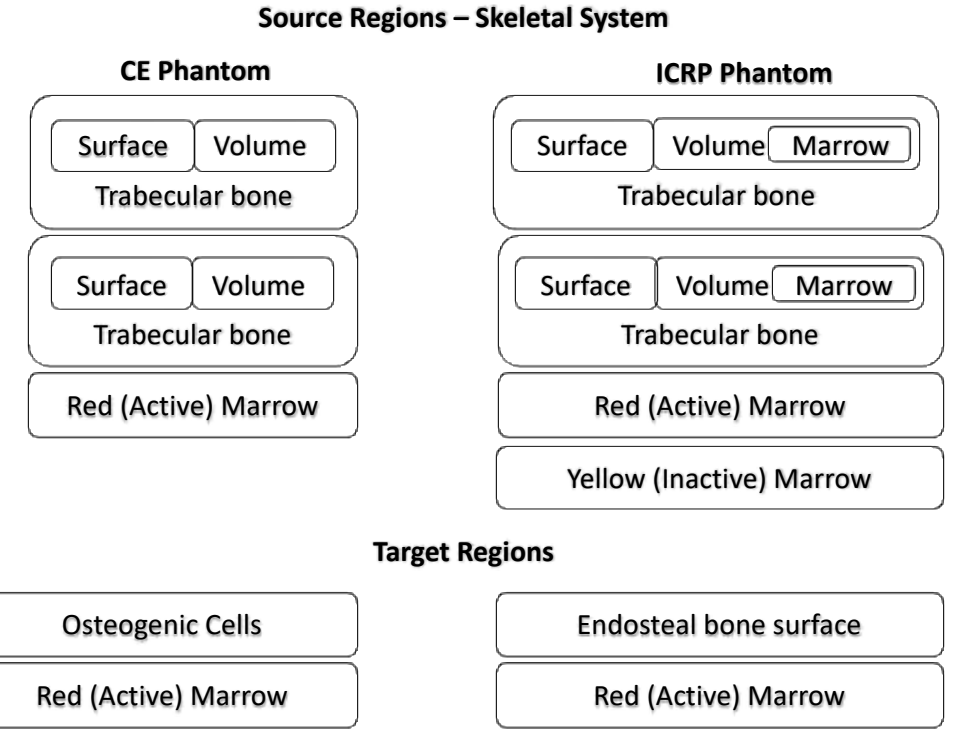

Figure 5: CE Phantom to ICRP phantom mapping in Skeletal system

3 The spleen, thymus, thyroid, ovaries, testes, uterus, brain, breast and heart are common as source regions

4 in both the ICRP and CE phantoms. In the CE phantom, the heart was divided into its contents and wall.

5 The ICRP phantom considers only the heart wall since total body blood is included as a distinct source

6 region. The lens of the eye, pituitary gland, tonsils, prostate, salivary glands (including the parotid,

7 submandibular and sublingual), teeth, oral cavity, adipose tissue and the ureters are new and additional

8 source regions defined within the ICRP adult phantom.

9 Similarly, there are a few other common target regions included in both models; these are listed in the

10 Appendix. There exist additional target regions corresponding to the additional source tissue in the ICRP

11 adult phantom resulting in a total of 43 target regions.

\section{Other source and target regions}

13 The CE phantom has a "residual soft tissue (RST)" region corresponding to interior regions of the phantoms

14 that are not already taken by other organs within the body. This RST region is used as a surrogate for

15 "muscle" as a source region and as a target region. In the ICRP phantoms, however explicit geometric

16 models for both "muscle" and "adipose" tissue are defined; there are no undefined regions in the ICRP 
1 phantoms, as there is in the CE phantoms. RST in the CE phantom would correspond to both muscle and

2 adipose tissue in the ICRP phantoms.

3 Target mass differences will impact the absorbed dose comparison. Table 2 summarizes target region

4 masses for the two different phantoms. The GI tract targets in the CE phantom were entire organ walls,

5 while in the ICRP phantoms they are stem cell layers embedded at depth within only the outer mucosal

6 layer of the GI tract walls.

7 Table 2: CE phantom to ICRP phantom mapping for target tissues

\begin{tabular}{|l|l|l|l|}
\hline CE Target Region & Mass (g) & ICRP Target Region & Mass (g) \\
\hline Lower LI Wall & $1.67 \mathrm{E}+02$ & Right Colon Stem Cell Layer & $1.35 \mathrm{E}+00$ \\
\hline Upper LI Wall & $2.20 \mathrm{E}+02$ & Left Colon Stem cell layer & $1.26 \mathrm{E}+00$ \\
\hline & & Rectosigmoid stem cell layer & $7.59 \mathrm{E}-01$ \\
\hline Stomach Wall & $1.58 \mathrm{E}+02$ & Stomach Stem cell layer & $6.16 \mathrm{E}-01$ \\
\hline $\begin{array}{l}\text { Small intestine } \\
\text { Osteogenic cells }\end{array}$ & $6.77 \mathrm{E}+02$ & Small intestine stem cell layer & $3.71 \mathrm{E}+00$ \\
\hline
\end{tabular}

\section{Blood as source region}

9 To facilitate biokinetic modeling wherein a central blood pool is a distinct physiologic compartment, the

10 ICRP phantom considers blood as a distinct source region. Accordingly, source regions correspond to and

11 are assigned the mass of tissue parenchyma. Activity in blood also contributes to the total organ activity,

12 and thus the organ self-doses and cross-doses. Source region activity values estimated from nuclear

13 medicine imaging will include activity in the whole organ (blood + parenchyma). Without special care,

14 using a measured blood value directly would lead to double counting of the blood in such regions since

15 source region activity measured from the image includes both the radiopharmaceutical activity in the organ

16 parenchyma as well as the radiopharmaceutical activity within the blood pool of that same organ. This can

17 be avoided by subtracting the fraction of total body blood activity that is localized within the blood pool of

18 the organ of interest (based upon reference blood distribution models [20]). The CE phantom does not

19 include blood as a source organ except for the heart-contents region. 
METHODS

2 Absorbed dose calculations were all performed using the standard MIRD methodology as most recently

3 described in MIRD Pamphlet 21 [4]. Within this framework, three different absorbed dose calculations are

4 compared:

5 1. CE phantom S-values (CEP): Using the CE phantom S-values and their modifications or additions as 6 implemented in OLINDA v1.

7 2. Hybrid method: CEP S values for electron and photon emissions (as obtained from an OLINDA v1

8 calculation) but assuming complete energy absorption for alphas (except for marrow).

9 3. ICRP phantom S values (ICRP): All calculations were performed using S values calculated from recently 10 released ICRP phantom specific absorbed fractions.

\section{Radionuclide decay scheme}

12 The particle yields and energies used for the absorbed dose calculations were obtained from ICRP 13 Publication 107 [12]. Thorium-227 ( $\mathrm{T}_{1 / 2}=18.72$ days) decays by $100 \%, 5.9 \mathrm{MeV}$ alpha particle emission

14 to Radium-223. An overview of the thorium-227 decay scheme is depicted in Figure 6. Alpha energies and 15 abundances from thorium-227 and daughters are summarized in Table 3.

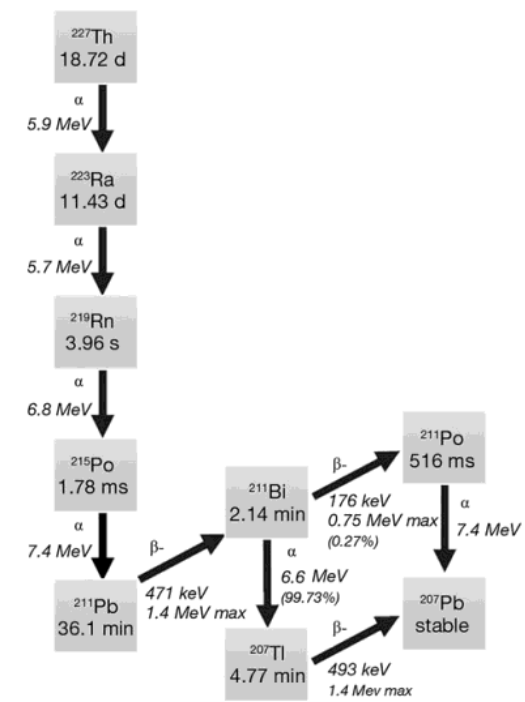


Table 3: Summary of thorium-227 and daughter alpha and electron emission energies

\begin{tabular}{|l|c|c|c|c|c|}
\hline \multicolumn{2}{|c}{} & \multicolumn{2}{c}{} & \multicolumn{2}{c|}{ Weighted by yield } \\
\hline Radionuclide & Yield & Alpha & Electron & Alpha & Electron \\
\hline thorium-227 & 1.000 & $9.43 \mathrm{E}-13$ & $1.21 \mathrm{E}-14$ & $9.43 \mathrm{E}-13$ & $1.21 \mathrm{E}-14$ \\
\hline radium-223 & 1.000 & $9.08 \mathrm{E}-13$ & $1.22 \mathrm{E}-14$ & $9.08 \mathrm{E}-13$ & $1.22 \mathrm{E}-14$ \\
\hline radon-219 & 1.000 & $1.08 \mathrm{E}-12$ & $1.09 \mathrm{E}-15$ & $1.08 \mathrm{E}-12$ & $1.09 \mathrm{E}-15$ \\
\hline polonium-215 & 1.000 & $1.18 \mathrm{E}-12$ & $2.34 \mathrm{E}-20$ & $1.18 \mathrm{E}-12$ & $2.34 \mathrm{E}-20$ \\
\hline lead-211 & 1.000 & $0.00 \mathrm{E}+00$ & $7.24 \mathrm{E}-14$ & $0.00 \mathrm{E}+00$ & $7.24 \mathrm{E}-14$ \\
\hline bismuth-211 & 1.000 & $1.05 \mathrm{E}-12$ & $1.60 \mathrm{E}-15$ & $1.05 \mathrm{E}-12$ & $1.60 \mathrm{E}-15$ \\
\hline thallium-207 & 0.997 & $0.00 \mathrm{E}+00$ & $7.93 \mathrm{E}-14$ & $0.00 \mathrm{E}+00$ & $7.91 \mathrm{E}-14$ \\
\hline polonium-211 & 0.00276 & $1.19 \mathrm{E}-12$ & $1.26 \mathrm{E}-19$ & $3.29 \mathrm{E}-15$ & $3.48 \mathrm{E}-22$ \\
\hline radium-223 \& daughters & & & & $4.23 \mathrm{E}-12$ & $1.66 \mathrm{E}-13$ \\
\hline
\end{tabular}

\section{Input to Calculations}

3 Input data for these calculations were obtained from pre-clinical biodistribution measurements of a thorium-

4227 labeled HER2 targeted monoclonal antibody (mAb), injected intravenously.

\section{Time Integrated Activity Coefficient (TIAC)}

6 The time-integrated activity coefficient (TIAC $=$ residence time $)$, i.e., the integral over time of the activity

7 in the organ divided by the injected activity, expressed as fraction of injected activity [hours per g (FIA-

$8 \mathrm{~h} / \mathrm{g})]$ for each pre-clinical organ are shown in Table 4.

9 Table 4: Pre-clinical tissue TIAC concentration

\begin{tabular}{|l|r|r|}
\hline Tissue & $\begin{array}{l}\text { Thorium-227 } \\
\text { [TIAC] FIA- } \\
\text { h/g }\end{array}$ & $\begin{array}{l}\text { Radium-223 } \\
\text { [TIAC] FIA-h/g }\end{array}$ \\
\hline Adrenal Left & $1.71 \mathrm{E}-01$ & $0.00 \mathrm{E}+00$ \\
\hline Adrenal right & $1.54 \mathrm{E}-01$ & $0.00 \mathrm{E}+00$ \\
\hline Bile & $2.05 \mathrm{E}-02$ & $6.90 \mathrm{E}-03$ \\
\hline Bone marrow (from femur) & $9.54 \mathrm{E}-03$ & $0.00 \mathrm{E}+00$ \\
\hline Brain & $2.96 \mathrm{E}-03$ & $0.00 \mathrm{E}+00$ \\
\hline
\end{tabular}




\begin{tabular}{|l|r|r|}
\hline Core bone sample of the distal femur & $4.27 \mathrm{E}-02$ & $6.02 \mathrm{E}-02$ \\
\hline Gall bladder & $2.59 \mathrm{E}-01$ & $1.36 \mathrm{E}-02$ \\
\hline Heart and pericardium & $6.44 \mathrm{E}-02$ & $6.46 \mathrm{E}-03$ \\
\hline Kidney left & $4.66 \mathrm{E}-01$ & $4.60 \mathrm{E}-02$ \\
\hline Kidney right & $4.69 \mathrm{E}-01$ & $4.92 \mathrm{E}-02$ \\
\hline L2 vertebral body & $3.97 \mathrm{E}-01$ & $3.24 \mathrm{E}-01$ \\
\hline Large intestine & $6.73 \mathrm{E}-02$ & $1.10 \mathrm{E}-01$ \\
\hline Liver & $2.21 \mathrm{E}+00$ & $2.51 \mathrm{E}-01$ \\
\hline Lung left & $9.34 \mathrm{E}-02$ & $2.19 \mathrm{E}-03$ \\
\hline Lung right & $8.43 \mathrm{E}-02$ & $9.13 \mathrm{E}-03$ \\
\hline Mesenteric lymph node & $7.42 \mathrm{E}-02$ & $0.00 \mathrm{E}+00$ \\
\hline Muscle & $3.44 \mathrm{E}-03$ & $0.00 \mathrm{E}+00$ \\
\hline Pancreas & $5.74 \mathrm{E}-02$ & $2.50 \mathrm{E}-03$ \\
\hline Prostate & $1.26 \mathrm{E}-01$ & $0.00 \mathrm{E}+00$ \\
\hline Spina Capula & $4.99 \mathrm{E}-02$ & $1.00 \mathrm{E}-01$ \\
\hline Small intestine & $1.33 \mathrm{E}-01$ & $9.04 \mathrm{E}-02$ \\
\hline Spleen & $3.30 \mathrm{E}-01$ & $4.12 \mathrm{E}-02$ \\
\hline Testes left & $3.87 \mathrm{E}-02$ & $6.84 \mathrm{E}-04$ \\
\hline Testes right & $4.80 \mathrm{E}-02$ & $2.74 \mathrm{E}-03$ \\
\hline Thyroid right & $1.43 \mathrm{E}-02$ & $0.00 \mathrm{E}+00$ \\
\hline
\end{tabular}

\section{Pre-clinical to human TIAC conversion}

2 The TIAC per g, for each pre-clinical organ was converted to human equivalent FIA-h per organ using the

3 following equation:

$4 \quad\left[\frac{\mathrm{TIAC}}{\text { organ }}\right]_{\mathrm{H}}=\left[\frac{\mathrm{TIAC}}{\mathrm{g}}\right]_{\mathrm{P}} \cdot \mathrm{TBM}_{\mathrm{P}} \cdot \frac{\mathrm{OM}_{\mathrm{H}}}{\mathrm{TBM}_{\mathrm{H}}}$

5 with:

$6 \quad \mathrm{TBM}_{P}$ Total body mass of the pre-clinical model

$7 \quad \mathrm{OM}_{\mathrm{H}} \quad$ Human organ mass (ICRP89 [10] compilation of masses)

$8 \mathrm{TBM}_{\mathrm{H}}$ Human total body mass (set to $73.7 \mathrm{~kg}$ ).

9 Adult male human organ masses from ICRP 89 and CE-phantom were used in the calculations. 


\section{Bone and GI TIAC apportionment}

2 The TIAC of the pre-clinical "core bone sample of the distal femur" was assigned to human cortical bone

3 and "L2 vertebral body" was assigned to trabeculae bone using equation 1 . This assignment was used to

4 obtain electron and photon dose contributions to the osteogenic cell target in the CE phantom region. The

5 L2 vertebral body measurement was also used in the hybrid calculations to apportion the TIAC to

6 osteogenic cells, which was taken to be equivalent to the trabecular bone endosteum layer as defined in

7 [13]. In the calculations using ICRP data, trabecular bone surface (which has zero mass in the ICRP model)

8 serves as a source region. Thus, we assigned the TIAC to this region using the ICRP trabecular bone marrow

9 mass in the conversion from pre-clinical L2 TIAC to human TIAC.

10 The large intestine TIAC was apportioned to human upper and lower large intestine for the CEP and Hybrid

11 calculation. For the ICRP calculation, the adult reference male phantom was used and the large intestine

12 TIAC was apportioned to the right, left and rectosigmoid colon regions based on the mapping factors

13 described above.

\section{Absorbed Dose Estimation}

\section{CE phantom S values}

16 Equation 2 describes the general approach.

$17 \quad \mathrm{D}\left(\mathrm{r}_{\mathrm{T}}\right)=\sum_{\mathrm{r}_{\mathrm{S}}} \widetilde{\mathrm{A}}\left(\mathrm{r}_{\mathrm{S}}\right) \cdot \mathrm{S}\left(\mathrm{r}_{\mathrm{T}} \leftarrow \mathrm{r}_{\mathrm{S}}\right)$

18 with:

$19 \mathrm{r}_{\mathrm{T}}, \mathrm{r}_{\mathrm{S}} \quad$ target, source region (or tissue), respectively.

$20 \quad \mathrm{D}\left(\mathrm{r}_{\mathrm{T}}\right) \quad$ total absorbed dose to $\mathrm{r}_{\mathrm{T}}$.

$21 \quad \widetilde{A}\left(r_{S}\right) \quad$ time-integrated activity (TIA), i.e., total number of nuclear transitions in $r_{S}$.

$22 \quad \mathrm{~S}\left(\mathrm{r}_{\mathrm{T}} \leftarrow \mathrm{r}_{\mathrm{S}}\right) \quad$ S-value absorbed dose to $\mathrm{r}_{\mathrm{T}}$ per TIA in source region, $\mathrm{r}_{\mathrm{S}}$. 
1 The general absorbed dose equation described in (Eq. 2) was applied using OLINDA to obtain the

2 individual dose contributions from alpha-particles, electrons and photons.

\section{Hybrid method}

4 OLINDA-based estimates of the alpha-particle dose to each target tissue were replaced by separate

5 calculations that used the summed alpha-particle energy for thorium-227 and radium-223 as listed in Table

6 3. The equations describing this approach are given below.

$8 \quad \mathrm{D}_{\alpha}\left(\mathrm{r}_{\mathrm{T}}\right)=\widetilde{\mathrm{A}}\left(\mathrm{r}_{\mathrm{S}}\right) \cdot \frac{\sum_{\mathrm{i}} \Delta_{\mathrm{i}}^{\alpha} \phi\left(\mathrm{r}_{\mathrm{T}} r_{\mathrm{S}} ; \mathrm{E}_{\mathrm{i}}^{\alpha}\right)}{\mathrm{M}\left(\mathrm{r}_{\mathrm{T}}\right)}$, and

$9 \quad \mathrm{D}\left(\mathrm{r}_{\mathrm{T}}\right)=\mathrm{D}_{\mathrm{e}, \mathrm{ph}}\left(\mathrm{r}_{\mathrm{T}}\right)+\mathrm{D}_{\alpha}\left(\mathrm{r}_{\mathrm{T}}\right)$,

10 where,

$11 \mathrm{D}_{\mathrm{e}, \mathrm{ph}}\left(\mathrm{r}_{\mathrm{T}}\right)$ is the electron (e) and photon (ph) dose contribution to target region, $\mathrm{r}_{\mathrm{T}}$,

$12 \mathrm{D}_{\alpha}\left(\mathrm{r}_{\mathrm{T}}\right)$ is the alpha-particle (a) dose contribution to $\mathrm{r}_{\mathrm{T}}$,

$13 \quad \mathrm{D}\left(\mathrm{r}_{\mathrm{T}}\right)$ is the total absorbed dose to $\mathrm{r}_{\mathrm{T}}$,

$14 \mathrm{~S}^{\mathrm{e}, \mathrm{ph}}\left(\mathrm{r}_{\mathrm{T}} \leftarrow \mathrm{r}_{\mathrm{S}}\right)$ is the $\mathrm{S}$ value, i.e., the absorbed dose to $\mathrm{r}_{\mathrm{T}}$ from e and ph emissions per nuclear 15 transition in source region, $\mathrm{r}_{\mathrm{S}}$,

$16 \quad \mathrm{M}\left(\mathrm{r}_{\mathrm{T}}\right)$ is the mass of $\mathrm{r}_{\mathrm{T}}$,

$17 \Delta \Delta_{\mathrm{i}}^{\alpha}$ is the mean energy emitted per nuclear transition of the $\mathrm{i}^{\text {th }}$ alpha particle $(\alpha)$ emission, and

$\phi\left(\mathrm{r}_{\mathrm{T}} \leftarrow \mathrm{r}_{\mathrm{S}} ; \mathrm{E}_{\mathrm{i}}^{\alpha}\right)$ is the fraction of energy emitted per nuclear transition in the source region, $\mathrm{r}_{\mathrm{S}}$, that is 20 absorbed in the target region, $r_{T}$, by the $i^{\text {th }}$ alpha-particle emission emitted with 21 energy E. 
1 Since the calculations are performed at the level of whole organ dimensions, the following holds:

$2 \phi\left(\mathrm{r}_{\mathrm{T}} \leftarrow \mathrm{r}_{\mathrm{S}} ; \mathrm{E}_{\mathrm{i}}^{\alpha}\right)=\left\{\begin{array}{ll}0 & \mathrm{r}_{\mathrm{T}} \neq \mathrm{r}_{\mathrm{S}} \\ 1 & \mathrm{r}_{\mathrm{T}}=\mathrm{r}_{\mathrm{S}}\end{array}\right.$.

3 Accordingly, equation 4 reduces to:

$4 \quad \mathrm{D}_{\alpha}\left(\mathrm{r}_{\mathrm{T}}\right)=\frac{\widetilde{\mathrm{A}}\left(\mathrm{r}_{\mathrm{T}}\right) \cdot \Delta^{\alpha}}{\mathrm{M}\left(\mathrm{r}_{\mathrm{T}}\right)}$

5 where,

$6 \Delta^{\alpha}$ is the total $\alpha$-particle energy emitted per nuclear transition of the radionuclide, $(\mathrm{Gy}-\mathrm{kg}) /(\mathrm{Bq}-\mathrm{s})$.

8 Equation 7 was derived assuming the emitted $\alpha$-particle energy is completely absorbed in $\mathrm{r}_{\mathrm{T}}$.

9 There is ample evidence that the first assumption (Eq. 6) fails for some tissues. In particular, the distribution 10 of the mAb through the kidneys is known to be non-uniform. The second assumption (Eq. 7) is met if the

11 target region is substantially larger than the 60 to $100 \mu \mathrm{m}$ range of the $\alpha$-particles. Since radium-223 has a 12 biodistribution different from thorium-227 labeled anti-HER2-antibody, Equation 7 was implemented 13 separately for these two $\alpha$-emitters.

14 Marrow, trabecular bone and endosteum S values

15 Equation 7 above was applied to all tissues except for skeletal tissues. The skeletal-averaged absorbed 16 fractions (f) for the 40-year old reference male, described in ICRP 70 [14] as tabulated by Watchman et al.

17 [13], were used to calculate $\mathrm{S}$ values for the trabecular active marrow (TAM) and the trabecular bone 18 endosteum (TBE) from alpha-particle emissions in these two volumes as follows:

$19 \quad \mathrm{~S}(\mathrm{TAM} \leftarrow \mathrm{TAM})=\frac{\sum_{\mathrm{i}} \mathrm{E}_{\mathrm{i}}^{\alpha} \mathrm{Y}_{\mathrm{i}}^{\alpha} \phi\left(\mathrm{TAM} \leftarrow \mathrm{TAM} ; \mathrm{E}_{\mathrm{i}}^{\alpha}\right)}{\mathrm{M}(\mathrm{TAM})}$,

$20 \quad \mathrm{~S}(\mathrm{TAM} \leftarrow \mathrm{TBE})=\frac{\sum_{\mathrm{i}} \mathrm{E}_{\mathrm{i}}^{\alpha} \mathrm{Y}_{\mathrm{i}}^{\alpha} \phi\left(\mathrm{TAM} \leftarrow \mathrm{TBE} ; \mathrm{E}_{\mathrm{i}}^{\alpha}\right)}{\mathrm{M}(\mathrm{TAM})}$,

$21 \quad \mathrm{~S}(\mathrm{TBE} \leftarrow \mathrm{TAM})=\frac{\sum_{\mathrm{i}} \mathrm{E}_{\mathrm{i}}^{\alpha} \mathrm{Y}_{\mathrm{i}}^{\alpha} \phi\left(\mathrm{TBE} \leftarrow \mathrm{TAM} ; \mathrm{E}_{\mathrm{i}}^{\alpha}\right)}{\mathrm{M}(\mathrm{TBE})}$, 
$1 \quad \mathrm{~S}(\mathrm{TBE} \leftarrow \mathrm{TBE})=\frac{\sum_{\mathrm{i}} \mathrm{E}_{\mathrm{i}}^{\alpha} \mathrm{Y}_{\mathrm{i}}^{\alpha} \phi\left(\mathrm{TBE} \leftarrow \mathrm{TBE} ; \mathrm{E}_{\mathrm{i}}^{\alpha}\right)}{\mathrm{M}(\mathrm{TBE})}$, and

2 where,

$3 \mathrm{M}(\mathrm{TAM})$ and $\mathrm{M}(\mathrm{TBE})$ are the mases of TAM and TBE, respectively, and

$4 \quad \mathrm{E}_{\mathrm{i}}^{\alpha}$ and $\mathrm{Y}_{\mathrm{i}}^{\alpha}$ are the energy and yield, respectively, of alpha-particle i emitted by thorium-227 or radium-

5223 and its daughters.

6 The TAM and TBE masses (Table 5) were obtained from data in ICRP 89, ICRP 70 and Watchman, et al.

$7[10,13,14]$. The mass of the TBE was obtained as the product of the trabecular bone surface area, the 10

$8 \mu \mathrm{m}$-thickness of the endosteal layer, and the density of the endosteal layer. The mass used for the TAM

9 was consistent with the cellularity of the reference 40-year-old male.

10 Table 5: Masses (M) used in the skeletal dosimetry calculations

\begin{tabular}{|l|l|l|}
\hline Target mass & Value & Reference \\
\hline $\mathrm{M}\left(\mathrm{TAM}^{1}\right)$ & $1.09 \mathrm{~kg}$ & Table 5 from [13] \\
\hline $\mathrm{M}\left(\mathrm{TBE}^{1}\right)$ & $1.05 \times 10^{5} \mathrm{~cm}^{2} \times 1.0 \times 10^{-3} \mathrm{~cm} \times 1.03 \times 10^{-3} \mathrm{~kg} / \mathrm{cm}^{3}$ & Error! Reference \\
& $=0.108 \mathrm{~kg}$ & source not found. \\
& & from [13], \\
& & ICRP 89, Pg. 174 [10] \\
\hline
\end{tabular}

$11{ }^{1}$ TAM - Trabecular Active Marrow, TBE - Trabecular Bone Endosteum

12 The energy and associated yield of each alpha-particle emission in the decay of thorium-227 and radium-

13223 were obtained from the MIRD Radionuclide data and decay schemes [15]. Absorbed fractions

14 corresponding to $\mathrm{E}_{\mathrm{i}}^{\alpha}$ were obtained from Table 7 of Watchman, et al. by linear interpolation. All alpha-

15 particles in the decay scheme were considered in the calculation; energy associated with daughter recoil

16 was excluded since this does not contribute to biologic effects [16]. Table 6 provides the $\mathrm{S}$ values obtained

17 using equations 8 to 11 . 
Table 6: S values used in the skeletal dosimetry calculations

\begin{tabular}{|l|c|c|c|c|}
\hline \multicolumn{1}{|c|}{ Radionuclide } & \multicolumn{3}{|c|}{ Skeletal dosimetry S values* $(\mathbf{G y} / \mathbf{B q}-\mathbf{s})$} \\
\hline & $\mathrm{TAM} \mathrm{TBE}^{1}$ & $\mathrm{TBE} \leftarrow \mathrm{TBE}$ & $\mathrm{TAM} \leftarrow \mathrm{TAM}$ & $\mathrm{TBE} \leftarrow \mathrm{TAM}$ \\
\hline thorium-227 & $1.79 \mathrm{E}-13$ & $1.85 \mathrm{E}-12$ & $6.28 \mathrm{E}-13$ & $1.45 \mathrm{E}-13$ \\
\hline radium-223 and daughters & $8.35 \mathrm{E}-13$ & $7.24 \mathrm{E}-12$ & $2.70 \mathrm{E}-12$ & $6.63 \mathrm{E}-13$ \\
\hline
\end{tabular}

*Electron and photon emissions not included.

$3 \quad{ }^{1}$ TAM - Trabecular Active Marrow, TBE - Trabecular Bone Endosteum

4 Equating red marrow to TAM and assuming that osteogenic cells lie in the endosteal layer of trabecular

5 bone, the absorbed dose (D) to red marrow and to the osteogenic cells due to alpha-particle emissions was

6 calculated using:

$7 \quad \mathrm{D}($ red marrow $)=\widetilde{\mathrm{A}}(\mathrm{TAM}) \mathrm{S}(\mathrm{TAM} \leftarrow \mathrm{TAM})+\widetilde{\mathrm{A}}(\mathrm{TBE}) \mathrm{S}(\mathrm{TAM} \leftarrow \mathrm{TBE})$, and

$\mathrm{D}($ osteogenic cells $)=\widetilde{\mathrm{A}}(\mathrm{TAM}) \mathrm{S}(\mathrm{TBE} \leftarrow \mathrm{TAM})+\widetilde{\mathrm{A}}(\mathrm{TBE}) \mathrm{S}(\mathrm{TBE} \leftarrow \mathrm{TBE})$.

9 These values were added to the electron and photon absorbed doses obtained from OLINDA.

\section{ICRP Phantom based dose calculation}

11 This method implemented the MIRD Committee S value methodology [2, 4] using S values derived from

12 absorbed fractions from ICRP-133 and radionuclide decay data in ICRP-107 [12]. The absorbed fractions

13 were interpolated using the piecewise cubic Hermite interpolating polynomial (PCHIP) method [17]. The

14 dose calculations for thorium-227 and Radium-223, including its daughters, were performed using a

15 software package, 3D-RD-S, recently developed by Radiopharmaceutical Imaging and Dosimetry, LLC

16 (Rapid) that allows accounting for the radiations of all daughter radionuclides. To allow inter-comparison

17 strictly on an absorbed dose basis, an RBE of one was used for all calculations. 


\section{RESULTS}

\section{Human Equivalent TIAC}

3 Table 7 shows the TIAC values obtained by mapping TIAC concentration values from pre-clinical tissues

4 to ICRP and CE phantom source regions.

5 Table 7: Predicted Human TIAC (FIA-h) input for ICRP phantom and CE-Phantom/OLINDA 


\begin{tabular}{|c|c|c|c|c|c|c|}
\hline \multirow{2}{*}{$\begin{array}{l}\text { Source tissue apportionment } \\
\text { Human Tissue (Source Regions) }^{2}\end{array}$} & \multicolumn{2}{|c|}{ CEP } & \multicolumn{2}{|c|}{ Hybrid } & \multicolumn{2}{|c|}{ ICRP } \\
\hline & Th-227 & Ra-223 & Th-227 & Ra-223 & Th-227 & Ra-223 \\
\hline Adrenals & $2.10 \mathrm{E}-01$ & $0.00 \mathrm{E}+00$ & $2.10 \mathrm{E}-01$ & $0.00 \mathrm{E}+00$ & $2.26 \mathrm{E}-01$ & $0.00 \mathrm{E}+00$ \\
\hline Gall bladder content ${ }^{1}$ & $3.10 \mathrm{E}-01$ & $4.00 \mathrm{E}-02$ & $0.00 \mathrm{E}+00$ & $0.00 \mathrm{E}+00$ & $9.49 \mathrm{E}-02$ & $3.20 \mathrm{E}-02$ \\
\hline Red Marrow & $8.50 \mathrm{E}-01$ & $0.00 \mathrm{E}+00$ & $8.50 \mathrm{E}-01$ & $0.00 \mathrm{E}+00$ & $1.06 \mathrm{E}+00$ & $0.00 \mathrm{E}+00$ \\
\hline Cortical bone & $1.36 \mathrm{E}+01$ & $1.92 \mathrm{E}+01$ & $1.36 \mathrm{E}+01$ & $1.92 \mathrm{E}+01$ & $1.52 \mathrm{E}+01$ & $2.14 \mathrm{E}+01$ \\
\hline Brain & $3.36 \mathrm{E}-01$ & $0.00 \mathrm{E}+00$ & $3.36 \mathrm{E}-01$ & $0.00 \mathrm{E}+00$ & $3.59 \mathrm{E}-01$ & $0.00 \mathrm{E}+00$ \\
\hline Gall bladder wall ${ }^{1}$ & $\mathrm{n} / \mathrm{a}$ & $\mathrm{n} / \mathrm{a}$ & $3.10 \mathrm{E}-01$ & $4.00 \mathrm{E}-02$ & $2.17 \mathrm{E}-01$ & $1.14 \mathrm{E}-02$ \\
\hline Heart wall & $1.63 \mathrm{E}+00$ & $1.60 \mathrm{E}-01$ & $1.63 \mathrm{E}+00$ & $1.60 \mathrm{E}-01$ & $1.99 \mathrm{E}+00$ & 1.99E-01 \\
\hline Trabecular bone surface & $3.17 \mathrm{E}+01$ & $2.59 \mathrm{E}+01$ & $3.17 \mathrm{E}+01$ & $2.59 \mathrm{E}+01$ & $3.70 \mathrm{E}+01$ & $3.03 \mathrm{E}+01$ \\
\hline Osteogenic cells & $\mathrm{n} / \mathrm{a}$ & $\mathrm{n} / \mathrm{a}$ & $4.10 \mathrm{E}-01$ & $3.40 \mathrm{E}-01$ & $\mathrm{n} / \mathrm{a}$ & $\mathrm{n} / \mathrm{a}$ \\
\hline Left colon wall & $\mathrm{n} / \mathrm{a}$ & $\mathrm{n} / \mathrm{a}$ & $\mathrm{n} / \mathrm{a}$ & $\mathrm{n} / \mathrm{a}$ & $4.06 \mathrm{E}-01$ & $6.61 \mathrm{E}-01$ \\
\hline Left colon contents & $\mathrm{n} / \mathrm{a}$ & $\mathrm{n} / \mathrm{a}$ & $\mathrm{n} / \mathrm{a}$ & $\mathrm{n} / \mathrm{a}$ & $0.00 \mathrm{E}+00$ & $0.00 \mathrm{E}+00$ \\
\hline Upper large intestine (ULI) wall & $\mathrm{n} / \mathrm{a}$ & $\mathrm{n} / \mathrm{a}$ & $6.70 \mathrm{E}-01$ & $1.10 \mathrm{E}+00$ & $\mathrm{n} / \mathrm{a}$ & $\mathrm{n} / \mathrm{a}$ \\
\hline ULI content & $6.70 \mathrm{E}-01$ & $1.10 \mathrm{E}+00$ & $0.00 \mathrm{E}+00$ & $0.00 \mathrm{E}+00$ & $\mathrm{n} / \mathrm{a}$ & $\mathrm{n} / \mathrm{a}$ \\
\hline Right colon wall & $\mathrm{n} / \mathrm{a}$ & $\mathrm{n} / \mathrm{a}$ & $\mathrm{n} / \mathrm{a}$ & $\mathrm{n} / \mathrm{a}$ & $4.06 \mathrm{E}-01$ & $6.61 \mathrm{E}-01$ \\
\hline Right colon contents & $\mathrm{n} / \mathrm{a}$ & $\mathrm{n} / \mathrm{a}$ & $\mathrm{n} / \mathrm{a}$ & $\mathrm{n} / \mathrm{a}$ & $0.00 \mathrm{E}+00$ & $0.00 \mathrm{E}+00$ \\
\hline Lower large intestine (LLI) wall & $\mathrm{n} / \mathrm{a}$ & $\mathrm{n} / \mathrm{a}$ & $3.90 \mathrm{E}-01$ & $6.30 \mathrm{E}-01$ & $\mathrm{n} / \mathrm{a}$ & $\mathrm{n} / \mathrm{a}$ \\
\hline LLI content & $3.90 \mathrm{E}-01$ & $6.30 \mathrm{E}-01$ & $0.00 \mathrm{E}+00$ & $0.00 \mathrm{E}+00$ & $\mathrm{n} / \mathrm{a}$ & $\mathrm{n} / \mathrm{a}$ \\
\hline Rectosigmoid wall & $\mathrm{n} / \mathrm{a}$ & $\mathrm{n} / \mathrm{a}$ & $\mathrm{n} / \mathrm{a}$ & $\mathrm{n} / \mathrm{a}$ & $8.84 \mathrm{E}-02$ & $1.44 \mathrm{E}-01$ \\
\hline Kidneys & $1.12 \mathrm{E}+01$ & $1.14 \mathrm{E}+00$ & $1.12 \mathrm{E}+01$ & $1.14 \mathrm{E}+00$ & $1.58 \mathrm{E}+01$ & $1.61 \mathrm{E}+00$ \\
\hline Liver & $3.37 \mathrm{E}+02$ & $3.83 \mathrm{E}+01$ & $3.37 \mathrm{E}+02$ & $3.83 \mathrm{E}+01$ & $4.16 \mathrm{E}+02$ & $4.73 \mathrm{E}+01$ \\
\hline Lungs; Lung Tissue & $7.10 \mathrm{E}+00$ & $4.50 \mathrm{E}-01$ & $7.10 \mathrm{E}+00$ & $4.50 \mathrm{E}-01$ & $8.52 \mathrm{E}+00$ & $5.43 \mathrm{E}-01$ \\
\hline Extra-thoracic Lymph nodes & $\mathrm{n} / \mathrm{a}$ & $\mathrm{n} / \mathrm{a}$ & $\mathrm{n} / \mathrm{a}$ & $\mathrm{n} / \mathrm{a}$ & $9.46 \mathrm{E}-02$ & $0.00 \mathrm{E}+00$ \\
\hline Muscle & $7.70 \mathrm{E}+00$ & $0.00 \mathrm{E}+00$ & $7.70 \mathrm{E}+00$ & $0.00 \mathrm{E}+00$ & $8.19 \mathrm{E}+00$ & $0.00 \mathrm{E}+00$ \\
\hline Pancreas & 4.30E-01 & $2.00 \mathrm{E}-02$ & $4.30 \mathrm{E}-01$ & $2.00 \mathrm{E}-02$ & 7.97E-01 & $3.47 \mathrm{E}-02$ \\
\hline Prostate & $\mathrm{n} / \mathrm{a}$ & $\mathrm{n} / \mathrm{a}$ & $\mathrm{n} / \mathrm{a}$ & $\mathrm{n} / \mathrm{a}$ & $1.79 \mathrm{E}-01$ & $0.00 \mathrm{E}+00$ \\
\hline Testes & $1.40 \mathrm{E}-01$ & $1.00 \mathrm{E}-02$ & $1.40 \mathrm{E}-01$ & $1.00 \mathrm{E}-02$ & $1.29 \mathrm{E}-01$ & $5.09 \mathrm{E}-03$ \\
\hline Small intestine & $7.22 \mathrm{E}+00$ & $4.89 \mathrm{E}+00$ & & & & \\
\hline Small intestine wall ${ }^{3}$ & $\mathrm{n} / \mathrm{a}$ & $\mathrm{n} / \mathrm{a}$ & $7.22 \mathrm{E}+00$ & $4.89 \mathrm{E}+00$ & $8.62 \mathrm{E}+00$ & $5.85 \mathrm{E}+00$ \\
\hline Spleen & $4.83 \mathrm{E}+00$ & $6.00 \mathrm{E}-01$ & $4.83 \mathrm{E}+00$ & $6.00 \mathrm{E}-01$ & $6.03 \mathrm{E}+00$ & $7.52 \mathrm{E}-01$ \\
\hline Thyroid & $1.20 \mathrm{E}-02$ & $0.00 \mathrm{E}+00$ & $1.20 \mathrm{E}-02$ & $0.00 \mathrm{E}+00$ & $1.33 \mathrm{E}-02$ & $0.00 \mathrm{E}+00$ \\
\hline
\end{tabular}




\footnotetext{
${ }^{1}$ Human-equivalent TIAC for gallbladder and bile (GB) derived from Table 4 was assigned to GB contents in the CEP calculation since the CEP phantom does not list GB wall as a source region; in the hybrid calculations, TIAC for GB was assigned to GB wall.

${ }^{2} \mathrm{n} / \mathrm{a}$ : Source region not defined in the phantom used for respective method.

${ }^{3} \mathrm{CEP}$ and hybrid do not distinguish between wall and contents for small intestine region.
}

\section{Absorbed Doses}

2 Table 8 through 11 list, respectively, the photon, beta particle, $\alpha$-particle and total specific absorbed dose

3 calculated using the three different methods. The photon, beta particle, $\alpha$-particle and total specific absorbed

4 doses are plotted in Figure 7-11, respectively.

5 Table 8: Photon doses calculated using the CEP, Hybrid, and ICRP methods $(\mathrm{mGy} / \mathrm{kBq}, \mathrm{RBE}=1)$

\begin{tabular}{|c|c|c|c|c|}
\hline \multirow[b]{2}{*}{ Target Tissue $^{1}$} & \multicolumn{2}{|c|}{ CEP/Hybrid } & \multicolumn{2}{|c|}{ ICRP } \\
\hline & Th-227 & $\begin{array}{l}\text { Ra-223 + } \\
\text { Daughters }\end{array}$ & Th-227 & $\begin{array}{c}\text { Ra-223 + } \\
\text { Daughters }\end{array}$ \\
\hline adrenals & 5.29E-04 & $1.94 \mathrm{E}-04$ & $1.42 \mathrm{E}-03$ & $4.00 \mathrm{E}-04$ \\
\hline $\begin{array}{l}\text { Lungs (CEP, } \\
\text { hybrid)/AI (ICRP) }\end{array}$ & $2.50 \mathrm{E}-04$ & $9.76 \mathrm{E}-05$ & $5.62 \mathrm{E}-04$ & $1.85 \mathrm{E}-04$ \\
\hline Brain & $2.20 \mathrm{E}-05$ & $4.86 \mathrm{E}-05$ & $3.39 \mathrm{E}-05$ & $6.21 \mathrm{E}-05$ \\
\hline $\begin{array}{l}\text { Osteogenic cells (CEP, } \\
\text { hybrid)/endost-bs } \\
\text { (ICRP) }\end{array}$ & $1.75 \mathrm{E}-04$ & $1.97 \mathrm{E}-04$ & $7.36 \mathrm{E}-04$ & $1.07 \mathrm{E}-03$ \\
\hline gb-wall & $9.08 \mathrm{E}-04$ & $3.21 \mathrm{E}-04$ & $2.91 \mathrm{E}-03$ & $7.68 \mathrm{E}-04$ \\
\hline ht-wall & $2.80 \mathrm{E}-04$ & $1.06 \mathrm{E}-04$ & $6.17 \mathrm{E}-04$ & $1.96 \mathrm{E}-04$ \\
\hline kidneys & $5.41 \mathrm{E}-04$ & $1.87 \mathrm{E}-04$ & $1.13 \mathrm{E}-03$ & $3.15 \mathrm{E}-04$ \\
\hline $\begin{array}{l}\text { ULI wall (CEP, } \\
\text { hybrid)/ lc-stem } \\
\text { (ICRP) }\end{array}$ & $2.38 \mathrm{E}-04$ & $1.68 \mathrm{E}-04$ & $2.88 \mathrm{E}-04$ & $1.54 \mathrm{E}-04$ \\
\hline liver & $2.16 \mathrm{E}-03$ & $6.66 \mathrm{E}-04$ & $3.18 \mathrm{E}-03$ & $7.19 \mathrm{E}-04$ \\
\hline ln-et & & & $1.14 \mathrm{E}-04$ & $6.03 \mathrm{E}-05$ \\
\hline muscle & $1.00 \mathrm{E}-04$ & $6.21 \mathrm{E}-05$ & $1.12 \mathrm{E}-04$ & $6.69 \mathrm{E}-05$ \\
\hline pancreas & $4.51 \mathrm{E}-04$ & $1.64 \mathrm{E}-04$ & $1.35 \mathrm{E}-03$ & $4.20 \mathrm{E}-04$ \\
\hline prostate & & & $1.04 \mathrm{E}-04$ & $6.24 \mathrm{E}-05$ \\
\hline
\end{tabular}




\begin{tabular}{|l|c|c|c|c|}
\hline r-marrow & $1.35 \mathrm{E}-04$ & $1.21 \mathrm{E}-04$ & $3.26 \mathrm{E}-04$ & $2.14 \mathrm{E}-04$ \\
\hline $\begin{array}{l}\text { LLI-wall (CEP, } \\
\text { hybrid)/rc-stem (ICRP) }\end{array}$ & $5.06 \mathrm{E}-05$ & $8.16 \mathrm{E}-05$ & $6.64 \mathrm{E}-04$ & $2.52 \mathrm{E}-04$ \\
\hline rs-stem & & & $6.06 \mathrm{E}-05$ & $8.19 \mathrm{E}-05$ \\
\hline $\begin{array}{l}\text { si-wall (hybrid)/si-stem } \\
\text { (ICRP) }\end{array}$ & $1.67 \mathrm{E}-04$ & $1.30 \mathrm{E}-04$ & $3.40 \mathrm{E}-04$ & $1.83 \mathrm{E}-04$ \\
\hline spleen & $2.82 \mathrm{E}-04$ & $1.08 \mathrm{E}-04$ & $5.50 \mathrm{E}-04$ & $1.72 \mathrm{E}-04$ \\
\hline thyroid & $2.83 \mathrm{E}-05$ & $3.43 \mathrm{E}-05$ & $1.05 \mathrm{E}-04$ & $6.70 \mathrm{E}-05$ \\
\hline
\end{tabular}

${ }^{1}$ Refer to Appendix 1 (Table 3 ) for full name of target region acronyms mentioned in table and plot

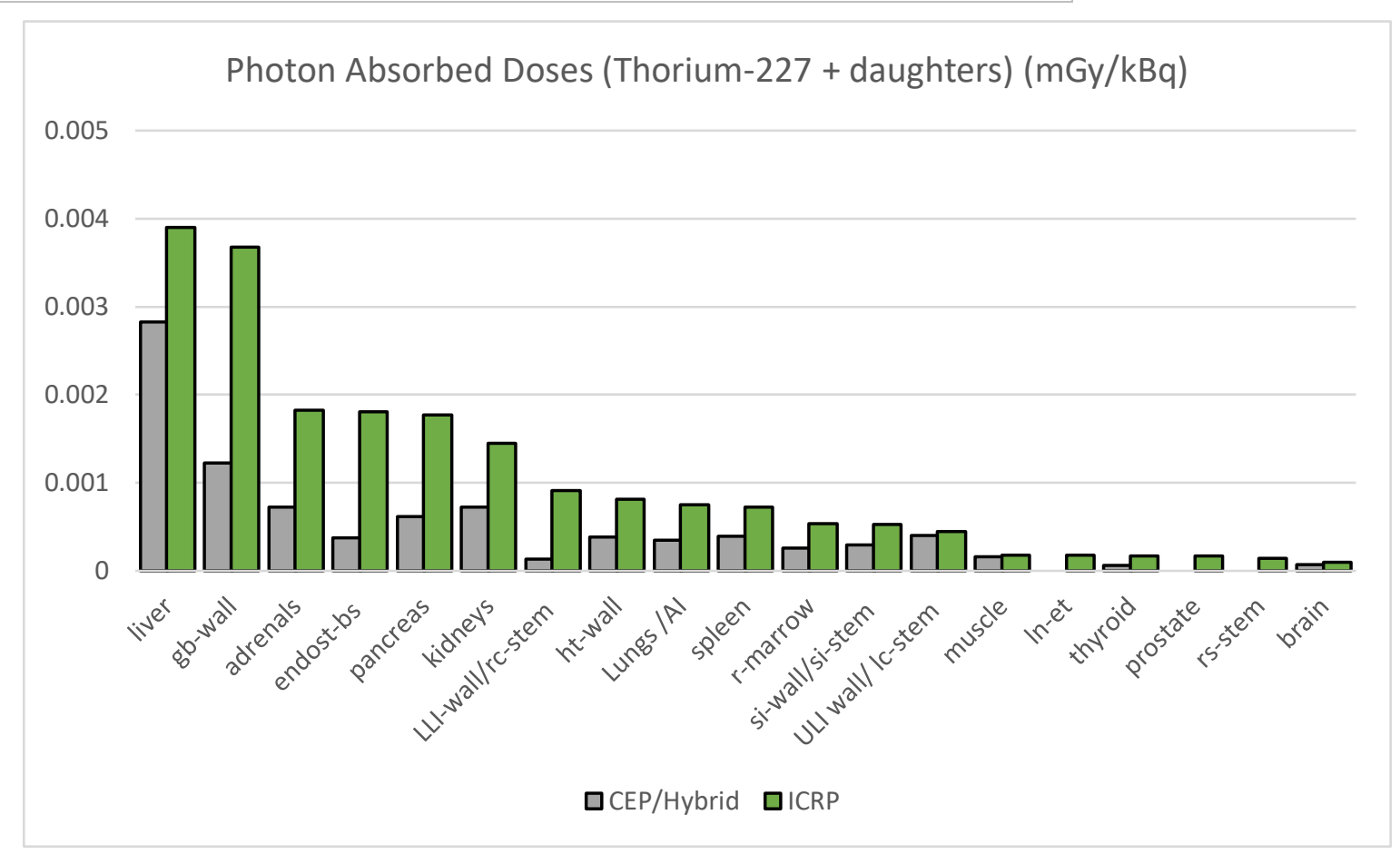

Figure 7: Comparison between photon doses computed from CEP, Hybrid and ICRP

3 Table 9: Beta and electron doses calculated using the CEP, Hybrid, and ICRP methods in $(\mathrm{mGY} / \mathrm{kBq}, \mathrm{RBE}=$ 4 1)

\begin{tabular}{|c|c|c|c|c|}
\hline \multirow[b]{2}{*}{ Target Tissue $^{1}$} & \multicolumn{2}{|c|}{ CEP/Hybrid } & \multicolumn{2}{|c|}{ ICRP } \\
\hline & Th-227 & $\begin{array}{c}\text { Ra-223 + } \\
\text { Daughters }\end{array}$ & Th-227 & $\begin{array}{c}\text { Ra-223 + } \\
\text { Daughters }\end{array}$ \\
\hline adrenals & $2.13 \mathrm{E}-04$ & $0.00 \mathrm{E}+00$ & $5.73 \mathrm{E}-04$ & $3.22 \mathrm{E}-04$ \\
\hline
\end{tabular}




\begin{tabular}{|c|c|c|c|c|}
\hline $\begin{array}{l}\text { lungs (CEP, hybrid)/AI } \\
\text { (ICRP) }\end{array}$ & $1.16 \mathrm{E}-04$ & $2.70 \mathrm{E}-04$ & $3.26 \mathrm{E}-04$ & $3.49 \mathrm{E}-04$ \\
\hline brain & $3.88 \mathrm{E}-06$ & $0.00 \mathrm{E}+00$ & $1.06 \mathrm{E}-05$ & $6.04 \mathrm{E}-05$ \\
\hline $\begin{array}{l}\text { osteogenic cells (CEP, } \\
\text { hybrid)/endost-bs (ICRP) }\end{array}$ & $1.39 \mathrm{E}-03$ & $9.44 \mathrm{E}-03$ & $1.14 \mathrm{E}-03$ & 4.71E-03 \\
\hline gb-wall & 4.59E-05 & $2.26 \mathrm{E}-04$ & $9.91 \mathrm{E}-04$ & $2.63 \mathrm{E}-03$ \\
\hline ht-wall & $8.42 \mathrm{E}-05$ & $3.07 \mathrm{E}-04$ & $2.22 \mathrm{E}-04$ & $2.83 \mathrm{E}-04$ \\
\hline kidneys & $6.11 \mathrm{E}-04$ & $2.26 \mathrm{E}-03$ & $1.62 \mathrm{E}-03$ & $2.22 \mathrm{E}-03$ \\
\hline $\begin{array}{l}\text { ULI wall (CEP, hybrid)/ lc- } \\
\text { stem (ICRP) }\end{array}$ & $2.37 \mathrm{E}-05$ & $1.40 \mathrm{E}-03$ & $8.78 \mathrm{E}-05$ & $1.46 \mathrm{E}-03$ \\
\hline liver & $2.89 \mathrm{E}-03$ & $1.20 \mathrm{E}-02$ & $7.66 \mathrm{E}-03$ & $1.18 \mathrm{E}-02$ \\
\hline $\begin{array}{l}\text { Extra-thoracic lymph nodes } \\
\text { (ln-et) }\end{array}$ & & & $2.55 \mathrm{E}-04$ & $6.81 \mathrm{E}-05$ \\
\hline muscle & 4.50E-06 & $0.00 \mathrm{E}+00$ & $1.22 \mathrm{E}-05$ & $4.44 \mathrm{E}-05$ \\
\hline pancreas & 7.51E-05 & $1.18 \mathrm{E}-04$ & $2.01 \mathrm{E}-04$ & $2.00 \mathrm{E}-04$ \\
\hline prostate & & & 4.34E-04 & $7.42 \mathrm{E}-07$ \\
\hline r-marrow & 1.10E-04 & $3.80 \mathrm{E}-03$ & $2.24 \mathrm{E}-04$ & $2.83 \mathrm{E}-03$ \\
\hline $\begin{array}{l}\text { LLI-wall (CEP, hybrid)/rc- } \\
\text { stem (ICRP) }\end{array}$ & $2.22 \mathrm{E}-05$ & $1.30 \mathrm{E}-03$ & $8.89 \mathrm{E}-05$ & $1.49 \mathrm{E}-03$ \\
\hline $\begin{array}{l}\text { Rectosigmoid stem cell layer } \\
\text { (rs-stem) }\end{array}$ & & & $4.09 \mathrm{E}-05$ & $6.50 \mathrm{E}-04$ \\
\hline $\begin{array}{l}\text { si-wall (hybrid)/si-stem } \\
\text { (ICRP) }\end{array}$ & $1.40 \mathrm{E}-04$ & $3.43 \mathrm{E}-03$ & 4.17E-04 & $2.74 \mathrm{E}-03$ \\
\hline spleen & $4.32 \mathrm{E}-04$ & $1.95 \mathrm{E}-03$ & $1.14 \mathrm{E}-03$ & $1.89 \mathrm{E}-03$ \\
\hline thyroid & $9.33 \mathrm{E}-06$ & $0.00 \mathrm{E}+00$ & $2.46 \mathrm{E}-05$ & $6.97 \mathrm{E}-07$ \\
\hline
\end{tabular}




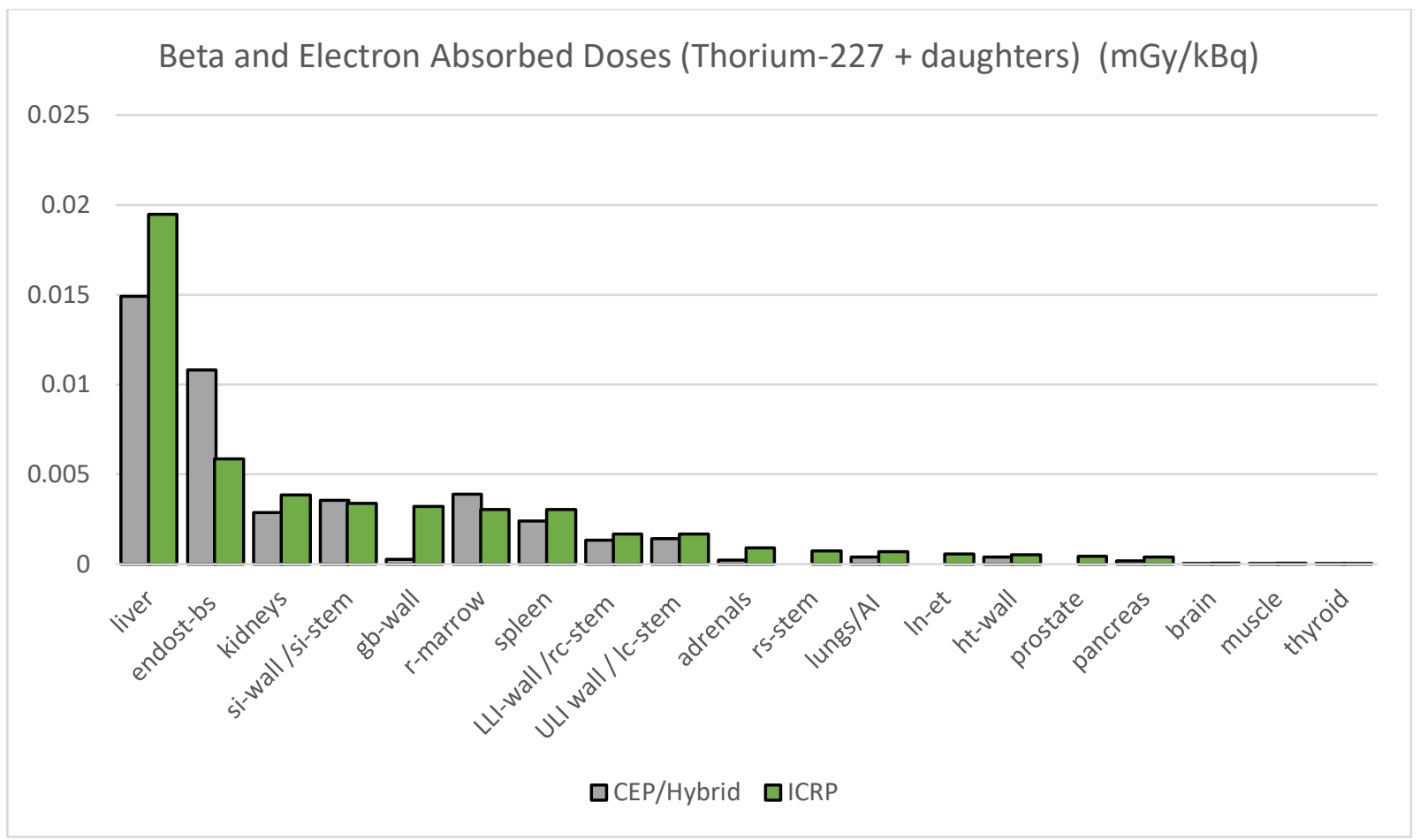

Figure 8: Comparison between the sum of beta-particle and electron absorbed doses calculated using the CEP, Hybrid and ICRP methods.

4 Table 10: Alpha radiation calculated across CEP, Hybrid and ICRP $(\mathrm{mGy} / \mathrm{kBq}, \mathrm{RBE}=1)$

\begin{tabular}{|c|c|c|c|c|c|c|}
\hline \multirow[b]{2}{*}{ Target Tissue $^{1}$} & \multicolumn{2}{|c|}{ CEP } & \multicolumn{2}{|c|}{ Hybrid } & \multicolumn{2}{|c|}{ ICRP } \\
\hline & Th-227 & $\begin{array}{l}\text { Ra-223 + } \\
\text { Daughters }\end{array}$ & Th-227 & $\begin{array}{l}\text { Ra }-223+ \\
\text { Daughters }\end{array}$ & Th-227 & $\begin{array}{c}\text { Ra-223 + } \\
\text { Daughters }\end{array}$ \\
\hline adrenals & $4.42 \mathrm{E}-02$ & $0.00 \mathrm{E}+00$ & $4.42 \mathrm{E}-02$ & $0.00 \mathrm{E}+00$ & $4.42 \mathrm{E}-02$ & $0.00 \mathrm{E}+00$ \\
\hline $\begin{array}{l}\text { lungs (CEP, hybrid)/AI } \\
\text { (ICRP) }\end{array}$ & $2.42 \mathrm{E}-02$ & $6.91 \mathrm{E}-03$ & $2.41 \mathrm{E}-02$ & $6.88 \mathrm{E}-03$ & $2.50 \mathrm{E}-02$ & $7.14 \mathrm{E}-03$ \\
\hline brain & $8.06 \mathrm{E}-04$ & $0.00 \mathrm{E}+00$ & $8.03 \mathrm{E}-04$ & $0.00 \mathrm{E}+00$ & 8.03E-04 & $0.00 \mathrm{E}+00$ \\
\hline $\begin{array}{l}\text { osteogenic cells (CEP, } \\
\text { hybrid)/endost-bs (ICRP) }\end{array}$ & $5.76 \mathrm{E}-01$ & $2.49 \mathrm{E}+00$ & $2.12 \mathrm{E}-01$ & $5.00 \mathrm{E}-01$ & $1.15 \mathrm{E}-01$ & $4.25 \mathrm{E}-01$ \\
\hline gb-wall & $9.56 \mathrm{E}-03$ & $5.90 \mathrm{E}-03$ & $1.01 \mathrm{E}-01$ & $6.23 \mathrm{E}-02$ & 7.03E-02 & $1.66 \mathrm{E}-02$ \\
\hline ht-wall & $1.75 \mathrm{E}-02$ & $7.90 \mathrm{E}-03$ & $1.75 \mathrm{E}-02$ & $7.85 \mathrm{E}-03$ & $1.74 \mathrm{E}-02$ & $7.85 \mathrm{E}-03$ \\
\hline kidneys & $1.27 \mathrm{E}-01$ & $5.81 \mathrm{E}-02$ & $1.27 \mathrm{E}-01$ & $5.80 \mathrm{E}-02$ & $1.27 \mathrm{E}-01$ & $5.79 \mathrm{E}-02$ \\
\hline $\begin{array}{l}\text { ULI wall (CEP, hybrid)/ lc- } \\
\text { stem (ICRP) }\end{array}$ & 4.94E-03 & $3.61 \mathrm{E}-02$ & $1.04 \mathrm{E}-02$ & 7.61E-02 & $6.89 \mathrm{E}-03$ & $5.03 \mathrm{E}-02$ \\
\hline liver & $6.00 \mathrm{E}-01$ & $3.06 \mathrm{E}-01$ & $5.99 \mathrm{E}-01$ & $3.05 \mathrm{E}-01$ & $5.99 \mathrm{E}-01$ & $3.05 \mathrm{E}-01$ \\
\hline
\end{tabular}




\begin{tabular}{|c|c|c|c|c|c|c|}
\hline ln-et & & & & & $2.01 \mathrm{E}-02$ & $0.00 \mathrm{E}+00$ \\
\hline muscle & $9.36 \mathrm{E}-04$ & $0.00 \mathrm{E}+00$ & $9.34 \mathrm{E}-04$ & $0.00 \mathrm{E}+00$ & $9.33 \mathrm{E}-04$ & $0.00 \mathrm{E}+00$ \\
\hline pancreas & $1.56 \mathrm{E}-02$ & $3.05 \mathrm{E}-03$ & $1.56 \mathrm{E}-02$ & $3.04 \mathrm{E}-03$ & $1.56 \mathrm{E}-02$ & $3.04 \mathrm{E}-03$ \\
\hline prostate & & & & & $3.41 \mathrm{E}-02$ & $0.00 \mathrm{E}+00$ \\
\hline r-marrow & $5.08 \mathrm{E}-02$ & $1.77 \mathrm{E}-01$ & $2.24 \mathrm{E}-02$ & $5.77 \mathrm{E}-02$ & $1.62 \mathrm{E}-02$ & $5.40 \mathrm{E}-02$ \\
\hline $\begin{array}{l}\text { LLI-wall (CEP, hybrid)/rc- } \\
\text { stem (ICRP) }\end{array}$ & $4.62 \mathrm{E}-03$ & $3.37 \mathrm{E}-02$ & 7.89E-03 & $5.75 \mathrm{E}-02$ & $6.89 \mathrm{E}-03$ & $5.03 \mathrm{E}-02$ \\
\hline rs-stem & & & & & $3.22 \mathrm{E}-03$ & $2.35 \mathrm{E}-02$ \\
\hline $\begin{array}{l}\text { si-wall (hybrid)/si-stem } \\
\text { (ICRP) }\end{array}$ & $2.90 \mathrm{E}-02$ & 8.83E-02 & $3.62 \mathrm{E}-02$ & $1.10 \mathrm{E}-01$ & 3.39E-02 & $1.03 \mathrm{E}-01$ \\
\hline spleen & $8.98 \mathrm{E}-02$ & $5.03 \mathrm{E}-02$ & $8.96 \mathrm{E}-02$ & $5.02 \mathrm{E}-02$ & $8.96 \mathrm{E}-02$ & $5.01 \mathrm{E}-02$ \\
\hline thyroid & $1.94 \mathrm{E}-03$ & $0.00 \mathrm{E}+00$ & $1.94 \mathrm{E}-03$ & $0.00 \mathrm{E}+00$ & $1.94 \mathrm{E}-03$ & $0.00 \mathrm{E}+00$ \\
\hline
\end{tabular}

${ }^{1}$ Refer to Appendix 1 (Table 3 ) for full name of target region acronyms mentioned in table and plot

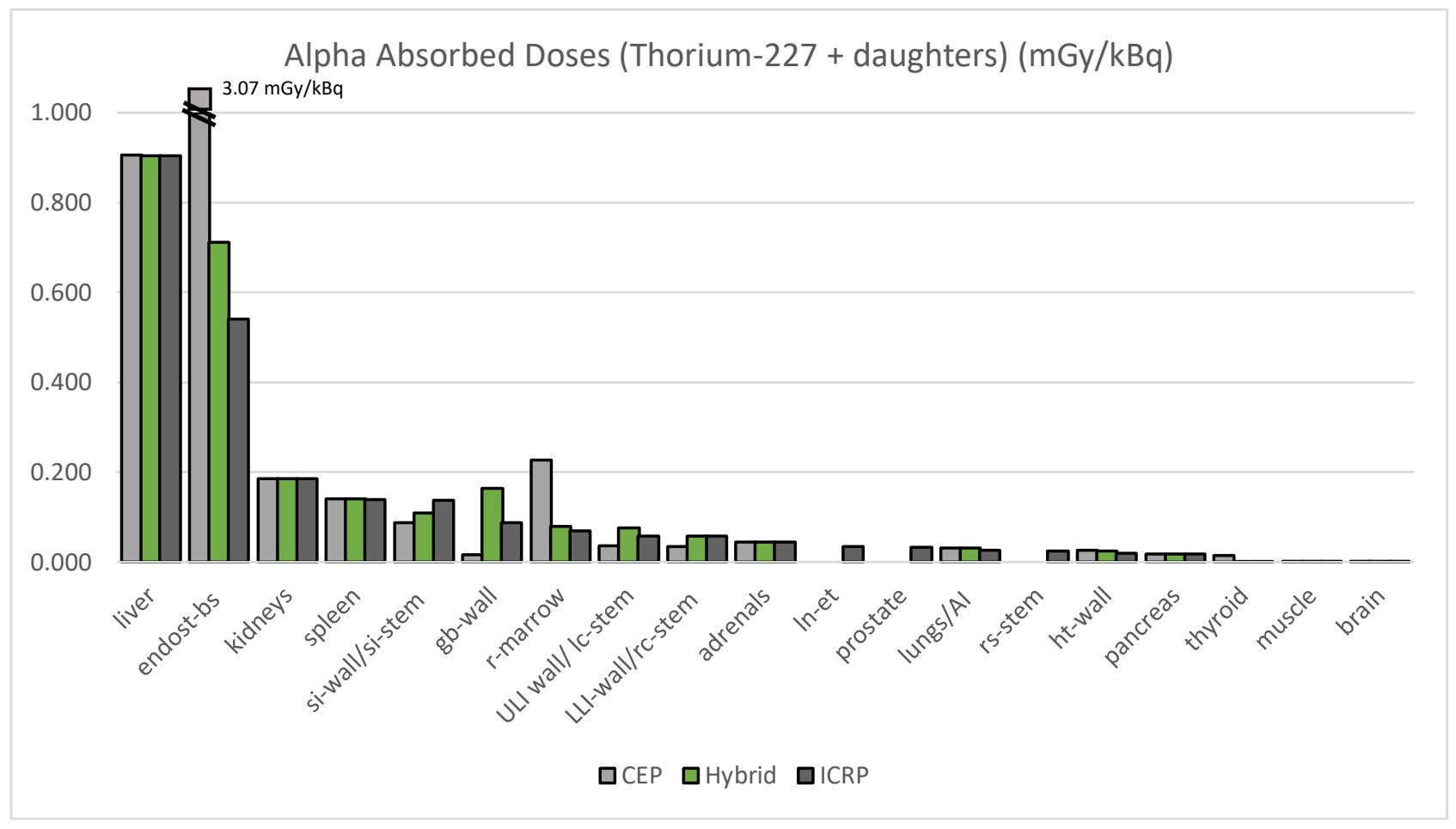

2 Figure 9: Alpha particle absorbed dose comparisons across CEP (calculated using OLINDA), Hybrid, and 
1 Table 11: Total Specific absorbed doses calculated using the CEP, Hybrid, and ICRP methods ( $\mathrm{mGy} / \mathrm{kBq}$,

$2 \quad \mathrm{RBE}=1)$

\begin{tabular}{|c|c|c|c|c|c|c|}
\hline \multirow[b]{2}{*}{ Target Tissue $^{2}$} & \multicolumn{2}{|c|}{ CEP' } & \multicolumn{2}{|c|}{ Hybrid } & \multicolumn{2}{|c|}{ ICRP } \\
\hline & Th-227 & $\begin{array}{l}\text { Ra-223 + } \\
\text { Daughters }\end{array}$ & Th-227 & $\begin{array}{c}\text { Ra-223 + } \\
\text { Daughters }\end{array}$ & Th-227 & $\begin{array}{c}\text { Ra-223+ } \\
\text { Daughter } \\
\text { s }\end{array}$ \\
\hline adrenals & $4.49 \mathrm{E}-02$ & $1.94 \mathrm{E}-04$ & $4.49 \mathrm{E}-02$ & $1.94 \mathrm{E}-04$ & $4.61 \mathrm{E}-02$ & $7.23 \mathrm{E}-04$ \\
\hline $\begin{array}{l}\text { lungs (CEP, hybrid)/AI } \\
\text { (ICRP) }\end{array}$ & $2.46 \mathrm{E}-02$ & $7.28 \mathrm{E}-03$ & $2.45 \mathrm{E}-02$ & $7.25 \mathrm{E}-03$ & $2.59 \mathrm{E}-02$ & $7.68 \mathrm{E}-03$ \\
\hline brain & $8.32 \mathrm{E}-04$ & $4.86 \mathrm{E}-05$ & $8.29 \mathrm{E}-04$ & $4.86 \mathrm{E}-05$ & $8.48 \mathrm{E}-04$ & $1.22 \mathrm{E}-04$ \\
\hline $\begin{array}{l}\text { osteogenic cells (CEP, } \\
\text { hybrid)/endost-bs (ICRP) }\end{array}$ & $5.78 \mathrm{E}-01$ & $2.50 \mathrm{E}+00$ & $2.13 \mathrm{E}-01$ & $5.10 \mathrm{E}-01$ & $1.17 \mathrm{E}-01$ & $4.31 \mathrm{E}-01$ \\
\hline gb-wall ${ }^{3}$ & $1.05 \mathrm{E}-02$ & $6.45 \mathrm{E}-03$ & $1.02 \mathrm{E}-01$ & $6.29 \mathrm{E}-02$ & 7.42E-02 & $2.00 \mathrm{E}-02$ \\
\hline ht-wall & $1.79 \mathrm{E}-02$ & $8.31 \mathrm{E}-03$ & $1.79 \mathrm{E}-02$ & $8.27 \mathrm{E}-03$ & $1.83 \mathrm{E}-02$ & $8.33 \mathrm{E}-03$ \\
\hline kidneys & $1.28 \mathrm{E}-01$ & $6.06 \mathrm{E}-02$ & $1.28 \mathrm{E}-01$ & $6.05 \mathrm{E}-02$ & $1.30 \mathrm{E}-01$ & $6.04 \mathrm{E}-02$ \\
\hline $\begin{array}{l}\text { ULI wall (CEP, hybrid)/ lc- } \\
\text { stem (ICRP) }\end{array}$ & $5.20 \mathrm{E}-03$ & $3.76 \mathrm{E}-02$ & $1.06 \mathrm{E}-02$ & 7.77E-02 & 7.27E-03 & $5.19 \mathrm{E}-02$ \\
\hline liver & $6.05 \mathrm{E}-01$ & $3.19 \mathrm{E}-01$ & $6.04 \mathrm{E}-01$ & $3.18 \mathrm{E}-01$ & $6.09 \mathrm{E}-01$ & $3.18 \mathrm{E}-01$ \\
\hline ln-et & & & & & $2.05 \mathrm{E}-02$ & $1.28 \mathrm{E}-04$ \\
\hline muscle & $1.04 \mathrm{E}-03$ & $6.21 \mathrm{E}-05$ & $1.04 \mathrm{E}-03$ & $6.21 \mathrm{E}-05$ & $1.06 \mathrm{E}-03$ & $1.11 \mathrm{E}-04$ \\
\hline pancreas & $1.61 \mathrm{E}-02$ & $3.33 \mathrm{E}-03$ & $1.61 \mathrm{E}-02$ & $3.32 \mathrm{E}-03$ & $1.71 \mathrm{E}-02$ & $3.66 \mathrm{E}-03$ \\
\hline prostate & & & & & $3.46 \mathrm{E}-02$ & $6.31 \mathrm{E}-05$ \\
\hline r-marrow & $5.10 \mathrm{E}-02$ & $1.81 \mathrm{E}-01$ & $2.26 \mathrm{E}-02$ & $6.16 \mathrm{E}-02$ & $1.68 \mathrm{E}-02$ & $5.71 \mathrm{E}-02$ \\
\hline $\begin{array}{l}\text { LLI-wall (CEP, hybrid)/rc- } \\
\text { stem (ICRP) }\end{array}$ & $4.69 \mathrm{E}-03$ & $3.51 \mathrm{E}-02$ & $7.96 \mathrm{E}-03$ & 5.89E-02 & 7.64E-03 & $5.20 \mathrm{E}-02$ \\
\hline rs-stem & & & & & $3.32 \mathrm{E}-03$ & $2.42 \mathrm{E}-02$ \\
\hline $\begin{array}{l}\text { si-wall (hybrid)/si-stem } \\
\text { (ICRP) }\end{array}$ & $2.93 \mathrm{E}-02$ & $9.19 \mathrm{E}-02$ & $3.65 \mathrm{E}-02$ & $1.14 \mathrm{E}-01$ & $3.46 \mathrm{E}-02$ & $1.06 \mathrm{E}-01$ \\
\hline spleen & $9.05 \mathrm{E}-02$ & $5.24 \mathrm{E}-02$ & $9.03 \mathrm{E}-02$ & $5.22 \mathrm{E}-02$ & $9.13 \mathrm{E}-02$ & $5.22 \mathrm{E}-02$ \\
\hline thyroid & $1.98 \mathrm{E}-03$ & $3.43 \mathrm{E}-05$ & $1.97 \mathrm{E}-03$ & $3.43 \mathrm{E}-05$ & $2.07 \mathrm{E}-03$ & $6.77 \mathrm{E}-05$ \\
\hline $\begin{array}{l}{ }^{1} \text { Calculated using OLINDA } \\
{ }^{2} \text { Refer to Appendix } 1 \text { (Table } \\
{ }^{3} \text { CEP does not have wall regi } \\
\text { assigns CEP TIAC value to v }\end{array}$ & $\begin{array}{l}\text { for full nar } \\
\text {; ICRP ass }\end{array}$ & of target re & $\begin{array}{l}\text { ion acronyn } \\
3 \text { contents }\end{array}$ & mentioned $\mathrm{i}$ & $\begin{array}{l}\text { table and } \\
\text { ch a source }\end{array}$ & hybrid \\
\hline
\end{tabular}




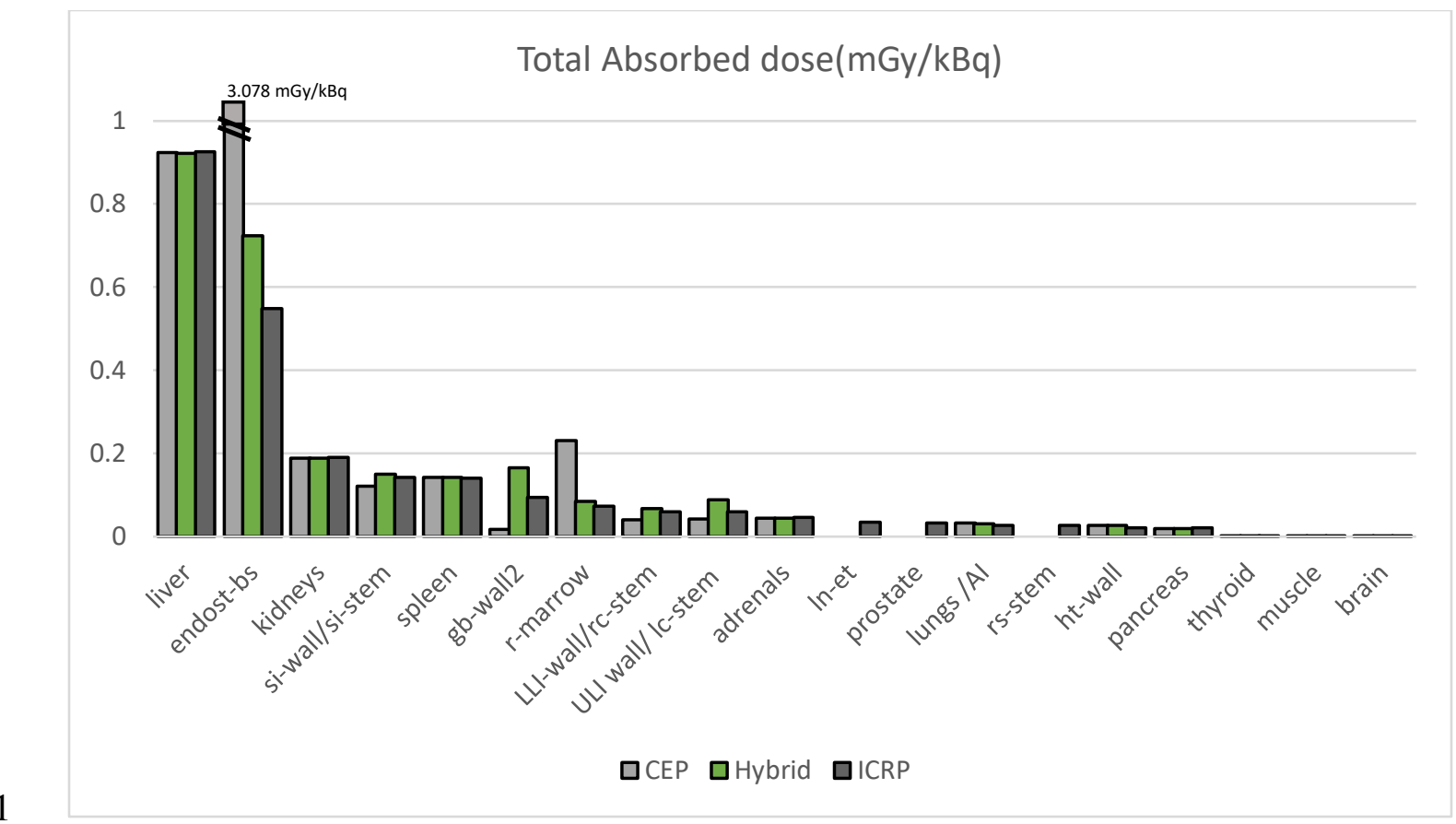

Figure 10: Total Specific Absorbed Doses calculated using CEP, Hybrid and ICRP

\section{DISCUSSION}

4 Dosimetry as part of a treatment planning, individualized to a patient or group of patients with similar

5 characteristics, approach to RPT can be implemented only after rigorous clinical studies have demonstrated

6 patient benefit. Before such studies are initiated, the following must be in place:

1. Standardized, well-validated quantitative imaging and dosimetry techniques

2. Methods that reduce the logistical burden (i.e., reduce number of acquisitions required for a given agent) on patients while also preserving accuracy

3. Reporting that includes an assessment of the accuracy of the calculation (e.g., standard deviation of the reported absorbed dose results)

12 This work addresses the first item as it relates to dosimetry. If, for a given input data set, the results of a

13 dosimetry calculation are not the same everywhere (I.e., with the same level of accuracy), the argument for

14 adopting RPT dosimetry and treatment planning anywhere is difficult to make. The benefits of dosimetry 
1 driven RPT treatment planning will be difficult if not impossible to demonstrate if absorbed doses and

2 corresponding patient outcomes are not comparable wherever RPT is implemented. At present, dosimetry

3 calculations for radiopharmaceuticals are performed, for the most part, with $\mathrm{S}$ values derived from absorbed

4 fractions calculated using phantoms developed in the late 70's through the 80's (i.e., the Cristy-Eckerman

5 Phantoms, and modifications thereof, as implemented in OLINDA v1). The absorbed fractions calculated

6 using these phantoms focused primarily on photon transport; the dose contribution from electrons was set

7 either to 1 (organ self-dose) or zero (cross-organ dose). The absorbed dose contribution to wall from

8 contents was set to 0.5 of the content self-irradiation absorbed dose. To address the increasing use of alpha-

9 particle emitting radiopharmaceuticals for therapy, absorbed fractions for alpha-particles were calculated

10 and incorporated into S-values for alpha-particle emitters that are used in OLINDA. In 2017, the ICRP

11 released new and much more realistic phantoms [18]. These were generated by segmenting patient CT

12 scans. The specific absorbed fractions calculated using these new phantom geometries include both electron

13 and alpha-particle transport (using stylized models for selected tissue). As Figure 11 shows, there are

14 substantial differences in anatomical realism between the two phantom types. 


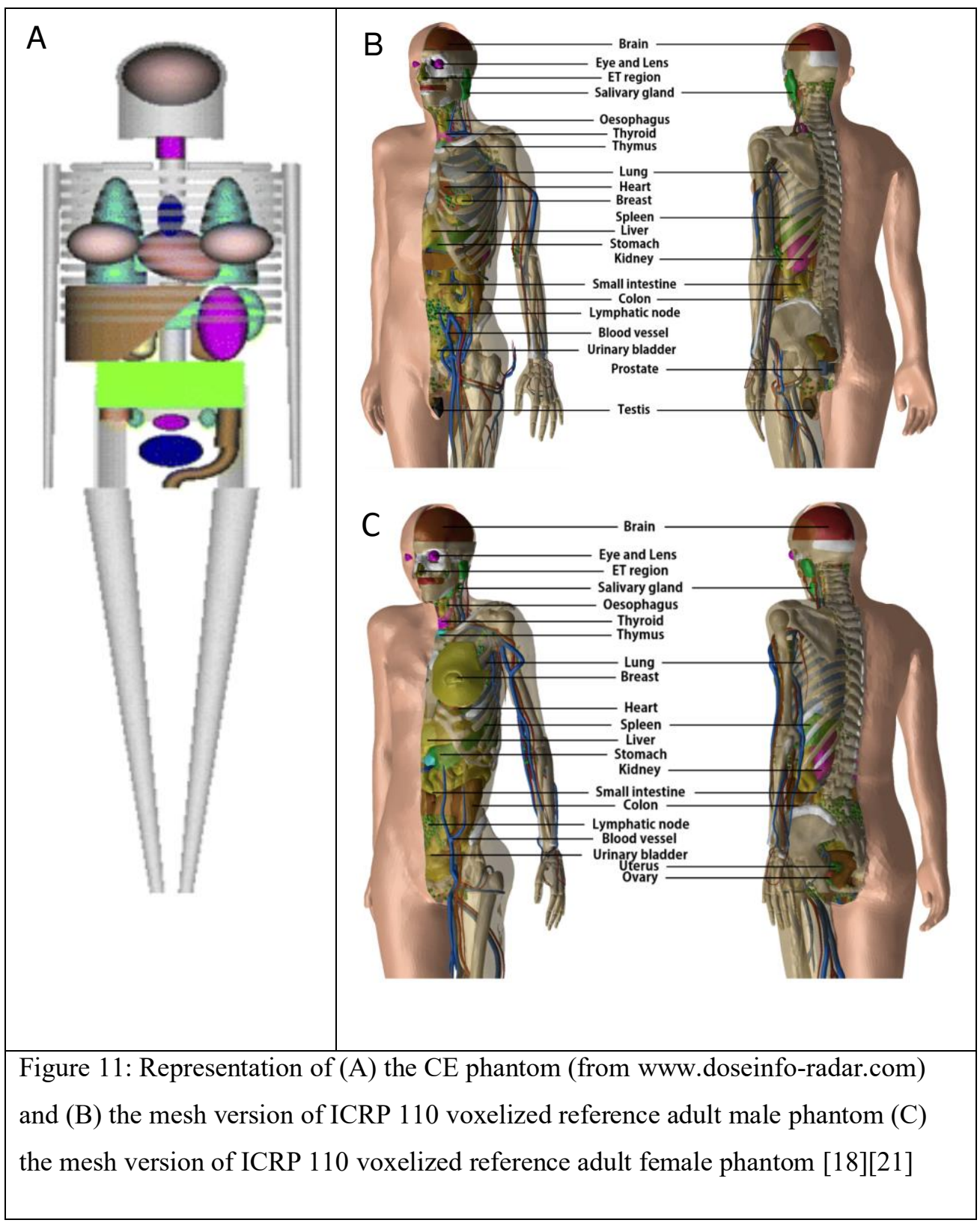

1 Despite the better anatomical representation and improved accuracy, calculations using these new phantoms

2 have not been widely adopted. The comparisons provided in this work are intended to help transition the

3 field to these new models, which are anatomically and computationally more accurate. As a first step, we

4 established a correspondence between CEP and ICRP phantom source/target tissue nomenclature (Figure

5 1-6). We have also endeavored to identify tissue mass differences and use these to provide guidance on

6 how to apportion TIAC originally derived for CEP anatomic geometry (Table 1, Appendix). 
1 We described 3 different calculation methodologies. The first two are based on the CE phantoms; they

2 differ in how alpha particle absorbed dose is calculated. This was done because the provenance of alpha-

3 particle $\mathrm{S}$ values used in OLINDA has not been established. Accordingly, the second methodology (hybrid)

4 explicitly describes how alpha particle energy was apportioned in the calculations, making it possible to

5 understand and interpret differences in the alpha-particle contributions to the absorbed dose. In this

6 approach, we assumed complete absorption of alpha-particle energies for all tissues except those associated

7 with the skeleton. To calculate alpha-particle absorbed dose for skeletal regions (i.e., the red marrow and

8 trabecular bone surface), we used alpha-particle absorbed fractions published by Watchman, et al. [13]).

9 Monte Carlo calculations performed by Watchman, et al. using marrow trabecular geometry that is directly

10 measured from cadavers have shown that the factor of 0.5 is an overestimate for the alpha energies emitted

11 by thorium-227 and by radium-223 and its daughters. Furthermore, in the latest ICRP skeletal bone

12 geometry, the osteogenic bone surface has been replaced by a 50- $\mu \mathrm{m}$ thick layer of endosteal cells, referred

13 to as the trabecular bone endosteum.

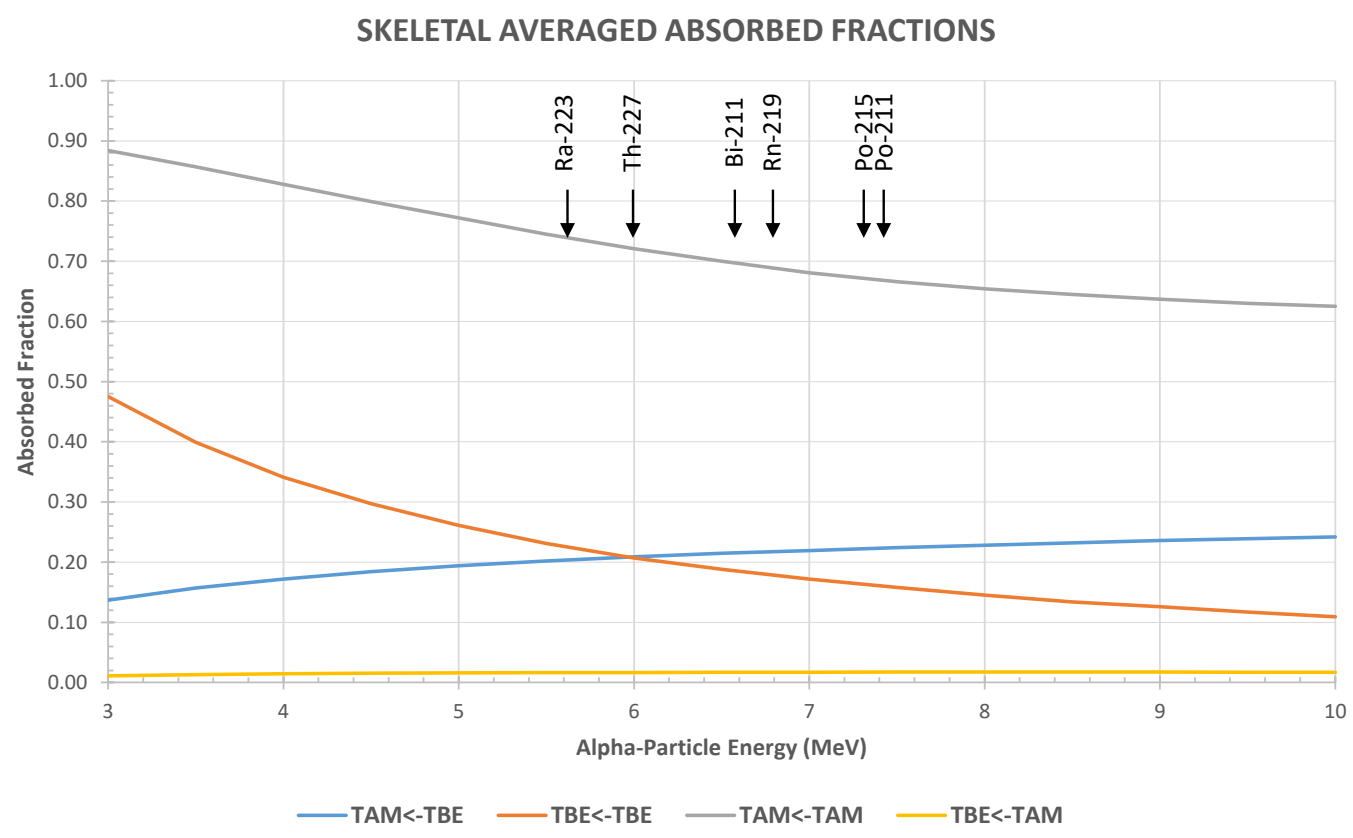

15 Figure 12: Absorbed fraction vs alpha-particle energy. The figure shows that the self-dose absorbed fractions 16 (TAM $\leftarrow$ TAM) are less than 1 and the cross dose absorbed fractions (TAM $\leftarrow$ TBE) are less than 0.5 The 
1 energy of alpha particles (with a yield greater than 20\%) and corresponding alpha emitters is shown by

2 arrows. TAM <- Trabecular Active Marrow, TBE <- Trabecular Bone Endosteum.

3 The energies of the alpha particles emitted by thorium-227 and its daughters are between 5.5 and $7.5 \mathrm{MeV}$.

4 As demonstrated by the arrows in Figure 12, the corresponding skeletal average absorbed fraction for 5 decays originating in the trabecular bone surface (previously referred to as the trabecular bone endosteum 6 (TBE)) irradiating the trabecular active marrow (TAM) range from 0.20 to 0.22 .

7 The data set used for the absorbed dose comparisons was for a therapeutic alpha-particle emitting 8 radionuclide (Figure 6 and Table 3) with measurements obtained from counting of extracted pre-clinical 9 tissues. Pre-clinical tissue TIAC values were provided as input for the calculations (Table 4). This required 10 conversion of TIAC from pre-clinical to human (Eq. 1).

11 Table 7 lists the TIACs assigned to different source tissues according to the calculation method employed.

12 The values in the table reflect a number of decisions made across the different methods. The first 13 observation is that the TIAC assigned to the same tissue differs across the different methods. For example, 14 the TIAC for thorium-227 in the adrenals was $0.21 \mathrm{~h}$ for the CEP/Hybrid method but was $0.226 \mathrm{~h}$ for the 15 ICRP method. This is because the translation of pre-clinical TIAC to human TIAC used ICRP phantom 16 organ and whole-body masses (Eqn. 1) instead of the CE/OLINDA phantom masses. Table 4 lists the pre17 clinical TIAC concentrations for gall bladder and large intestine. The gall bladder, upper and lower large 18 intestine walls are not source tissues in the CEP. To calculate the electron and photon dose contributions, 19 TIACs for these tissues were treated as sources in the respective contents of each organ. For the large 20 intestine, the TIAC was apportioned to human equivalent upper and lower large intestine contents based on

21 the fractional mass of the walls. In the hybrid calculations, we placed the TIAC into the wall assuming 22 complete absorption of alpha-particle energy in the wall using the mass of the wall listed for the CE phantom 23 (Table 1 of the Appendix). The ICRP phantom provides both the wall and contents as source regions; we 24 placed the TIAC in the wall: since the measurements came from direct sampling, we assumed that the wall 25 was counted and not the contents. As indicated in Error! Reference source not found., the digestive tract 
1 anatomy is redefined in the ICRP phantoms: the upper and lower large intestines have been replaced by the

2 right and left colon and the rectosigmoid colon. Accordingly, the TIACs used for these tissues in the ICRP

3 phantom were apportioned as shown in Table 2.

4 Table 7 shows that the ICRP phantom includes tissues not available in the CEP. The data set used in this

5 work included TIAC values for the mesenteric lymph nodes and prostate. These were assigned to the extra

6 thoracic lymph nodes and prostate, respectively. The source tissues in the ICRP phantom are indicated in

7 Table 2 of the Appendix.

8 To understand the impact of adopting ICRP-phantom-derived S-values, the individual absorbed dose

9 contribution for each emission type to the total absorbed dose is listed for each of the three methods (Table

10 8-10 and Figure 7-10). Since both thorium-227 and radium-223 emit alpha-particles, the total absorbed dose

11 across all daughter emissions (Table 11 and Figure 10) is dominated by the dose contribution arising from

12 alpha-particles.

13 In Table 8-10, differences in target nomenclature are indicated. For example, "Lungs" in the CEP phantom

14 corresponds to "AI" in the ICRP phantom notation (Figure 3). Likewise, "osteogenic cells" correspond to

15 "endosteum-bs" (Figure 5). The endosteum-bs region is defined as a 580 (male) or $430 \mathrm{~g}$ (female), $50 \mu \mathrm{m}$ -

16 thick layer of endosteal cells at the surface of trabecular bone. GI tissue walls have been replaced by stem

17 cell layers in the ICRP model. The small intestine, which was not separated into contents and wall regions

18 in the CEP, has been so separated in ICRP phantom (Error! Reference source not found.). In addition,

19 the extrathoracic lymph nodes (ln-et), prostate and rectosigmoid wall (rs-stem) are ICRP target regions not

20 available in the CEP data.

21 The percent difference in absorbed dose for photon, electron and alpha-particle emissions arising from

22 thorium-227 are listed on Table 12. The hybrid methodology used CEP estimates as calculated by OLINDA

23 so that the photon end electron dose values are identical. As noted earlier, the hybrid method assumed

24 complete alpha-particle absorption except for skeletal tissues. Accordingly, hybrid dose values for alpha

25 particles differ from those obtained using OLINDA. 
1 Table 12: Percent difference* in thorium-227 absorbed dose (w/o daughter contributions) relative to the ICRP 2 method.

\begin{tabular}{|l|c|c|c|c|}
\hline & \multicolumn{2}{|c|}{ CEP/Hybrid } & CEP & Hybrid \\
\hline Target Tissue $^{1}$ & Photon & Electron & Alpha & Alpha \\
\hline adrenals & 62.6 & 62.8 & -0.1 & 0.0 \\
\hline lungs (CEP, hybrid)/Alveolar-Interstitial (ICRP) & 55.5 & 64.4 & 3.2 & 3.6 \\
\hline Brain & 35.1 & 63.3 & -0.3 & 0.0 \\
\hline osteogenic cells (CEP, hybrid)/endost-bs (ICRP) & 76.2 & -22.0 & -402.1 & -84.7 \\
\hline gb-wall & 68.8 & 95.4 & 86.4 & -43.9 \\
\hline ht-wall & 54.6 & 62.1 & -0.3 & -0.4 \\
\hline kidneys & 52.2 & 62.3 & -0.3 & -0.3 \\
\hline ULI wall (CEP, hybrid)/ lc-stem (ICRP) & 17.4 & n/a & n/a & n/a \\
\hline liver & 32.0 & 62.3 & -0.2 & -0.1 \\
\hline ln-et & n/a & n/a & n/a & n/a \\
\hline muscle & 10.7 & 63.2 & -0.3 & -0.1 \\
\hline pancreas & 66.6 & 62.7 & -0.3 & -0.1 \\
\hline prostate & n/a & n/a & n/a & n/a \\
\hline r-marrow & 58.6 & 50.9 & -212.8 & -37.9 \\
\hline LLI-wall (CEP, hybrid)/rc-stem (ICRP) & 92.4 & n/a & n/a & n/a \\
\hline rs-stem & n/a & n/a & n/a & n/a \\
\hline si-wall (hybrid)/si-stem (ICRP) & 50.8 & n/a & n/a & n/a \\
\hline spleen & 48.7 & 62.3 & -0.3 & 0.0 \\
\hline thyroid & 73.1 & 62.1 & -0.2 & 0.1 \\
\hline 1Refer to Appendix 1 (Table 3) for full form of target region acronyms used in the table & \\
\hline *(ICRP absorbed dose-CEP or hybrid absorbed dose)/ICRP absorbed dose & & \\
\hline
\end{tabular}

4 In the ICRP method, photon absorbed dose for every tissue listed is greater than that calculated using the

5 CEP method. This is most likely a combination of greater accuracy in the absorbed fraction calculations

6 due to substantially more powerful computing capabilities and also anatomical differences in the phantoms

7 (Figure 11). The former probably better accounts for absorption of low energy photons, while the latter

8 provides a contiguous anatomy with no gaps between organs. Another possible source of differences could

9 be due to differences in the decay spectrum used for thorium-227. 
1 The significant differences in electron absorbed doses are somewhat surprising. Except for osteogenic cells/

2 endosteum bone surface, they are not attributable to differences in TIAC values (Table 7) or phantom organ

3 masses (Tables 1-3, in the Appendix). For most tissues, the ICRP dose estimates approximate the estimate

4 provided by complete absorption of electron energy. For example, the electron absorbed dose for liver

5 assuming complete electron energy absorption is $7.69 \mathrm{mGy} / \mathrm{MBq}$ while the ICRP calculated absorbed dose

6 is $7.68 \mathrm{mGy} / \mathrm{MBq}$. Since electron absorbed fractions for CEP were estimated assuming complete absorption

7 for self-dose and zero for cross-organ doses, the substantial differences are likely due to differences in the

8 electron spectrum used for the electron absorbed dose calculations. Interestingly, there is much better

9 agreement in the electron dose between the OLINDA implementation of CEP and that obtained using ICRP

10 for ${ }^{177} \mathrm{Lu}$ (data not shown). Lutetium-177 is primarily a beta-particle emitter; the beta-particle energy

11 emitted per disintegration of ${ }^{177} \mathrm{Lu}$ is almost 3 orders of magnitude greater than that for monoenergetic

12 (Auger, conversion) electrons. Thorium-227 does not emit beta-particles, and the monoenergetic electron

13 energy emitted is predominantly due to emissions below $1 \mathrm{MeV}$. Accordingly, the difference in electron

14 absorbed doses may be due to differential handling of low energy emissions in the Monte Carlo simulations

15 or possibly a decay scheme that abridges the monoenergetic electrons for thorium-227 used in the absorbed

16 fraction calculations in the OLINDA implementation of the CEP phantoms.

17 In evaluating the differences in alpha-particle absorbed dose, we confined the discussion to the Hybrid

18 calculation where the methodology and input data used to arrive at the dose estimates are well described.

19 The percent differences between the hybrid and ICRP results for alpha particle absorbed dose are far less

20 for most organs than that observed for photon and electron absorbed doses. Since the absorbed dose from

21 thorium-227 is dominated by its alpha-particle emissions, the discrepancy in photon and electron absorbed

22 doses is practically inconsequential. The brain, osteogenic cells, gallbladder wall and red marrow show

23 differences greater than 5\%. These are due to a combination of differences in tissue mass/tissue definition

24 and the TIAC assigned for the CEP/hybrid combination compared to the ICRP values. The very small 
1 percent differences in other tissues are likely due to rounding errors associated with mass and total alpha-

2 particle energy used in the calculations

3 The discrepancy between alpha absorbed dose for the gall bladder wall arises because complete absorption

4 of alpha-particle energy was assumed in the hybrid calculations but not the ICRP calculations. For example,

5 the results suggest that approximately $40 \%$ of the alpha-particle emissions arising from decays in the gall

6 bladder wall deposit energy outside the wall. The large percent differences in absorbed dose for osteogenic

7 cells and for the red marrow are examined in Table 13. As indicated in the methods section, the RM and

8 osteogenic cell absorbed doses using the hybrid method were calculated using cross-tissue specific absorbed

9 fractions to calculate the S-values shown in Table 6. Table 13 lists the results of each method and also the

10 corresponding value for complete absorption. Adjusting for differences due to mass and TIAC for the ICRP

11 (top portion of table) versus hybrid method (bottom portion of table), as per equation 14, gives an ICRP-

12 equivalent marrow self-absorbed dose that is $1.88 \mathrm{E}-03 \mathrm{mGy} / \mathrm{kBq}$. This is $21 \%$ greater than the actual ICRP

13 marrow self-absorbed dose, calculated using ICRP-derived S-values and corresponds to the difference in

14 the RM-to-RM absorbed fraction obtained using the ICRP vs hybrid methods. Applying this same

15 calculation for the endosteal (or osteogenic cell) target, the ICRP-equivalent absorbed dose to bone

16 endosteum is $4.60 \mathrm{E}-02 \mathrm{mGy} / \mathrm{kBq}$, a $57 \%$ difference. Since the alpha-particle energy spectrum used in both

17 calculations is the same, these differences are probably due to a combination of differences due to tissue

18 geometry and Monte Carlo techniques. Comparing these self-dose \% differences with those listed on Table

1912 suggests that the values in Table 12 for these tissues are dominated by differences in the self-absorbed

20 dose.

$21 \quad \mathrm{D}_{\mathrm{ICRP}}\left(\mathrm{r}_{\mathrm{T}}\right)=\mathrm{D}_{\text {hybrid }}\left(\mathrm{r}_{\mathrm{T}}\right) \cdot\left(\frac{\operatorname{TIAC}_{\mathrm{ICRP}}\left(\mathrm{r}_{\mathrm{T}}\right)}{\operatorname{TIAC}_{\text {hybrid }}\left(\mathrm{r}_{\mathrm{T}}\right)}\right) \cdot\left(\frac{\mathrm{M}_{\text {hybrid }}\left(\mathrm{r}_{\mathrm{T}}\right)}{\mathrm{M}_{\mathrm{ICRP}}\left(\mathrm{r}_{\mathrm{T}}\right)}\right)$ 
Table 13: Alpha particle absorbed dose components for skeletal tissues (mGy/kBq)

\begin{tabular}{|c|c|c|c|c|}
\hline \multirow{3}{*}{ Source tissue (TIAC) } & \multicolumn{4}{|c|}{ Target tissue $\left(r_{T}\right)$} \\
\hline & \multicolumn{2}{|c|}{$\begin{array}{c}\text { RM } \\
(1.39 \mathrm{~kg})\end{array}$} & \multicolumn{2}{|c|}{$\begin{array}{c}\text { Endosteal cells } \\
(0.580 \mathrm{~kg})\end{array}$} \\
\hline & ICRP & $\varphi=1$ & ICRP & $\varphi=1$ \\
\hline $\mathrm{RM}(1.06 \mathrm{~h})$ & $1.56 \mathrm{E}-03$ & $2.59 \mathrm{E}-03$ & $7.04 \mathrm{E}-04$ & $\mathrm{n} / \mathrm{a}$ \\
\hline Endosteal-bs $(37.0 \mathrm{~h})$ & $1.47 \mathrm{E}-02$ & $\mathrm{n} / \mathrm{a}$ & $1.07 \mathrm{E}-01$ & $2.16 \mathrm{E}-01$ \\
\hline \multirow[t]{3}{*}{ Total absorbed dose } & $1.62 \mathrm{E}-02$ & $\mathrm{n} / \mathrm{a}$ & $6.88 \mathrm{E}-01$ & $\mathrm{n} / \mathrm{a}$ \\
\hline & \multicolumn{2}{|c|}{$\begin{array}{c}\text { RM } \\
(1.09 \mathrm{~kg})\end{array}$} & \multicolumn{2}{|c|}{$\begin{array}{c}\text { Osteogenic cells } \\
\quad(0.108 \mathrm{~kg})\end{array}$} \\
\hline & hybrid & $\varphi=1$ & hybrid & $\varphi=1$ \\
\hline $\mathrm{RM}(0.85 \mathrm{~h})$ & $1.92 \mathrm{E}-03$ & $2.65 \mathrm{E}-03$ & 4.43E-04 & $\mathrm{n} / \mathrm{a}$ \\
\hline Endosteal-bs (31.7 h) & $2.05 \mathrm{E}-02$ & $\mathrm{n} / \mathrm{a}$ & $2.11 \mathrm{E}-01$ & $9.95 \mathrm{E}-01$ \\
\hline Total absorbed dose & $2.24 \mathrm{E}-02$ & $\mathrm{n} / \mathrm{a}$ & $2.12 \mathrm{E}-01$ & $\mathrm{n} / \mathrm{a}$ \\
\hline
\end{tabular}

$\varphi-$ absorbed fraction

\section{CONCLUSIONS}

4 Absorbed fractions based on much more realistic phantoms were published by the ICRP in 2016. Despite

5 the substantial improvements in both anatomy and calculational techniques that enabled more accurate transport of photons and also enabled transport of electrons and alpha particles, the ICRP data have not been widely adopted for dosimetry calculations in RPT. In this work, we describe a pathway for making the transition from CEP-based to ICRP-based dosimetry. Our comparisons suggest substantial differences

9 between CEP-based results for photon and electron emissions of the alpha-emitter thorium-227. Given that

10 the ICRP phantoms better represent human anatomy and that the resulting absorbed fractions better account

11 for photon, electron and alpha-particle transport, the results suggest that it is imperative for the field to 12 adopt ICRP-based phantom and corresponding absorbed fractions for RPT dosimetry.

\section{DECLARATIONS}

14 Ethics approval and consent to participate: Not Applicable 
Consent for publication: Not Applicable

2 Availability of data and material: Not Applicable

3 Competing interests:

4 GS: Under a license agreement between Rapid and the Johns Hopkins University, the University and Dr.

5 Sgouros are entitled to royalty distributions related to technology described in the study discussed in this

6 [publication/presentation]. Dr. Sgouros is a founder of and holds equity in Radiopharmaceutical Imaging

7 and Dosimetry, LLC (Rapid). And he serves as a member of Rapid's Board of Directors. This

8 arrangement has been reviewed and approved by the Johns Hopkins University in accordance with its

9 conflict-of-interest policies

10 EF is a founder of and holds equity in Radiopharmaceutical Imaging and Dosimetry, LLC (Rapid). He

11 also serves as a member of Rapid's Board of Directors.

$12 \mathrm{HH}$ is an employee and shareholder of Bayer AG.

$13 \mathrm{SJ}$ is an employee of Bayer AG.

$14 \mathrm{TP}$ is an employee and shareholder of Bayer AG.

$15 \mathrm{AC}$ is an employee and shareholder of Bayer AG.

16 All other authors declare that they have no competing interests.

17 Funding and Acknowledgements: The work described in this paper is funded by SBIR grant 1 R43

18 CA224643-01A1

19 Authors' contributions: GS, BH, EF, SS conceived this research, performed the calculations,

20 participated in the analysis and discussion. TP, HH, AP and SJ were responsible for data collection. WB

21 and DJ have helped develop the ICRP phantoms over the years and also participated in the analysis and

22 discussion. Their insight helped understanding and establishing the correspondence between the two

23 phantom models. All authors read, reviewed and approved the final manuscript. 


\section{REFRENCES}

2 1. Snyder, W.S., M.R. Ford, and G.G. Warner, MIRD pamphlet no. 5, revised: Estimates of specific 3 absorbed fractions for photon sources uniformly distributed in various organs of a heterogeneous $4 \quad$ phantom. New York, NY: Society of Nuclear Medicine, 1978.

$5 \quad 2 . \quad$ Snyder, W.S., et al., "S" absorbed dose per unit cumulated activity for selected radionuclides and 6 organs. MIRD Pamphlet No. 11. 1975, New York: Society of Nuclear Medicine.

7 3. Loevinger, R. and M. Berman, A schema for calculating the absorbed dose from biologically 8 distributed radionuclides. MIRD Pamphlet No. 1. J Nucl Med, 1968. 9(Supp 1): p. 5.

9 4. Bolch, W.E., et al., MIRD pamphlet No. 21: a generalized schema for radiopharmaceutical 10 dosimetry--standardization of nomenclature. J Nucl Med, 2009. 50(3): p. 477-84.

$115 . \quad$ Hines, G. and G. Brownell, Radiation Dosimetry. 1956, New York: Academic Press.

12 6. Cristy, M. and K.F. Eckerman, Specific absorbed fractions of energy at various ages from 13 internal photon sources. 1987, Oak Ridge National Laboratory: Oak Ridge, TN.

$147 . \quad$ Cristy, M., Mathematical phantoms representing children of various ages for use in estimates of 15 internal dose. 1980, Oak Ridge National Laboratory: Oak Ridge, Tennessee.

16 8. Stabin, M.G., R.B. Sparks, and E. Crowe, OLINDA/EXM: the second-generation personal 17 computer software for internal dose assessment in nuclear medicine. J Nucl Med, 2005. 46(6): p. $18 \quad 1023-7$.

19 9. Bolch, W.E., et al., ICRP Publication 133: The ICRP computational framework for internal dose assessment for reference adults: specific absorbed fractions. Annals of the ICRP, 2016. 45(2): p.

22 10. ICRP, Publication 89, Basic anatomical and physiological data for use in radiological protection - reference values. Ann ICRP, 2002. 32(3-4): p. 1-277.

24 11. International Commission on Radiological, P., Human alimentary tract model for radiological 25 protection. ICRP Publication 100. Ann. ICRP, 2006. 36(1-2). 
1 12. Eckerman, K. and A. Endo, ICRP Publication 107. Nuclear decay data for dosimetric calculations. Annals of the ICRP, 2007. 38(3): p. 7-96.

3 13. Watchman, C.J., et al., Absorbed fractions for alpha-particles in tissues of trabecular bone:

$4 \quad$ Considerations of marrow cellularity within the ICRP reference male. J Nucl Med, 2005. 46(7):

$5 \quad$ p. $1171-1185$.

6 14. ICRP, Publication 70, Basic Anatomical and Physiological Data for Use in Radiological

7 Protection: The Skeleton. ICRP Publication 70. 1995, Oxford UK: International Commission on $8 \quad$ Radiological Protection.

9 15. Eckerman, K.F. and A. Enzo, MIRD: Radionuclide data and decay schemes, 2nd Edition. 2008, 10 Reston, VA: Society of Nuclear Medicine.

11 16. Azure, M.T., et al., Biological effect of lead-212 localized in the nucleus of mammalian cells: role 12 of recoil energy in the radiotoxicity of internal alpha-particle emitters. Radiat Res, 1994. 140(2): 13 p. $276-83$.

14 17. Fritsch, F.N. and R.E. Carlson, MONOTONE PIECEWISE CUBIC INTERPOLATION. Siam $15 \quad$ Journal on Numerical Analysis, 1980. 17(2): p. 238-246.

16 18. Menzel, H.G., C. Clement, and P. DeLuca, ICRP Publication 110. Realistic reference phantoms: 17 an ICRP/ICRU joint effort. A report of adult reference computational phantoms, in Ann ICRP. 18 2009: England. p. 1-164.

19 19. Liu, H.K., et al., Comparison of two types of adult phantoms in terms of organ doses from 20 diagnostic CT procedures. Physics in Medicine and Biology, 2010. 55(5): p. 1441-1451.

21 20. Wayson MB, Leggett RW, Jokisch DW, Lee C, Schwarz BC, Godwin WJ, Bolch WE. Suggested reference values for regional blood volumes in children and adolescents. Phys Med Biol. 2018 Aug 6;63(15):155022. doi: 10.1088/1361-6560/aad313. PMID: 29999494; PMCID: PMC6343858.

24 21. Kim, C.H., (in press). ICRP, Publication 145, Adult Mesh-type Reference Computational 25 Phantoms. http://www.icrp.org/page.asp?id=395 
2 Table 1: Source and Target tissue masses described in OLINDA and CEP for Reference Adult Male

3 Phantom

Reference Adult Male Phantom Organ Masses (kg)

\begin{tabular}{|c|c|c|}
\hline Source and Target Regions ${ }^{1}$ & $\begin{array}{c}\text { Masses listed in } \\
\text { OLINDA software }\end{array}$ & $\begin{array}{l}\text { CE Phantom } \\
\text { Paper }\end{array}$ \\
\hline Adrenals & $1.63 \mathrm{E}-02$ & $1.63 \mathrm{E}-02$ \\
\hline Bone, cort & $4.00 \mathrm{E}+00$ & $4.00 \mathrm{E}+00$ \\
\hline Bone, trab & $1.00 \mathrm{E}+00$ & $1.00 \mathrm{E}+00$ \\
\hline Brain & $1.42 \mathrm{E}+00$ & $1.42 \mathrm{E}+00$ \\
\hline Breasts & $3.51 \mathrm{E}-01$ & $3.51 \mathrm{E}-01$ \\
\hline Gallbladder Wall & $1.05 \mathrm{E}-02$ & $1.05 \mathrm{E}-02$ \\
\hline Gall Bladder contents & $\mathrm{n} / \mathrm{a}$ & $5.57 \mathrm{E}-02$ \\
\hline LLI Wall & $1.67 \mathrm{E}-01$ & $1.67 \mathrm{E}-01$ \\
\hline LLI Contents & $\mathrm{n} / \mathrm{a}$ & $1.43 \mathrm{E}-01$ \\
\hline ULI walls & $2.20 \mathrm{E}-01$ & $2.20 \mathrm{E}-01$ \\
\hline ULI contents & $\mathrm{n} / \mathrm{a}$ & $2.32 \mathrm{E}-01$ \\
\hline Small Intestine & $6.77 \mathrm{E}-01$ & $1.10 \mathrm{E}+00$ \\
\hline Stomach Wall & $1.58 \mathrm{E}-01$ & $1.53 \mathrm{E}-01$ \\
\hline Stomach contents & $\mathrm{n} / \mathrm{a}$ & $2.60 \mathrm{E}-01$ \\
\hline Heart Contents & $\mathrm{n} / \mathrm{a}$ & $4.54 \mathrm{E}-01$ \\
\hline Heart Wall & $3.16 \mathrm{E}-01$ & $3.16 \mathrm{E}-01$ \\
\hline Kidneys & 2.99E-01 & 2.99E-01 \\
\hline Liver & $1.91 \mathrm{E}+00$ & $1.91 \mathrm{E}+00$ \\
\hline Lungs & $1.00 \mathrm{E}+00$ & $1.00 \mathrm{E}+00$ \\
\hline Muscle & $2.80 \mathrm{E}+01$ & $5.18 \mathrm{E}+01$ \\
\hline Osteogenic cells & $1.20 \mathrm{E}-01$ & $1.08 \mathrm{E}-01 *$ \\
\hline Ovaries & $0.00 \mathrm{E}+00$ & $0.00 \mathrm{E}+00$ \\
\hline Pancreas & $9.43 \mathrm{E}-02$ & $9.43 \mathrm{E}-02$ \\
\hline Red Marrow & $1.12 \mathrm{E}+00$ & $1.12 \mathrm{E}+00$ \\
\hline Spleen & $1.83 \mathrm{E}-01$ & $1.83 \mathrm{E}-01$ \\
\hline Testes & $3.91 \mathrm{E}-02$ & $3.91 \mathrm{E}-02$ \\
\hline
\end{tabular}




\begin{tabular}{lcc}
\hline Thymus & $2.00 \mathrm{E}-02$ & $2.09 \mathrm{E}-02$ \\
\hline Thyroid & $2.07 \mathrm{E}-02$ & $2.07 \mathrm{E}-02$ \\
\hline Urinary Bladder Wall & $4.76 \mathrm{E}-02$ & $4.76 \mathrm{E}-02$ \\
\hline Urinary Bladder Contents & $\mathrm{n} / \mathrm{a}$ & $2.11 \mathrm{E}-01$ \\
\hline Uterus/Uterine Wall & $0.00 \mathrm{E}+00$ & $0.00 \mathrm{E}+00$
\end{tabular}

$1 \%$ CEP does not list endosteal cell mass, the value listed was obtained from reference [13] and was used to

2 calculate skeletal S-values as described in the methods. This value was also used to convert pre-clinical to 3 human TIAC in Eqn. 1

4 Table 2: ICRP 110 Adult Male and Female Reference phantom Source tissue masses*

\begin{tabular}{|c|c|c|c|}
\hline Source Region & $\begin{array}{r}\text { ICRP } 110 \text { Ref } \\
\text { Adult Male } \\
\text { Tissue Mass } \\
(\mathrm{kg})\end{array}$ & $\begin{array}{r}\text { ICRP } 110 \text { Ref Adult } \\
\text { Female Tissue Mass } \\
(\mathrm{kg})\end{array}$ & Acronym \\
\hline Adipose & $1.751 \mathrm{E}+01$ & $2.176 \mathrm{E}+01$ & Adipose \\
\hline Adrenals & $1.736 E-02$ & $1.546 E-02$ & Adrenals \\
\hline Alveolar-intersitial & $1.100 \mathrm{E}+00$ & $9.000 \mathrm{E}-01$ & $\mathrm{AI}$ \\
\hline Blood & $5.600 \mathrm{E}+00$ & $4.100 \mathrm{E}+00$ & Blood \\
\hline Brain & $1.517 E+00$ & $1.349 E+00$ & Brain \\
\hline Bronchiolar surface & $0.000 \mathrm{E}+00$ & $0.000 \mathrm{E}+00$ & Brchiole \\
\hline Bronchiolar bound region & $4.891 \mathrm{E}-03$ & $4.703 \mathrm{E}-03$ & Brchiole-b \\
\hline Bronchiolar sequestered region & $1.252 \mathrm{E}-03$ & $1.204 \mathrm{E}-03$ & Brchiole-q \\
\hline Breast & $2.617 E-02$ & $5.154 E-01$ & Breast \\
\hline Bronchial surface & $0.000 \mathrm{E}+00$ & $0.000 \mathrm{E}+00$ & Bronchi \\
\hline Bronchial bound region & $1.727 \mathrm{E}-03$ & $1.552 \mathrm{E}-03$ & Bronchi-b \\
\hline Bronchial sequestered region & $2.918 \mathrm{E}-04$ & $2.622 \mathrm{E}-04$ & Bronchi-q \\
\hline Cartilage & $1.156 \mathrm{E}+00$ & $9.410 \mathrm{E}-01$ & Cartilage \\
\hline Cortical bone surfaces & $0.000 \mathrm{E}+00$ & $0.000 \mathrm{E}+00$ & C-bone-S \\
\hline Cortical bone volumes & $4.445 \mathrm{E}+00$ & $3.233 \mathrm{E}+00$ & C-bone-V \\
\hline Cortical marrow & $2.790 \mathrm{E}-01$ & $2.580 \mathrm{E}-01$ & C-marrow \\
\hline ET1 surface & $0.000 \mathrm{E}+00$ & $0.000 \mathrm{E}+00$ & ET1-sur \\
\hline ET1 wall & $3.991 \mathrm{E}-03$ & $2.778 \mathrm{E}-03$ & ET1-wall \\
\hline ET2 bound region & $2.472 \mathrm{E}-03$ & $2.137 \mathrm{E}-03$ & ET2-bnd \\
\hline
\end{tabular}




\begin{tabular}{|c|c|c|c|}
\hline ET2 sequestered region & $4.504 \mathrm{E}-04$ & 3.894E-04 & ET2-seq \\
\hline ET2 surface & $0.000 \mathrm{E}+00$ & $0.000 \mathrm{E}+00$ & ET2-sur \\
\hline ET2 wall & $3.991 \mathrm{E}-03$ & $2.778 \mathrm{E}-03$ & ET2-wall \\
\hline Eye Lens & $4.000 \mathrm{E}-04$ & $4.000 \mathrm{E}-04$ & Eye-lens \\
\hline Gall bladder content & $5.800 E-02$ & $4.800 E-02$ & GB-cont \\
\hline Gall bladder wall & $1.047 \mathrm{E}-02$ & $8.246 \mathrm{E}-03$ & GB-wall \\
\hline Heart wall & $3.860 \mathrm{E}-01$ & $2.910 \mathrm{E}-01$ & Ht-wall \\
\hline Kidneys & $4.220 E-01$ & $3.570 E-01$ & Kidneys \\
\hline Left colon content & $7.500 \mathrm{E}-02$ & $8.000 \mathrm{E}-02$ & LC-cont \\
\hline Left colon mucosa & $1.875 \mathrm{E}-02$ & $1.726 \mathrm{E}-02$ & LC-mucosa \\
\hline Left colon wall & $1.862 \mathrm{E}-01$ & $1.714 \mathrm{E}-01$ & LC-wall \\
\hline Liver & $2.360 E+00$ & $1.810 E+00$ & Liver \\
\hline Lymph Nodes - Extrathoracic & $1.595 \mathrm{E}-02$ & $1.270 \mathrm{E}-02$ & LN-ET \\
\hline Lymph Nodes - Systemic & $1.577 \mathrm{E}-01$ & $1.255 \mathrm{E}-01$ & LN-Sys \\
\hline Lymph Nodes - Thoracic & $1.595 \mathrm{E}-02$ & $1.270 \mathrm{E}-02$ & LN-Th \\
\hline Lungs (with blood) & $1.200 \mathrm{E}+00$ & $9.500 \mathrm{E}-01$ & Lungs \\
\hline Lung Tissue & $1.200 E+00$ & $9.500 E-01$ & Lung-Tis \\
\hline Muscle & $2.978 \mathrm{E}+01$ & $1.793 \mathrm{E}+01$ & Muscle \\
\hline Oral cavity & $0.000 \mathrm{E}+00$ & $0.000 \mathrm{E}+00$ & O-cavity \\
\hline Oesophagus - fast & $0.000 \mathrm{E}+00$ & $0.000 \mathrm{E}+00$ & Oesophag-f \\
\hline Oesophagus - slow & $0.000 \mathrm{E}+00$ & $0.000 \mathrm{E}+00$ & Oesophag-s \\
\hline Oesophagus wall & 4.904E-02 & $4.129 \mathrm{E}-02$ & Oesophag-w \\
\hline Oral mucosa & $3.583 \mathrm{E}-02$ & $2.245 \mathrm{E}-02$ & O-mucosa \\
\hline Ovaries & $0.000 E+00$ & $1.264 E-02$ & Ovaries \\
\hline Pancreas & $1.736 E-01$ & $1.446 E-01$ & Pancreas \\
\hline Pituitary gland & $6.280 \mathrm{E}-04$ & $6.180 \mathrm{E}-04$ & P-gland \\
\hline Prostate & $1.780 \mathrm{E}-02$ & $0.000 \mathrm{E}+00$ & Prostate \\
\hline Right colon content & $1.500 \mathrm{E}-01$ & $1.600 \mathrm{E}-01$ & RC-cont \\
\hline Right colon mucosa & $2.010 \mathrm{E}-02$ & $1.773 \mathrm{E}-02$ & RC-mucosa \\
\hline Right colon wall & $1.862 \mathrm{E}-01$ & $1.714 \mathrm{E}-01$ & RC-wall \\
\hline Red marrow & $1.394 E+00$ & $1.064 E+00$ & $R$-marrow \\
\hline Rectosigmoid colon content & $7.500 \mathrm{E}-02$ & $8.000 \mathrm{E}-02$ & RS-cont \\
\hline Rectosigmoid colon mucosa & $1.128 \mathrm{E}-02$ & $1.039 \mathrm{E}-02$ & RS-mucosa \\
\hline Rectosigmoid colon wall & $8.691 \mathrm{E}-02$ & $8.273 \mathrm{E}-02$ & RS-wall \\
\hline
\end{tabular}




\begin{tabular}{|c|c|c|c|}
\hline Respiratory tract air & $0.000 \mathrm{E}+00$ & $0.000 \mathrm{E}+00$ & RT-air \\
\hline Salivary glands & $8.898 \mathrm{E}-02$ & $7.215 \mathrm{E}-02$ & S-glands \\
\hline Small Intestine content & $3.500 \mathrm{E}-01$ & $2.800 \mathrm{E}-01$ & SI-cont \\
\hline Small Intestine mucosa & $3.696 \mathrm{E}-02$ & $3.432 \mathrm{E}-02$ & SI-mucosa \\
\hline Small Intestine villi & $1.252 \mathrm{E}-02$ & $1.252 \mathrm{E}-02$ & SI-villi \\
\hline Small Intestine wall & $8.088 \mathrm{E}-01$ & 7.163E-01 & SI-wall \\
\hline Skin & $3.468 E+00$ & $2.423 E+00$ & Skin \\
\hline Spleen & $2.284 E-01$ & $1.874 E-01$ & Spleen \\
\hline Stomach content & $2.500 E-01$ & $2.300 E-01$ & St-cont \\
\hline Stomach mucosa & $4.639 \mathrm{E}-03$ & $4.639 \mathrm{E}-03$ & St-mucosa \\
\hline Stomach wall & $1.839 \mathrm{E}-01$ & $1.652 \mathrm{E}-01$ & St-wall \\
\hline Trabecular bone surfaces & $0.000 \mathrm{E}+00$ & $0.000 \mathrm{E}+00$ & T-bone-S \\
\hline Trabecular bone volumes & $1.167 E+00$ & $8.492 E-01$ & T-bone-V \\
\hline Teeth surfaces & $0.000 \mathrm{E}+00$ & $0.000 \mathrm{E}+00$ & Teeth-S \\
\hline Teeth volumes & $5.000 \mathrm{E}-02$ & $4.000 \mathrm{E}-02$ & Teeth-V \\
\hline Testes & $3.724 E-02$ & $0.000 E+00$ & Testes \\
\hline Thymus & $2.617 E-02$ & $2.062 E-02$ & Thymus \\
\hline Thyroid & $2.336 E-02$ & $1.946 E-02$ & Thyroid \\
\hline Trabecular marrow & $3.371 \mathrm{E}+00$ & $2.442 \mathrm{E}+00$ & T-marrow \\
\hline Tongue & 7.642E-02 & $6.185 \mathrm{E}-02$ & Tongue \\
\hline Tonsils & $3.141 \mathrm{E}-03$ & $3.092 \mathrm{E}-03$ & Tonsils \\
\hline Urinary bladder content & $2.000 E-01$ & $2.000 E-01$ & UB-cont \\
\hline Urinary bladder wall & $5.112 \mathrm{E}-02$ & $4.082 \mathrm{E}-02$ & UB-wall \\
\hline Ureters & $1.675 \mathrm{E}-02$ & $1.546 \mathrm{E}-02$ & Ureters \\
\hline Uterus & $0.000 E+00$ & $8.246 E-02$ & Uterus \\
\hline Yellow marrow & $2.480 \mathrm{E}+00$ & $1.800 \mathrm{E}+00$ & Y-marrow \\
\hline Totals (all listed tissues): & 73.3064824 & 60.1019016 & \\
\hline
\end{tabular}

1 *Italicized rows correspond to source regions listed in CEP/OLINDA compilation

2 Table 3: Target Tissue Regions and their masses (kgs) as given in ICRP 133*

\section{Masses Inclusive of Blood (kg)}

\begin{tabular}{lrrr} 
Target Region & Adult Male & Adult Female & Acronym \\
\hline Oral Mucosa & $3.58 \mathrm{E}-02$ & $2.25 \mathrm{E}-02$ & O-mucosa \\
\hline
\end{tabular}




\begin{tabular}{|c|c|c|c|}
\hline Oesophagus & $9.50 \mathrm{E}-05$ & $8.80 \mathrm{E}-05$ & Oesophagus \\
\hline Stomach stem cell layer & $6.16 \mathrm{E}-04$ & $6.16 \mathrm{E}-04$ & St-stem \\
\hline Small intestine stem cell layer & $3.71 \mathrm{E}-03$ & $3.45 \mathrm{E}-03$ & SI-stem \\
\hline Right colon stem cell layer & $1.35 \mathrm{E}-03$ & $1.19 \mathrm{E}-03$ & RC-stem \\
\hline Left colon stem cell layer & $1.26 \mathrm{E}-03$ & $1.16 \mathrm{E}-03$ & LC-stem \\
\hline $\begin{array}{l}\text { Rectosigmoid Colon stem cell } \\
\text { layer }\end{array}$ & $7.59 \mathrm{E}-04$ & $6.99 \mathrm{E}-04$ & RS-stem \\
\hline ET1 basal cells & $2.00 \mathrm{E}-05$ & $1.70 \mathrm{E}-05$ & ET1-bas \\
\hline ET2 basal cells & $4.50 \mathrm{E}-04$ & $3.90 \mathrm{E}-04$ & ET2-bas \\
\hline Extra-thoracic lymph nodes & $1.60 \mathrm{E}-02$ & $1.27 \mathrm{E}-02$ & LN-ET \\
\hline Bronchi basal cells & $4.30 \mathrm{E}-04$ & $3.90 \mathrm{E}-04$ & Bronch-bas \\
\hline Bronchi secretary cells & $8.60 \mathrm{E}-04$ & $7.80 \mathrm{E}-04$ & Bronch-sec \\
\hline Bronchioles secretary cells & $1.90 \mathrm{E}-03$ & $1.90 \mathrm{E}-03$ & Bchiol-sec \\
\hline Alveolar interstitial & $1.10 \mathrm{E}+00$ & $9.04 \mathrm{E}-01$ & $\mathrm{AI}$ \\
\hline Thoracic lymph nodes & $1.60 \mathrm{E}-02$ & $1.27 \mathrm{E}-02$ & LN-Th \\
\hline Red (active) marrow & $1.39 E+00$ & $1.06 E+00$ & $R$-marrow \\
\hline Endosteal cells & $5.80 E-01$ & $4.33 E-01$ & Endost-BS \\
\hline Brain & $1.52 E+00$ & $1.35 E+00$ & Brain \\
\hline Lens of the eye & $4.00 \mathrm{E}-04$ & $4.00 \mathrm{E}-04$ & Eye-lens \\
\hline Pituitary gland & $6.28 \mathrm{E}-04$ & $6.18 \mathrm{E}-04$ & P-gland \\
\hline Tongue & 7.64E-02 & $6.19 \mathrm{E}-02$ & Tongue \\
\hline Tonsils & $3.14 \mathrm{E}-03$ & $3.09 \mathrm{E}-03$ & Tonsils \\
\hline Salivary glands & $8.90 \mathrm{E}-02$ & $7.22 \mathrm{E}-02$ & S-glands \\
\hline Thyroid & $2.34 E-02$ & $1.95 E-02$ & Thyroid \\
\hline Breast & $2.62 E-02$ & $5.15 E-01$ & Breast \\
\hline Thymus & $2.62 E-02$ & $2.06 E-02$ & Thymus \\
\hline Heart wall & $3.86 E-01$ & $2.91 E-01$ & Ht-wall \\
\hline Adrenals & $1.74 E-02$ & $1.55 E-02$ & Adrenals \\
\hline Liver & $2.36 E+00$ & $1.81 E+00$ & Liver \\
\hline Pancreas & $1.74 E-01$ & $1.45 E-01$ & Pancreas \\
\hline Kidneys & $4.22 E-01$ & $3.57 E-01$ & Kidneys \\
\hline Spleen & $2.284 E-01$ & $1.87 E-01$ & Spleen \\
\hline Gall bladder wall & $1.05 E-02$ & $8.25 E-03$ & GB-wall \\
\hline Ureters & $1.68 \mathrm{E}-02$ & $1.55 \mathrm{E}-02$ & Ureters \\
\hline
\end{tabular}




\begin{tabular}{lccr}
\hline Urinary bladder wall & $5.11 E-02$ & $4.08 E-02$ & UB-wall \\
\hline Ovaries & $0.00 E+00$ & $1.26 E-02$ & Ovaries \\
\hline Testes & $3.72 E-02$ & $0.00 E+00$ & Testes \\
\hline Prostate & $1.78 \mathrm{E}-02$ & $0.00 \mathrm{E}+00$ & Prostate \\
\hline Uterus & $0.00 E+00$ & $8.25 E-02$ & Uterus \\
\hline Systemic lymph nodes & $1.58 \mathrm{E}-01$ & $1.26 \mathrm{E}-01$ & LN-Sys \\
\hline Skin & $3.47 \mathrm{E}+00$ & $2.42 \mathrm{E}+00$ & Skin \\
\hline Adipose tissue & $1.75 \mathrm{E}+01$ & $2.18 \mathrm{E}+01$ & Adipose \\
\hline Muscle & $2.98 E+01$ & $1.79 E+01$ & Muscle
\end{tabular}

1 *Italicized rows correspond to target tissue regions listed in CEP/OLINDA compilation. 

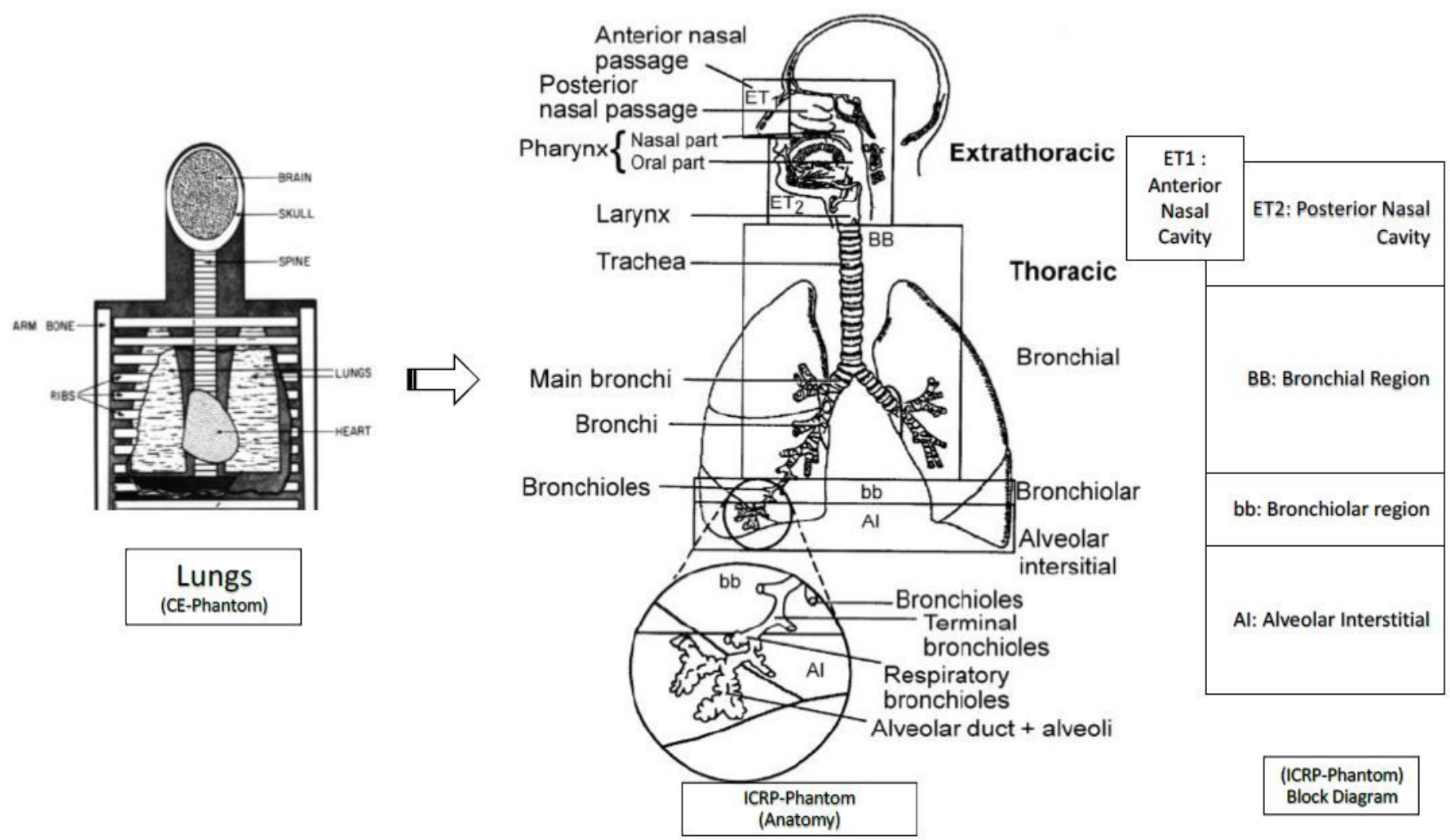

\section{Figure 1}

CE to ICRP transition for respiratory tract phantom geometry of source organs (figure adapted from ICRP publication 66 and [6]) 


\section{Source Regions - Respiratory Tract}

\section{ICRP Phantom}

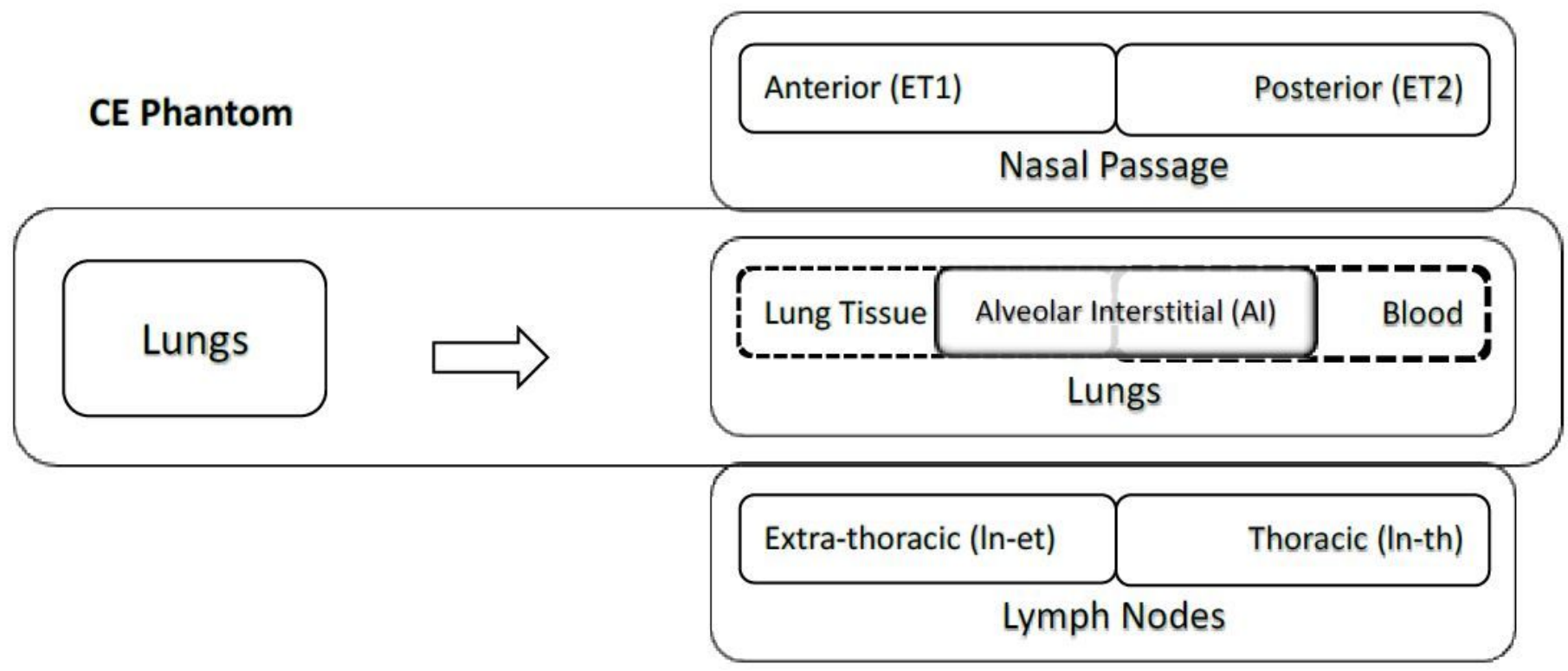

Figure 2

Simplified ICRP Respiratory tract phantom mapping CE source region for applications in diagnosis and therapy

\section{Target Regions - Respiratory Tract}

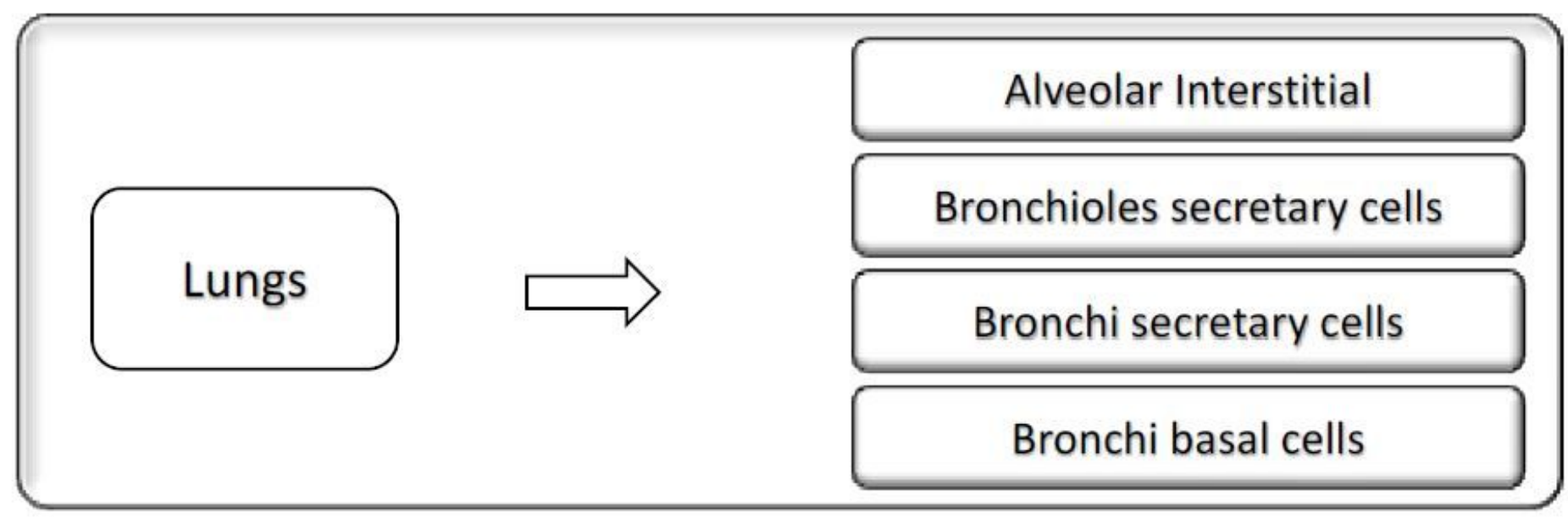

Figure 3

Target Tissue Mapping CE to ICRP 


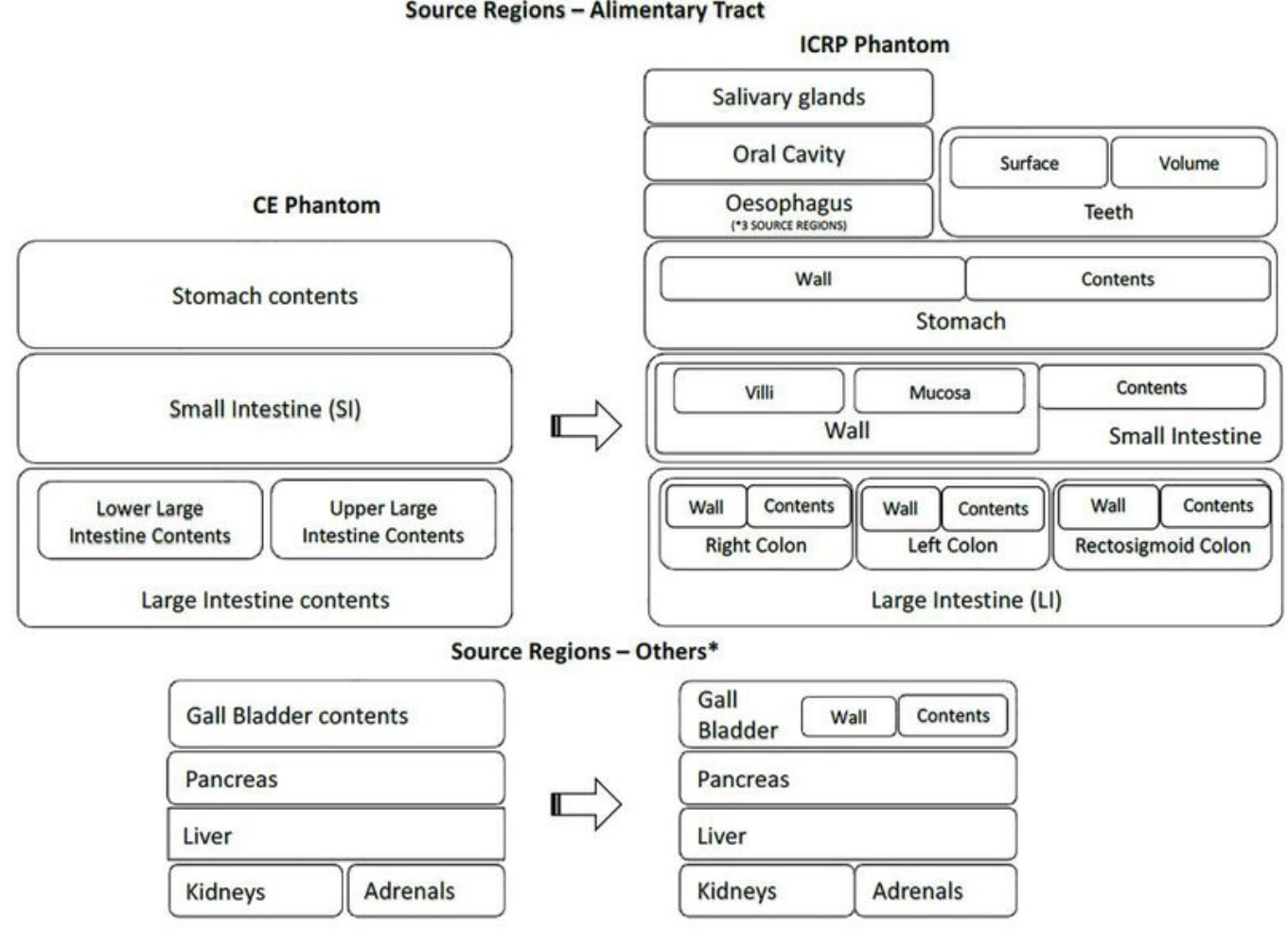

CE Phantom

Target Regions - Alimentary Tract

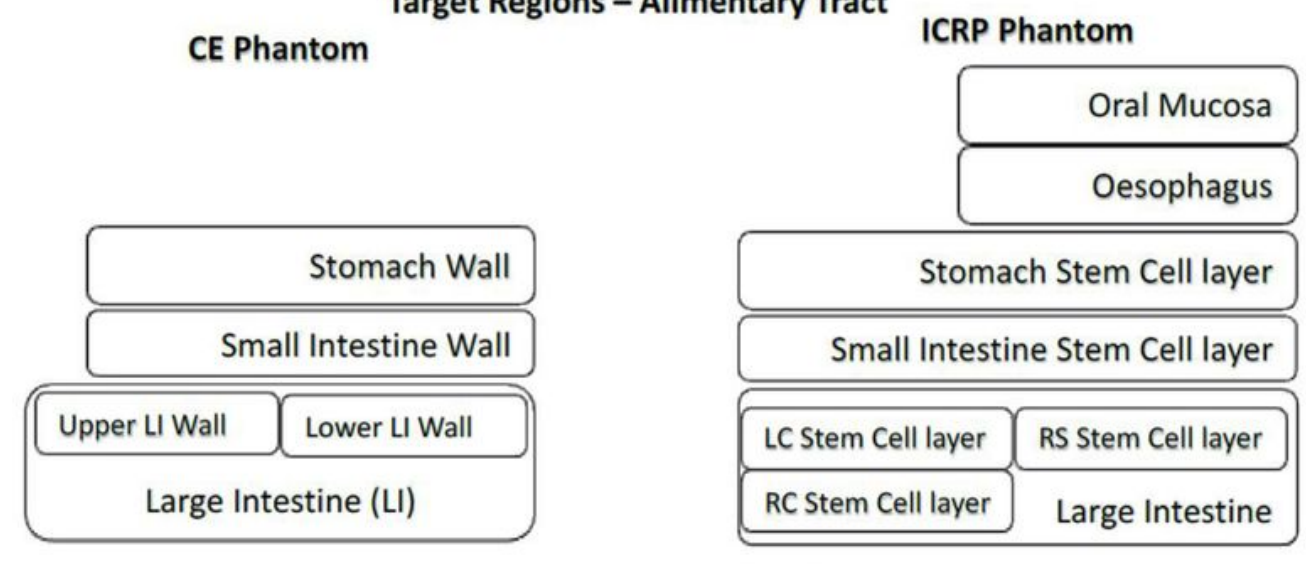

Target Regions - Others*

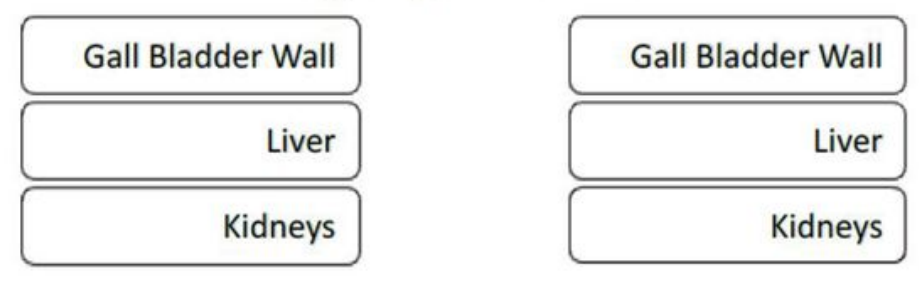

\section{Figure 4}

CE to ICRP transition in source regions for the alimentary tract. Regions that have not been redefined are included on both the CE and ICRP sides of the figure in separate boxes. ${ }^{*}$ Organs which indirectly contribute to the functioning of the alimentary tract. CEP to ICRP correspondence (target regions) for the alimentary tract. * Organs which indirectly contribute to the functioning of the alimentary tract 
Source Regions - Skeletal System

CE Phantom

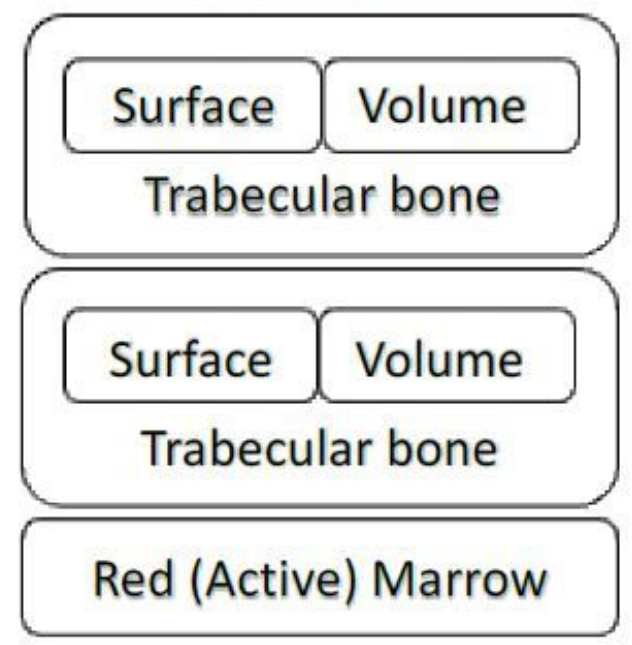

ICRP Phantom

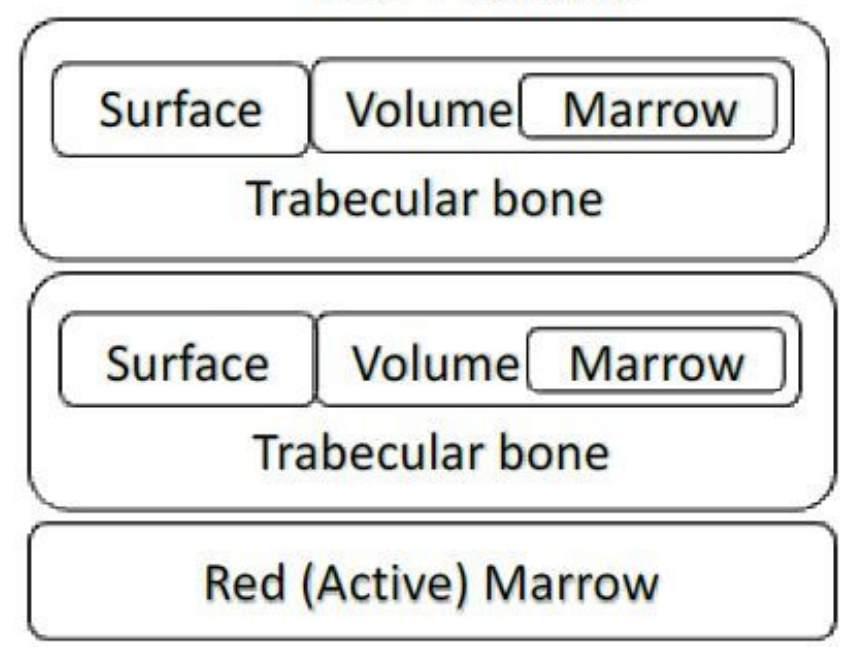

Yellow (Inactive) Marrow

\section{Target Regions}

\section{Osteogenic Cells}

Red (Active) Marrow
Endosteal bone surface

Red (Active) Marrow

Figure 5

CE Phantom to ICRP phantom mapping in Skeletal system 


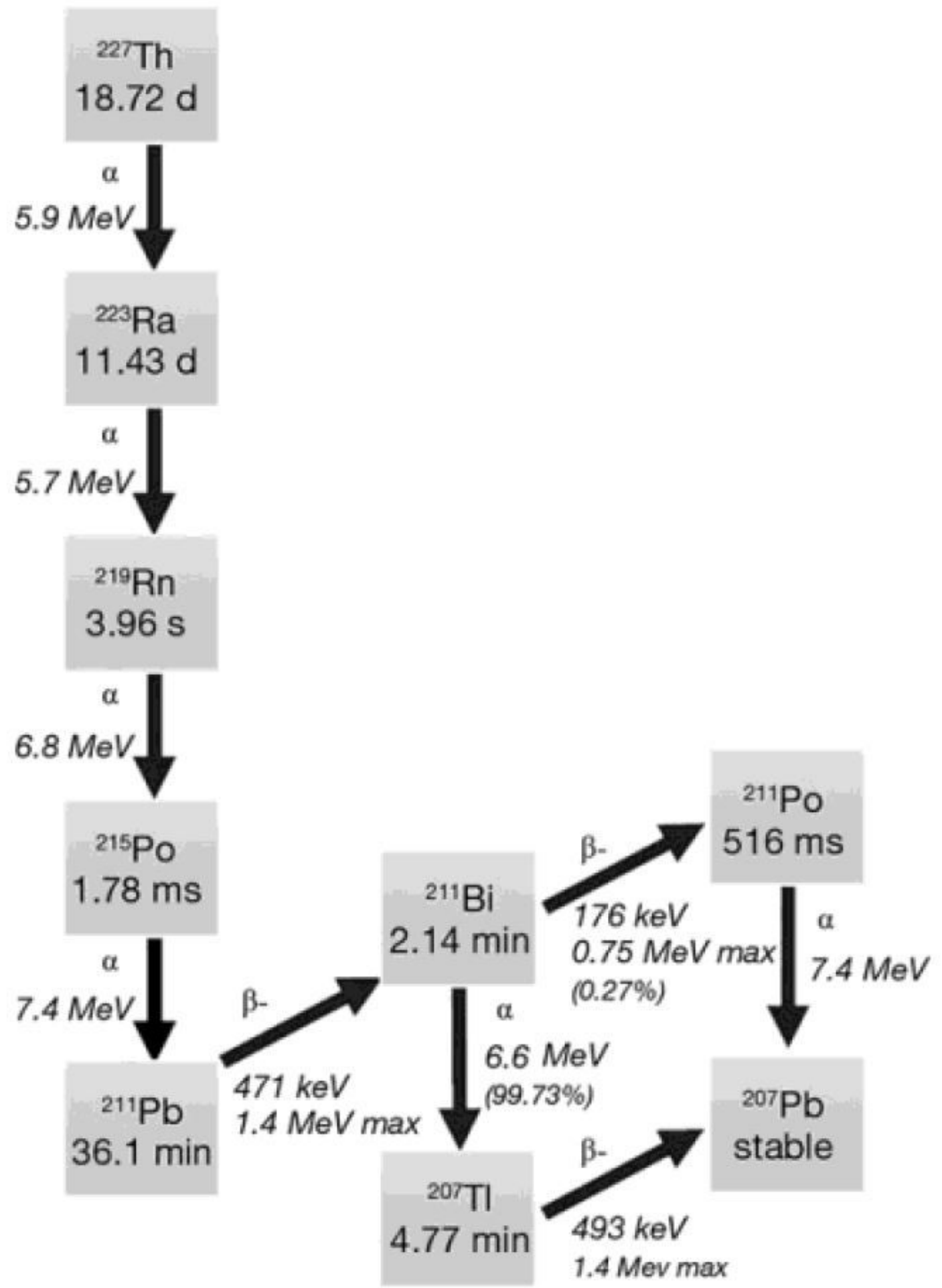

Figure 6

Decay scheme of thorium-227 
Photon Absorbed Doses (Thorium-227 + daughters) (mGy/kBq)

0.005

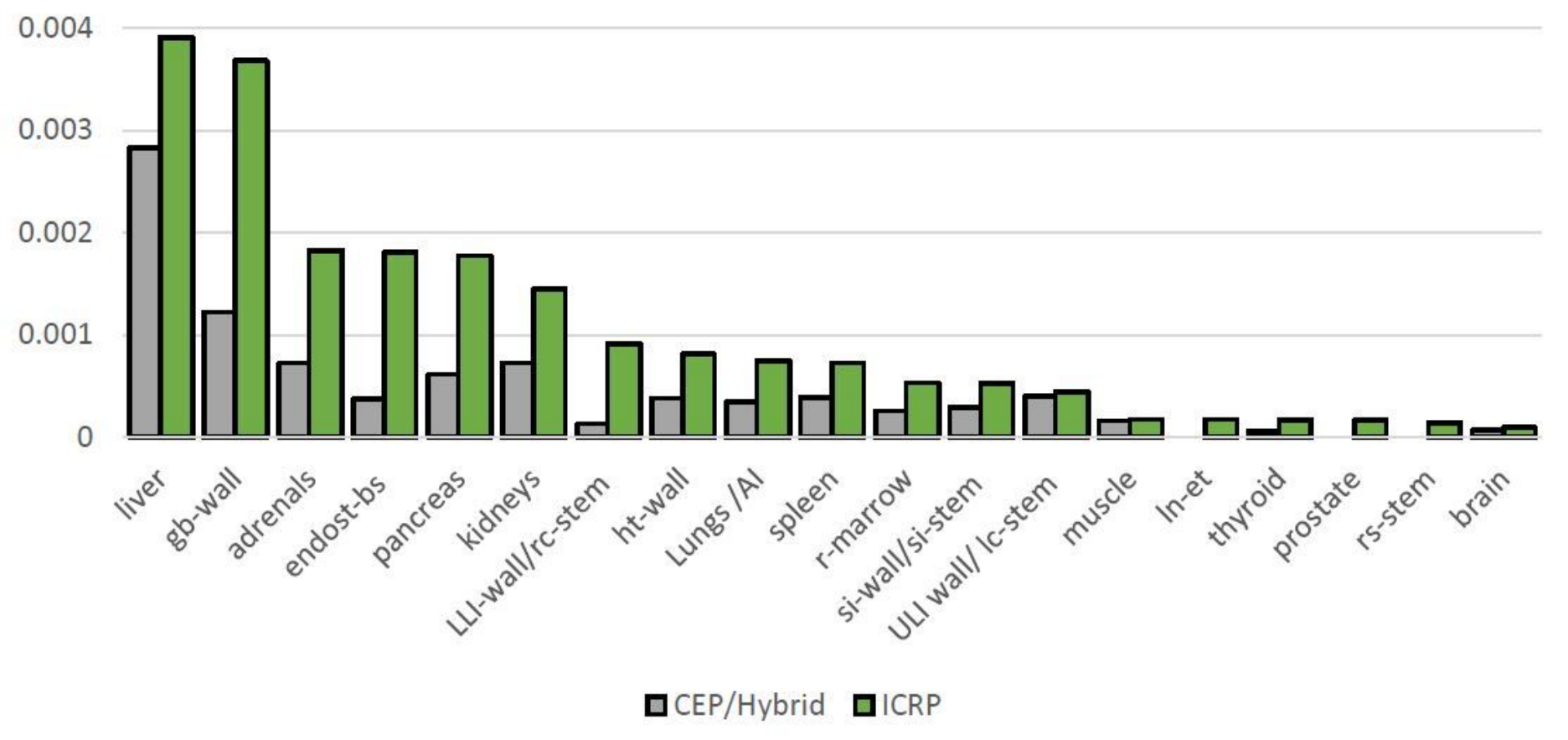

Figure 7

Comparison between photon doses computed from CEP, Hybrid and ICRP 


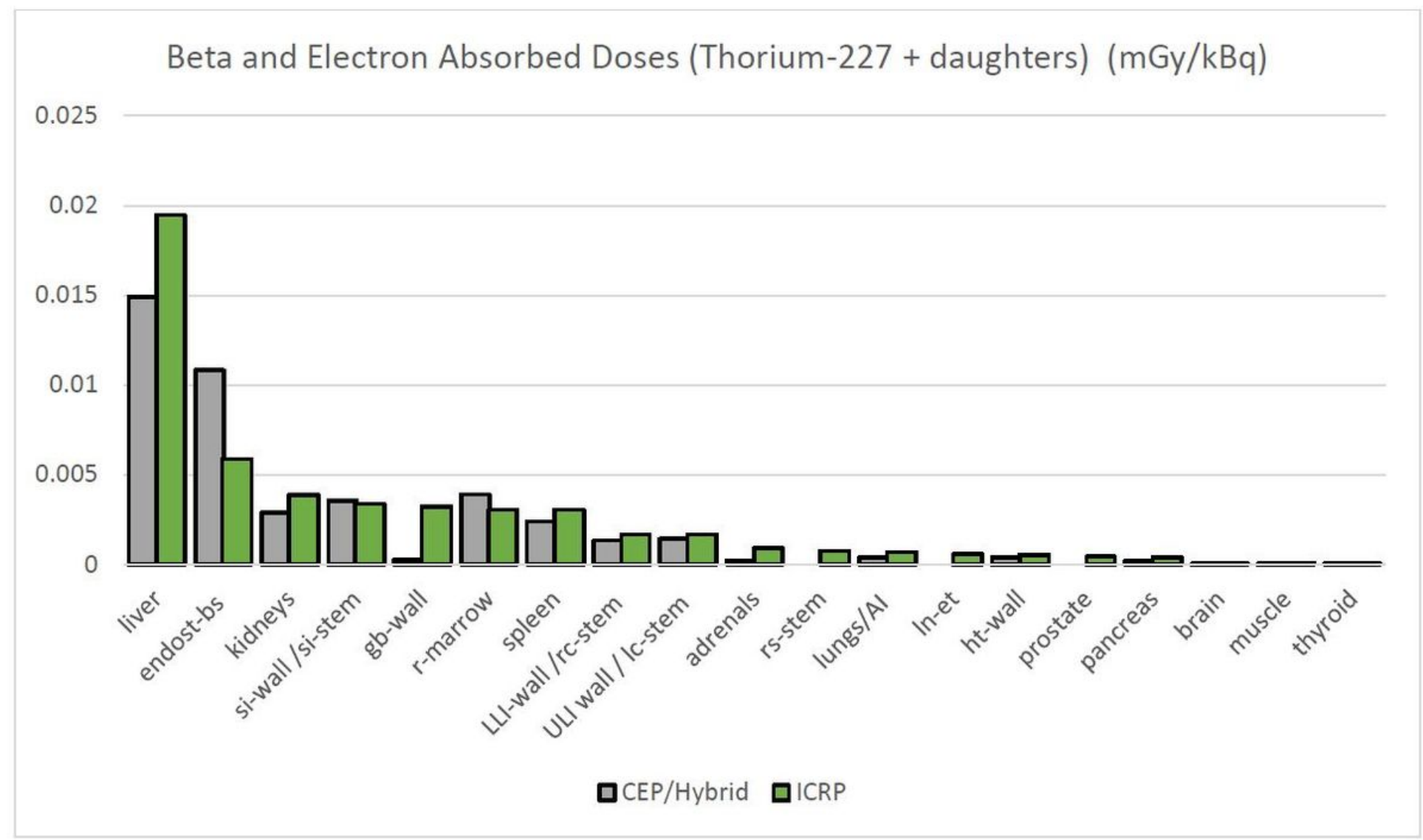

\section{Figure 8}

Comparison between the sum of beta-particle and electron absorbed doses calculated using the CEP, Hybrid and ICRP methods. 


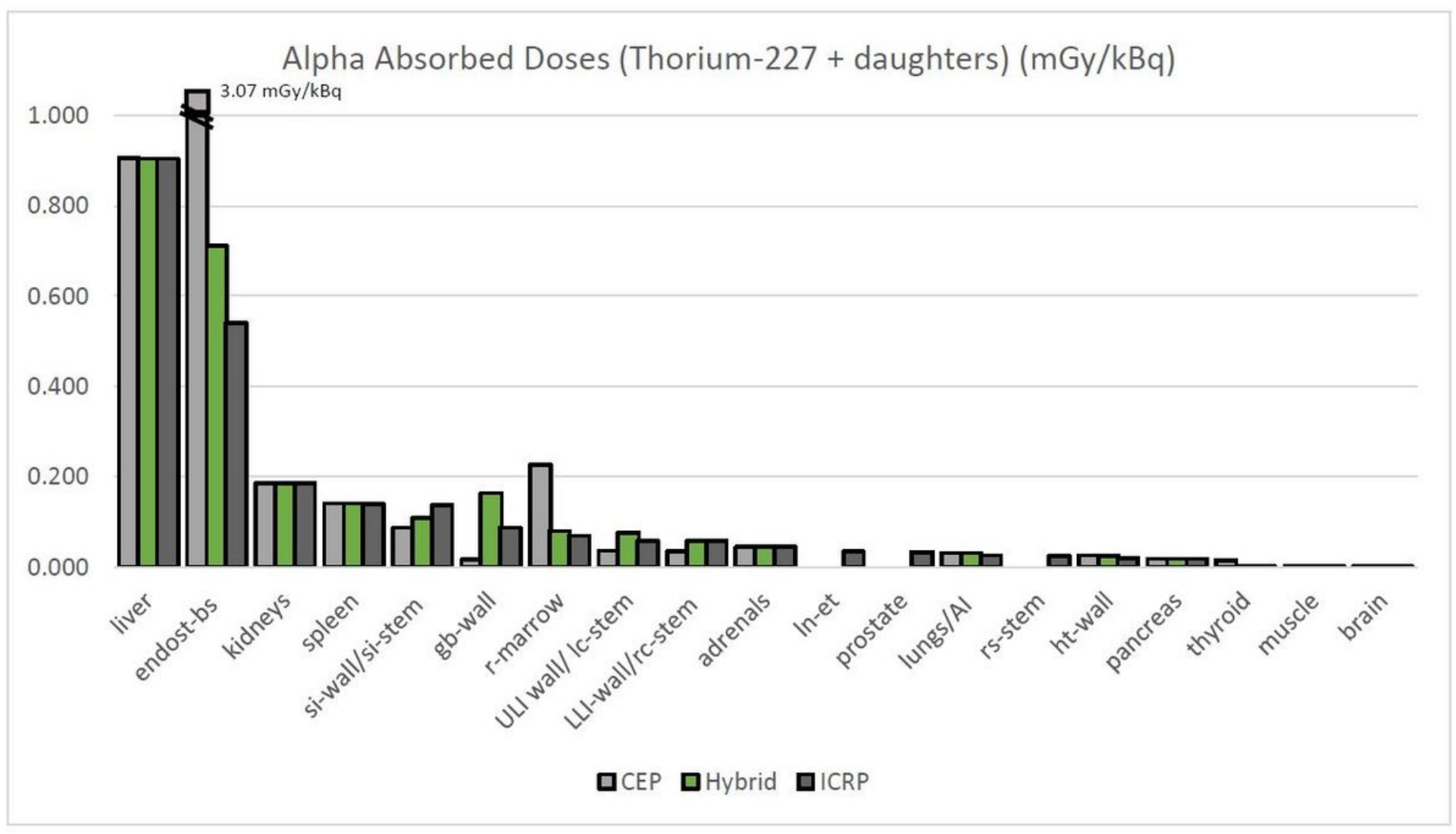

Figure 9

Alpha particle absorbed dose comparisons across CEP (calculated using OLINDA), Hybrid, and ICRP

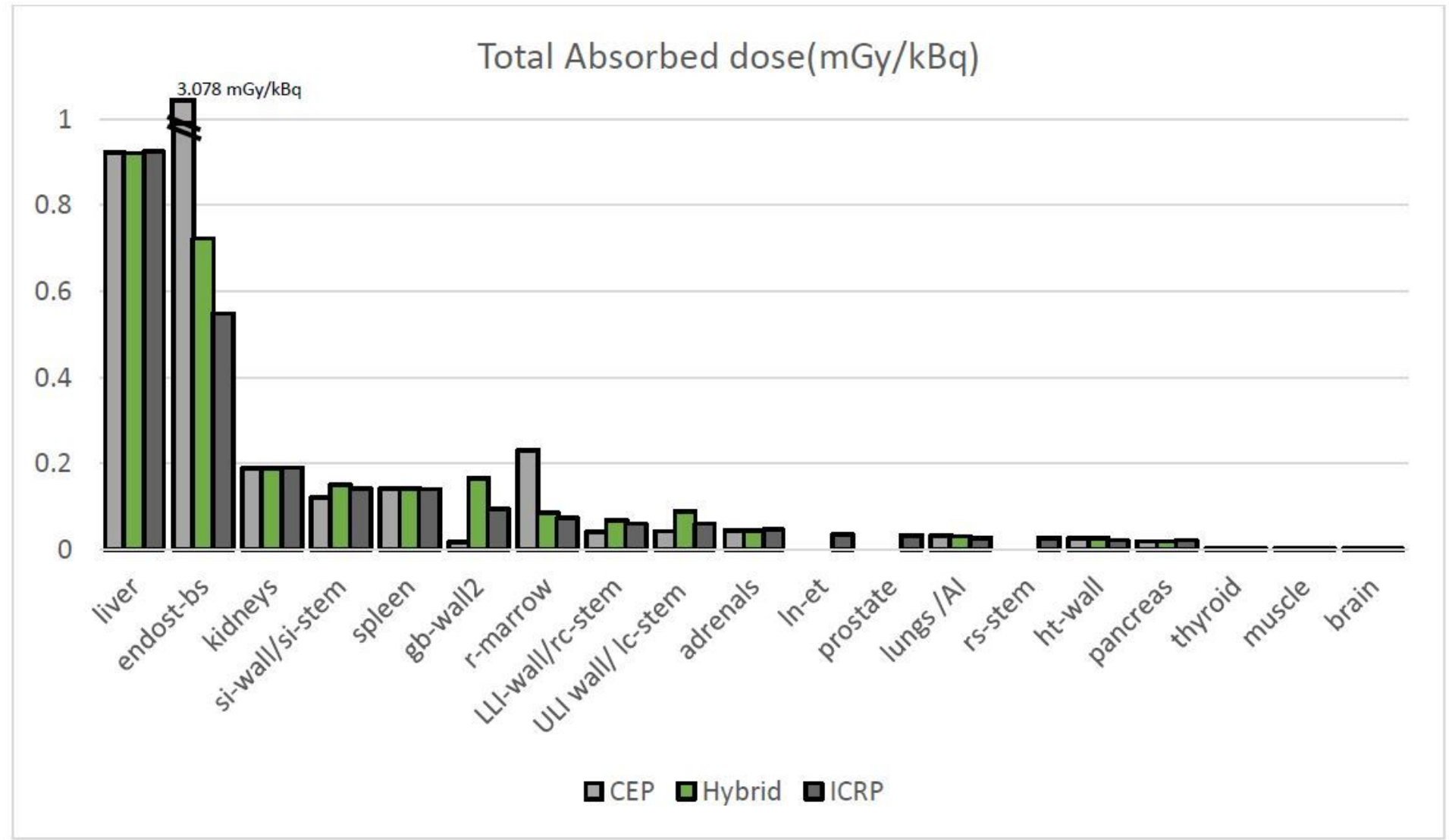


Figure 10

Total Specific Absorbed Doses calculated using CEP, Hybrid and ICRP

A

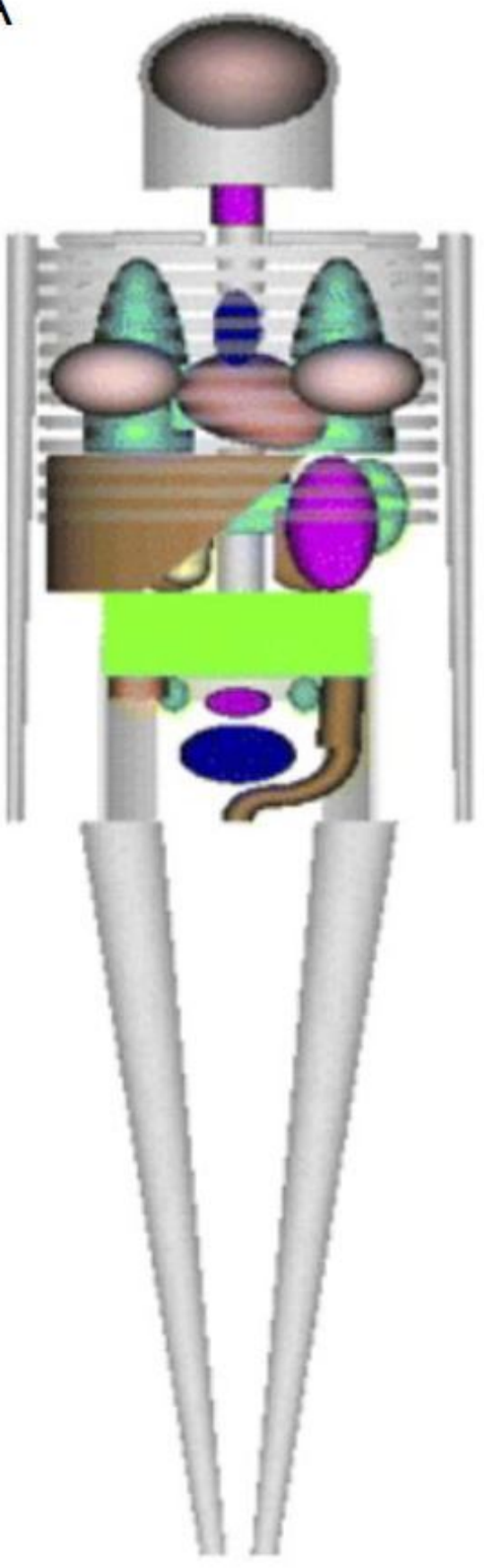

B

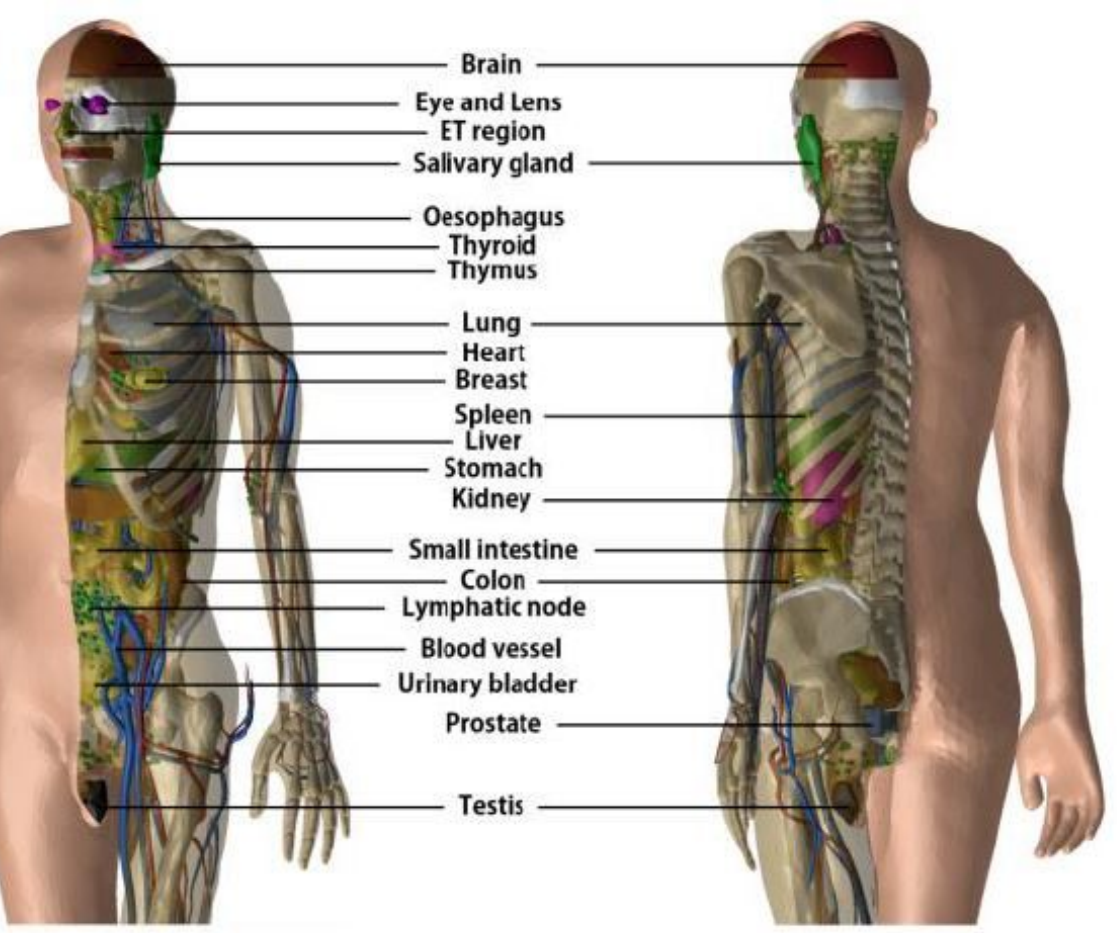

C

C

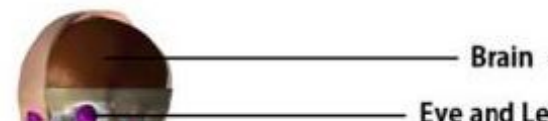
Salivary gland

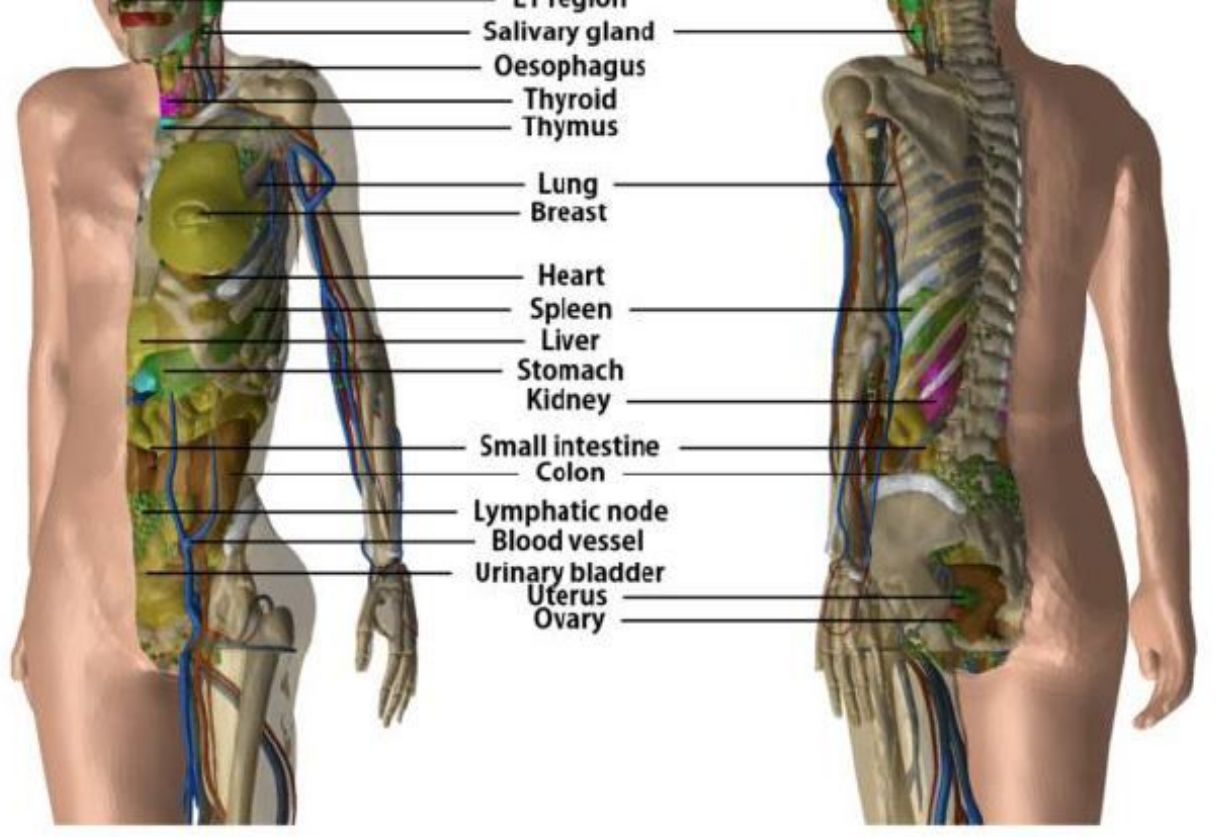

\section{Figure 11}

Representation of (A) the CE phantom (from www.doseinfo-radar.com) and (B) the mesh version of ICRP 110 voxelized reference adult male phantom (C) the mesh version of ICRP 110 voxelized reference adult 
female phantom [18][21]

SKELETAL AVERAGED ABSORBED FRACTIONS

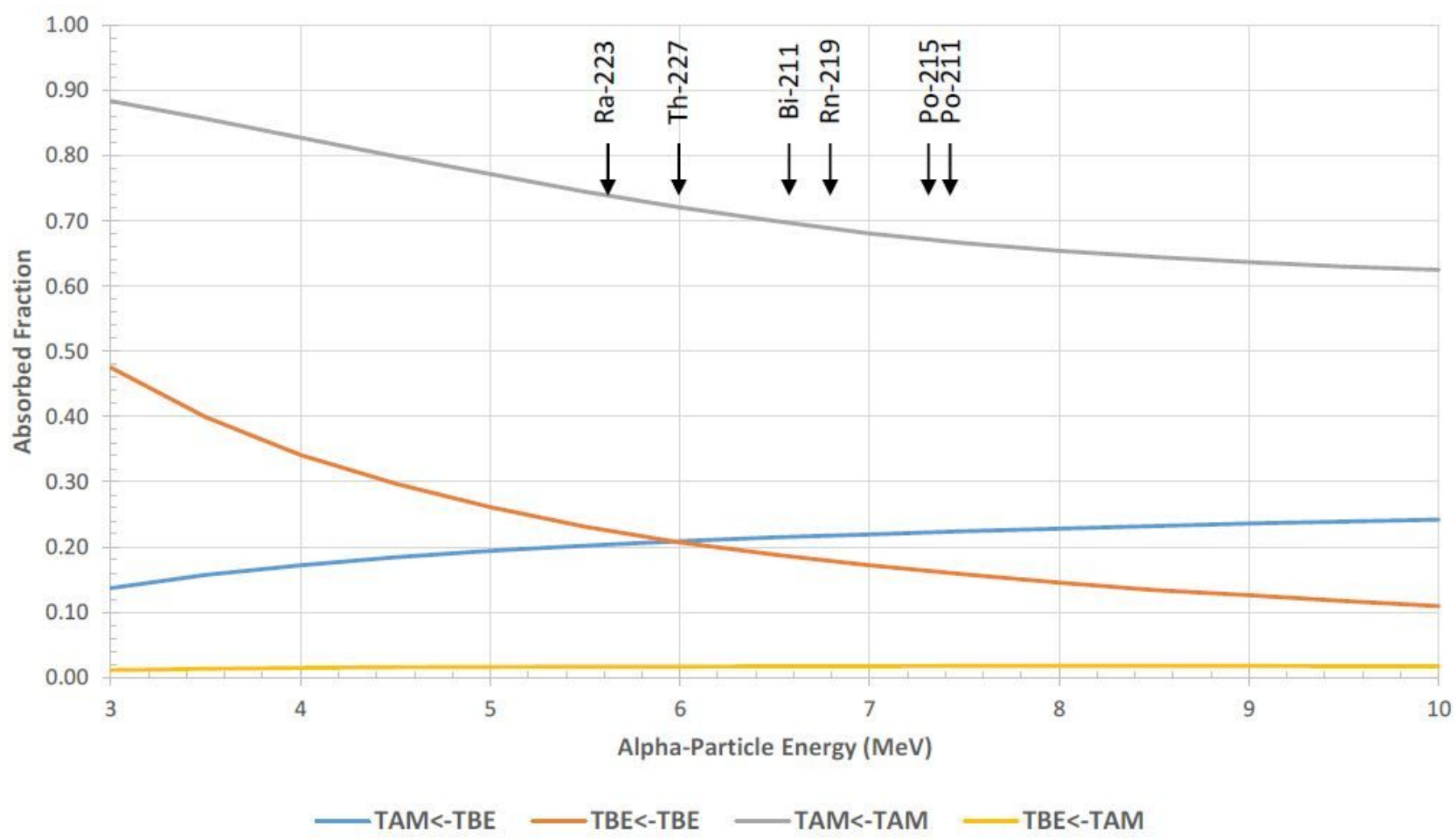

Figure 12

Absorbed fraction vs alpha-particle energy. The figure shows that the self-dose absorbed fractions (TAM $\triangle T A M$ ) are less than 1 and the cross dose absorbed fractions (TAM $\triangle \mathrm{TBE}$ ) are less than 0.5 The energy of alpha particles (with a yield greater than 20\%) and corresponding alpha emitters is shown by arrows. TAM <- Trabecular Active Marrow, TBE <- Trabecular Bone Endosteum. 